
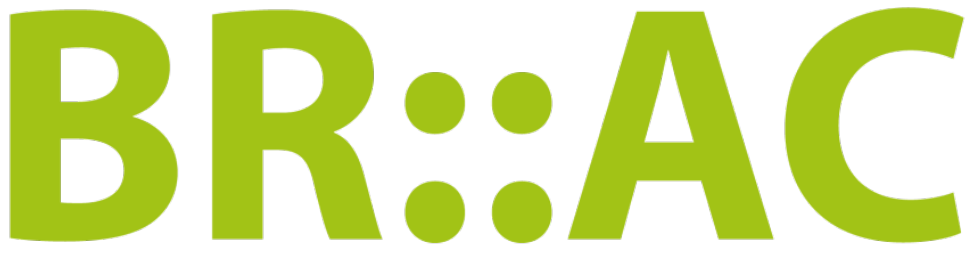

Barcelona Research

Art

Creation

\title{
Volume 2, Number 2
}

\section{Hipatia Press \\ www.hipatiapress.com}

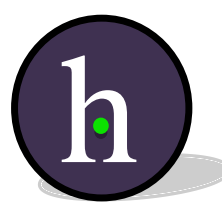

Sentido y Responsabilidad: Una Perspectiva Bioética sobre la Creación, Mutación e Hibridación Experimental en el Campo Interdisciplinar de la Tecnociencia y el Arte-

Laura Baigorri

Articles

José Luis Guerin: Descubriendo una Sintaxis Posible-

Juan M. Villegas

Génesis del Arte Minimalista: Aportación Mexicana -

Pablo Estévez

La página ideal de Sol LeWitt -

Eugènia Agustí

Reviews Dibuixar un arbre d'Àlex Nogué-

Rosa Pera Roca 
Instructions for authors, subscriptions and further details:

http://brac.hipatiapress.com

\section{Sentido y Responsabilidad: Una Perspectiva Bioética sobre la Creación, Mutación e Hibridación Experimental en el Campo Interdisciplinar de la Tecnociencia y el Arte}

Laura Baigorri ${ }^{1}$

1) Universidad de Barcelona. España

Date of publication: June $3^{\text {rd }}, 2014$

Edition period: February 2014-June 2014

To cite this article: Baigorri, L. (2014). Sentido y responsabilidad: Una perspectiva bioética sobre la creación, mutación e hibridación experimental en el campo interdisciplinar de la tecnociencia y el arte. Barcelona, Research, Art, Creation, 2(2), 137-168. doi: 10.4471/brac.2014.07

To link this article: http://dx.doi.org/10.4471/brac.2014.07

\section{PLEASE SCROLL DOWN FOR ARTICLE}

The terms and conditions of use, except where otherwise noted, are related to the Open Journal System and to Creative Commons Attribution License (CCBY). The indication must be expressly stated when necessary. 
BRAC - Barcelona Research Art Creation. Vol. 2 No. 2, June 2014, pp. 137-168

\title{
Sense and Responsibility: A Bioethical Perspective on Experimental Creation, Mutation and Hybridization in the Interdisciplinary Field of Technoscience and Art
}

Laura Baigorri

University of Barcelona

(Received: 5 September 2013; Accepted: 10 March 2014; Published: 3 June 2014)

\begin{abstract}
Only humans have created a technoscience able to delete our own kind, and all others, from the face of the earth and if, as affirm the philosopher Hans Jonas, the responsibility is a correlate of the power, the magnitude of power must determine the magnitude of the responsibility. In the last decade, many artists have begun to work in the border areas of science and technology considering the need for a critical analysis in this field developed from extra-medical or extra-industrials criteria. This article examines the works of artists, made under bioart parameters, that impact particularly in the ethical sense of human behaviour toward animals and living things in general. Most projects have been developed in scientific laboratories and have to do with the creation (generation of life), genetic mutation and hybridization, and the symbiotic relationships between animals and humans. Through them, the artists demonstrate their sense of responsibility and their ability to assume the consequences of their creations with the aim to open new ethical debates about science.
\end{abstract}

Keywords: Bioethics, bioart, transgenic art, genetic mutation and hybridization, relationship human/animal. 
BRAC - Barcelona Research Art Creation. Vol. 2 No. 2, June 2014, pp. 137-168

\title{
Sentido y Responsabilidad: Una Perspectiva Bioética sobre la Creación, Mutación e Hibridación Experimental en el Campo Interdisciplinar de la Tecnociencia y el Arte
}

\author{
Laura Baigorri \\ Universidad de Barcelona
}

(Recibido: 5 Septiembre 2013; Aceptado: 10 Marzo 2014; Publicado: 3 Junio 2014)

\section{Resumen}

Sólo los humanos hemos creado una tecnociencia capaz de borrar a nuestra propia especie, y a todas las demás, de la faz de la Tierra y si, como afirma el filósofo Hans Jonas, la responsabilidad es un correlato del poder, la magnitud del poder debe determinar la magnitud de la responsabilidad. En la última década, numerosos artistas han comenzado a trabajar en las zonas fronterizas de la ciencia y la tecnología planteando la necesidad de un análisis crítico en este campo desarrollado a partir de criterios extra-médicos o extra-industriales. Este texto analiza trabajos de artistas, realizados bajo los parámetros del bioarte, que inciden particularmente en el sentido ético de la conducta humana hacia los animales y los seres vivos en general. La mayoría de proyectos han sido desarrollados en laboratorios científicos y tienen que ver con la creación (generación de vida), la mutación e hibridación genética, y con las simbióticas relaciones entre animales e humanos. A través de ellos, los artistas demuestran su sentido de la responsabilidad y su capacidad para asumir las consecuencias de sus creaciones con el objetivo abrir nuevos debates éticos sobre la ciencia.

Palabras clave: Bioética, bioarte, arte transgénico, mutación e hibridación genética, relaciones animal/humano.

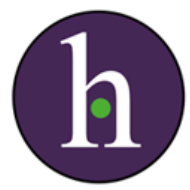


Responsabilidad es el cuidado, reconocido como deber, por otro ser, cuidado que, dada la amenaza de su vulnerabilidad, se convierte en “preocupación”. (Jonas, 1979)

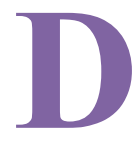

\section{el poder y la ética: el ser humano creador y dominador de la} naturaleza. La condición humana está indisolublemente ligada a la consciencia y la responsabilidad. Somos responsables de nosotros mismos, de nuestros hijos, de nuestra especie y del resto de especies que habitan el ecosistema. Sólo los humanos hemos creado una tecnociencia capaz de borrar a nuestra propia especie y a todas las demás de la faz de la Tierra y si, como afirma el filósofo Hans Jonas, la responsabilidad es un correlato del poder, la magnitud del poder determina la magnitud de la responsabilidad. Los humanos poseemos y gestionamos el mundo y, por lo tanto, somos los máximos garantes de su bienestar y destino. Por supuesto, sufrimos amnesia intermitente.

Las relaciones entre humanos y animales distan mucho de aproximarse a las relaciones de biopoder -ese término acuñado por Foucault para referirse a las prácticas de control de la población por parte de los estados- pues, antes que en el poder, se basan en la dominación absoluta de los primeros hacia los segundos.

Una relación de poder se articula sobre dos elementos que son indispensables para ser precisamente una relación de poder: que "el otro" (aquél sobre el que se ejerce la relación) sea reconocido y mantenido hasta el final como sujeto de acción; y que se abra, ante la relación de poder, todo un campo de respuestas, reacciones, efectos, invenciones posibles. (Foucault, 1984)

La relación entre amo y esclavo es una relación de poder porque existe la posibilidad de huida pero, en su interacción con los humanos, los animales no tienen posibilidad de transformar su situación, están atrapados en una relación asimétrica e irreversible que depende exclusivamente de la ética de sus dominadores.

En el capítulo primero del Génesis, Dios concedía al hombre el control 
y dominio sobre todos los animales y éste no ha dudado en utilizarlos en su beneficio a lo largo de los siglos: para comer, para trabajar, para protegerse, para divertirse, para sentirse acompañado, para experimentar médicamente.... Desde nuestra visión antropocéntrica dominante somos la medida de todas las cosas y nuestros intereses se encuentran por encima de todo lo demás. No obstante, poder y dominio implican responsabilidad; entonces, ¿cuáles son los límites de nuestra responsabilidad?, o expresado de forma aristotélica, ¿debemos hacer todo aquello que podemos hacer? Esta es una de las principales preguntas que plantean los artistas que trabajan en las fronteras de la tecnociencia y el arte.

Haciendo uso del poder absoluto otorgado por Dios -y amplificado después si cabe por la tecnología y la ciencia-, el artista Eduardo Kac “jugó a ser dios" en la obra Genesis (1999). El proyecto consistió en crear un gen sintético que no existía en la naturaleza y para ello insertó dentro de una bacteria un fragmento de $\mathrm{ADN}$ cuya secuencia es precisamente una traducción del pasaje de la Biblia donde Dios concede al hombre el control sobre la naturaleza: "Let man have dominion over the fish of the sea, and over the fowl of the air, and over everything that moves upon the earth" (Génesis, 1.26 28). El gen se creó traduciendo esta frase en código Morse y convirtiendo el código en una base de pares de ADN siguiendo un principio de conversión específico para este trabajo. La obra se presentó como una instalación con conexión online en el Centro Ars Electronica de Linz, de manera que, cuando los participantes remotos se conectaban al proyecto, encendían una luz ultra violeta y la bacteria contenida en una caja de Petri respondía emitiendo una luz visible (cian y amarilla). Con Genesis, Kac estaba "explorando la intrincada relación entre la biología, religión, la tecnología de la información, la interacción dialógica, ética e Internet", pero también proponía una paradoja genial: la nueva obra de materia viva se había creado a partir de las palabras concretas de Dios dándole poder al hombre sobre todos los seres vivos del planeta y aludiendo, a su vez, a la frase de los evangelios: "Y la Palabra se hizo carne y habitó entre nosotros" (Juan 1,14). 


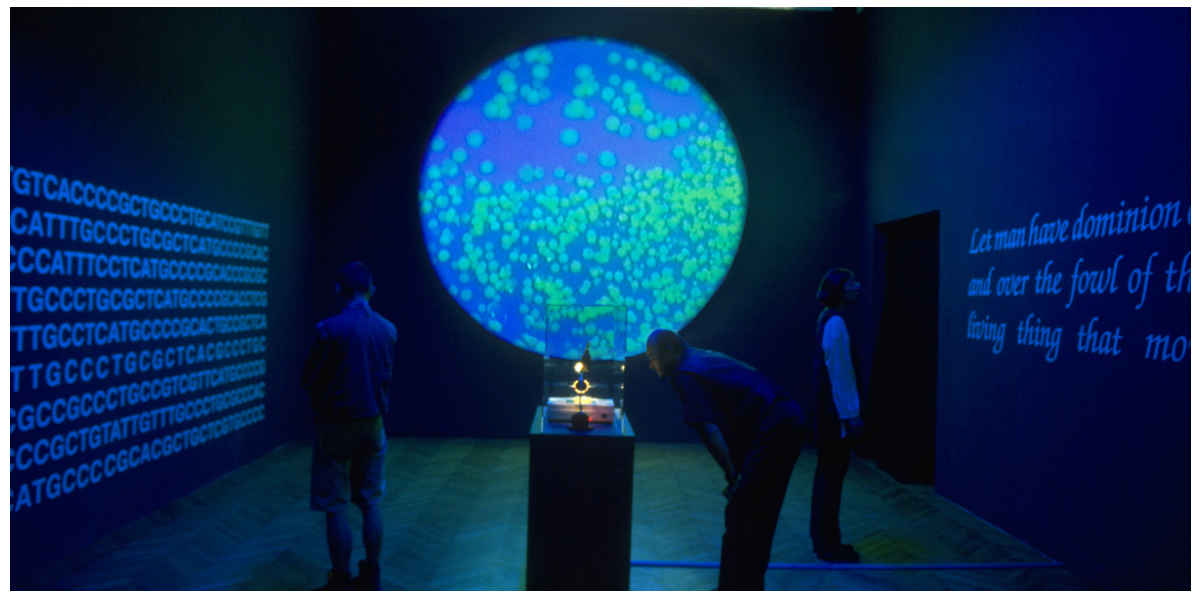

Figura 1. Eduardo Kac, Genesis, 1999. Obra transgénica con bacterias creadas por el artista, luz ultravioleta, internet, vídeo (detalle), edición de 2, dimensiones variables. Colección Instituto Valenciano de Arte Moderno (IVAM), Valencia, España. Foto: Otto Saxinger. Cortesía del artista. (C)

En 1997, Kac acuñó el término de Bioarte para referirse a una práctica artística donde los seres humanos trabajan con tejidos, bacterias y organismos vivos utilizando procesos científicos como la biotecnología. Y en 1998 proponía el concepto de arte transgénico, definido como "una nueva forma de arte basada en el uso de las técnicas de ingeniería genética para transferir material de una especie a otra, o de crear unos singulares organismos vivientes con genes sintéticos". Pero de inmediato lo vinculaba al ejercicio de la responsabilidad:

La naturaleza de este nuevo arte no sólo es definida por el nacimiento y el crecimiento de una nueva planta o un nuevo animal sino, sobre todo, por la naturaleza de relación entre el artista, el público y el organismo transgénico. (...) No hay arte transgénico sin un compromiso firme y la aceptación de la responsabilidad por la nueva forma de vida creada así. Las preocupaciones éticas son de capital importancia en cualquier obra artística y se hacen todavía más cruciales que nunca en el contexto del arte biológico, donde un ser vivo real es la propia obra de arte. (Kac, 1998)

Desde finales de los 90, Kac plantea su trabajo como reflexiones que imprimen un giro ético y estético a los axiomas conocidos; por esta razón, 


\title{
142 Baigorri-Sentido y Responsabilidad: una perspectiva bioética
}

se podría decir que, antes que un simple artista, Eduardo Kac es un filósofopoeta que utiliza el arte para expresar sus pensamientos e ideas.

Unos años antes, entre las obras pioneras del arte de Internet, ya habían aparecido las primeras tentativas de creación y manipulación de vida vinculadas al ejercicio de la responsabilidad, tanto con vida vegetal -Ken Goldberg y The Telegarden (1995-2004)-, como con vida animal -Netband y The Egg of Internet (1995)-. La primera experiencia permitía a los usuarios de la red cultivar su propio jardín a distancia y fue muy popular durante casi una década. El segundo proyecto, sin embargo, fue una obra inconclusa que surgió en Desk.nl ese mismo año; su promotor fue el artista austríaco afincado en Ámsterdam, Franz Feigl, quien reunió a varios artistas e intelectuales interesados en el proyecto bajo el nombre de Netband. Como parte de Desk. nl, el artista Mariano Maturana estuvo colaborando en la construcción de una incubadora provista de una cámara de vídeo que podía registrar en directo el proceso de crecimiento del huevo y explica así cuales eran las premisas de este experimento:

\begin{abstract}
A través de una interface incrustada en el navegador Netscape, los usuarios se podían registrar para tener acceso a la imagen de la cámara en directo, pero al mismo tiempo, sin saberlo, interactuaban con la incubadora generando el calor suficiente para hacer posible que el huevo comenzara su proceso de vida. De esta manera, a mayor cantidad de visitantes, mayor era la cantidad de calor que aseguraba este proceso. Una vez nacido el pollito era necesario alimentarlo y esta actividad era responsabilidad de los usuarios mismos que debían volver al sitio web para interactuar con un sistema que le daba de comer y de beber. La vida del pollito dependía entonces de los usuarios que le habían dado vida. (Entrevista personal en agosto de 2013)
\end{abstract}

En 2011, la artista argentina Marina Zerbarini iniciaba un proceso similar con su obra Síntesis simbiótica entre una máquina y un ser vivo (2011-2013). El 29 de enero de ese año colocó en el Espacio Fundación Telefónica de Buenos Aires tres incubadoras artificiales que incorporaban electrónicamente la luz, el calor y la humedad necesarios para la gestación de huevos fértiles, de tal forma que el proceso podía seguirse en Internet a través de una cámara. En una de ellas se realizaba la gestación, en otra el nacimiento y en la última la alimentación de las aves. La principal intención de Zerbarini era destacar un punto de vista opuesto a intereses industriales y comerciales en este tipo de 
actividades, mostrando las posibilidades de la tecnología para cuidar a estos pequeños seres vivos.

En los dos casos los objetivos eran similares: establecer un sistema cooperativo voluntario que dotase de responsabilidad al ser humano para que, a través de la tecnología, fuese capaz de generar, mantener y cuidar la vida animal. Pero los proyectos de las incubadoras no han acabado de funcionar por problemas técnicos: The Egg of Internet, debido al reducido ancho de banda que tenían los servidores de la época, puesto que el tráfico que generaban las interacciones de los usuarios colapsaba los escasos $2 \mathrm{MB}$ que entonces permitía el servicio de telefonía holandesa. Y Síntesis simbiótica entre una máquina y un ser vivo porque, aunque el volumen de tráfico en Internet siempre fue potente y fluido, surgieron problemas de falta de aireación en las incubadoras, siendo definitiva la dificultad de control del sistema durante los fines de semana, cuando el centro estaba cerrado. Las buenas intenciones de la colectividad artística no han podido superar el delicado equilibrio entre genética y técnica que requerían los pollitos en las incubadoras. La vida animal es muy frágil... y los humanos manejamos demasiadas variables cuando operamos como colectivo espontáneo; unas veces es el insuficiente control sobre la tecnología y otras nuestra inconstancia y falta de previsión. Parece ser que los proyectos que implican a seres vivos no se pueden dejar en manos del azaroso destino que pueda determinar un colectivo anónimo porque los humanos todavía no sabemos manejar la responsabilidad compartida. (A finales de 2013, y tras 5 experiencias anteriores fallidas, Zerbarini consiguió que nacieran 24 pollitos en su casa, pero sin intervención de terceros. Una vez controladas la temperatura y humedad necesarias, la artista persiste en su intento colectivo).

\section{Mutación genética y cría selectiva: cuando los artistas se apropian de prácticas ajenas}

Si modificar el ADN de las células o ayudar a nacer a pollitos pudieran ser considerados experimentos de baja intensidad en la escala de la ingeniería genética (aunque no en el territorio del arte), el siguiente paso en complejidad se encuentra en la mutación y cría selectiva de animales cotidianos, tales como mariposas, peces y conejos.

La artista portuguesa Marta de Menezes viene dedicándose durante más de una década a la creación de obras vivas a través de la experimentación 


\section{Baigorri-Sentido y Responsabilidad: una perspectiva bioética}

genética con animales. En Nature? (1999-2000) trabajó junto al biólogo Paul Brakefield con las larvas de mariposas Bicyclus anynana y Heliconius Melpómene para modificar los patrones de sus alas con fines artísticos, consiguiendo inducir, mediante injertos naturales, un nuevo patrón que antes no existía en la naturaleza.

La intervención artística deja los genes de la mariposa sin cambios, de manera que los nuevos patrones no se transmiten modificados a la descendencia de las mariposas; simplemente desaparecen de la naturaleza sin dejar rastro. Estas obras de arte, literalmente, viven y mueren. Son un ejemplo de arte con una esperanza de vida limitada, la vida de una mariposa. (Menezes, 2003)

El interrogante del título hace referencia al desarrollo completamente natural de las alas, pero como paradójico resultado de la intervención humana. Para Menezes, esta obra cuestiona las similitudes y las diferencias entre lo natural y "lo nuevo natural", evidenciando la posibilidad de reinventar la naturaleza a través de la ciencia, pero asumiendo las consecuencias y sin dañar el ecosistema. Ante este tipo de proyectos algunos se preguntarán ¿pero qué derecho tienen los artistas a crear o mutar genéticamente a los seres vivos? A lo cual podríamos responder con otra pregunta irealmente el problema es que sean los artistas quienes lo hacen?, ¿el principal inconveniente es que la manipulación se establezca desde el mundo del arte y/o esté orientado a un supuesto resultado estético? De acuerdo, el utilitarismo es una excusa para muchos, ya que la finalidad de la experimentación científico-médica con animales es curar enfermedades humanas y de la agraria, la industria de la alimentación. Pero a veces olvidamos que existe una milenaria tradición en la cría selectiva de especies animales, una de cuyas principales funciones es el disfrute estético ${ }^{1}$.

En 1998, Eduardo Kac ya había iniciado la prefiguración de uno de sus proyectos más conocidos -y sin duda el más polémico- proponiendo mutar genéticamente un perro "xolo" mexicano (Xoloitzcuintle),... para que después fuese adoptado por su propia familia.

Pero GFP K-9 (1998) nunca se pudo llevar a cabo porque, a pesar de que la manipulación genética de razas caninas sea una práctica habitual, las leyes y protocolos de laboratorio no permiten trabajar con perros para estos fines. Entonces el artista decidió continuar con el proyecto a partir de un animal de laboratorio “autorizado" y así surgió GFP Bunny (2000), una conejita mutada con un gen de ameba que se muestra de color verde fluorescente sólo cuando 
se ilumina con luz azul. Es importante remarcar aquí que esta característica era completamente inocua para el animal y no le comportaba ninguna secuela física, ni a corto ni a largo plazo. Como asegura el artista, el proyecto no fue nunca "la obra de arte de un conejo verde", sino que comprendía la creación de un conejo verde fluorescente, el diálogo público generado por el proyecto y la integración social del conejo; es decir, un work in progress cuyas fases se desplegaban en creación, reflexión y responsabilidad ${ }^{2}$. La obra ha sido objeto de numerosos artículos y ensayos especializados, pero también llenó muchas páginas de diarios de todo el mundo provocando intensas discusiones a nivel popular sobre las patentes de nuevos animales creados en laboratorio y sobre los límites de la ingeniería genética en la industria y el mercado. Para Kac, el uso concreto de la genética en el arte está orientado a provocar una reflexión, desde una perspectiva social y ética, incidiendo en cuestiones relevantes tales como la integración social y doméstica de los animales transgénicos. (Kac, 2010)

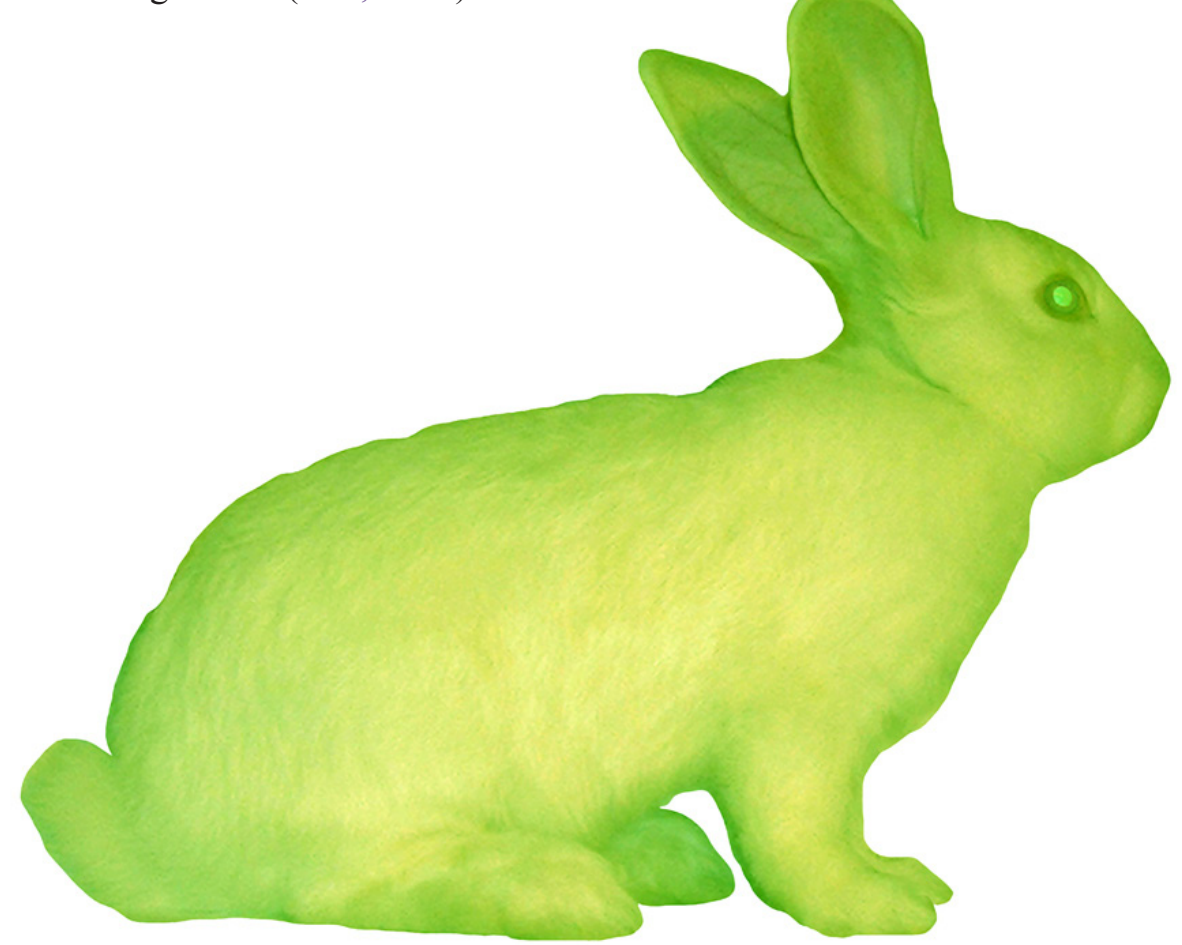

Figura 2. Eduardo Kac, GFP Bunny, 2000. Obra transgénica. Alba, la coneja fluorescente. Cortesía del artista. (C) 


\section{Baigorri-Sentido y Responsabilidad: una perspectiva bioética}

Según Andy Miah (Miah, 2012), las prácticas artísticas que promueven la transgresión de los límites biológicos son más típicas del arte transhumanista, mientras que aquellas obras centradas en el escrutinio de las relaciones biopolíticas son más propias del arte posthumanista. En este sentido, la diferencia crucial entre arte transhumano o posthumano es que el primero se centra en la provocación de debate sobre el mérito de interrumpir la continuidad biológica mediante la ciencia y la tecnología, mientras que el segundo estaría interesado en expresar las consecuencias sociopolíticas de tales cambios. Pues bien, en la base de todos los trabajos de Kac, y en la de la mayoría de los aquí analizados, encontramos las mismas dosis de transhumanismo y posthumanismo enlazadas de forma indisociable, porque cualquiera de las transgresiones biológicas que plantean está orientada a implicar socialmente al público en la reflexión sobre las consecuencias del progreso científico.

En la muestra Project Genesis -inaugurada en agosto de 2013 en el centro Ars Electronica de Linz-, se expone una aséptica obra de la diseñadora alemana Johanna Schmeer que deja a nuestra imaginación las imágenes de los ratones que sugieren sus diseños. Mousetraps No. 3, 14 y 18 (2013) son tres trampas "hechas a medida" para ratones genéticamente modificados en pruebas de laboratorio: la primera, con forma de tubo en espiral, está pensada para el "ratón vals", cuyo trastorno de equilibrio sólo le permite moverse en círculos; la segunda, es un gran imán que atraería con su potente campo magnético el implante cerebral metálico del "ratón ciborg"; la tercera trampa es un altavoz que emite el canto de los pájaros con la finalidad de atrapar al "ratón cantor", desarrollado por investigadores japoneses precisamente para cantar como los pájaros. Los tres ratones descritos no son producto de la desbordante fantasía de Schmeer, sino que han sido creados expresamente en laboratorios. La artista, que argumenta su existencia real con artículos científicos muy concretos ${ }^{3}$, presenta sus diseños bajo una pregunta: ¿Qué sucede si modificamos a las criaturas vivientes y luego las ponemos en libertad? Nuestro cuestionamiento continuaría en la misma línea ¿Es necesario crear a estos seres?, ¿hay alguna utilidad que justifique su sufrimiento y existencia? La modificación genética de Kac en GFP Bunny no producía daños al animal y asumía la responsabilidad y el cariño hacia el nuevo ser creado, pero ¿qué responsabilidad hay en este tipo de creaciones de laboratorio? En la base de este debate se halla una de las obras más recientes de los artistas Revital Cohen y Tuur Van Balen. Kingyo Kingdom (2013) no es un experimento genético, sino un documental que muestra las etapas por las que pasan los peces de colores japoneses de la raza Ranchu para convertirse en preciados objetos; nos encontramos otra vez ante 

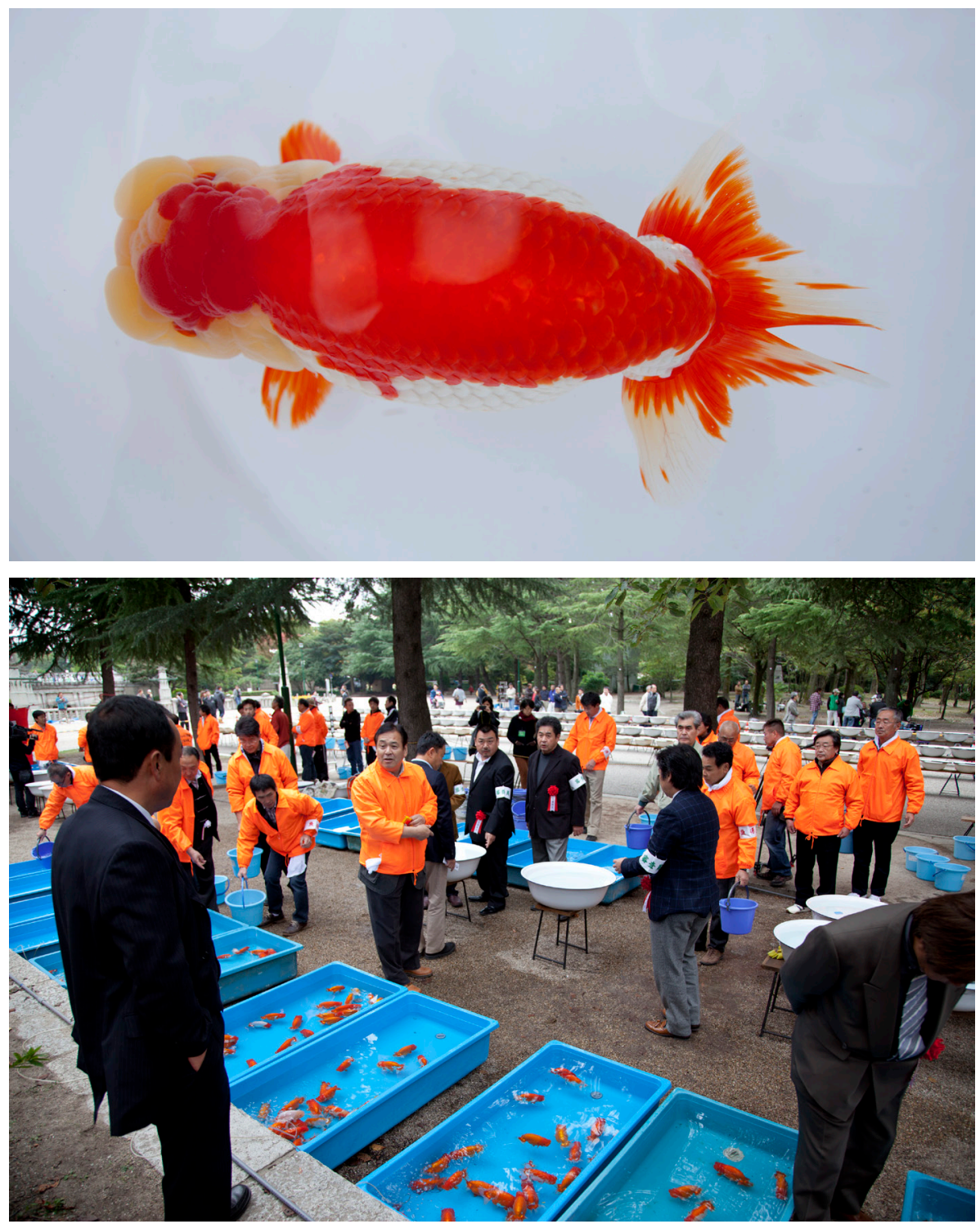

Figura 3,4. Revital Cohen y Tuur Van Balen. Kingyo Kingdom (2013). Cortesía de los artistas. (C) 


\section{Baigorri-Sentido y Responsabilidad: una perspectiva bioética}

la enésima demostración del control sobre la naturaleza ejercida por el ser humano. La manipulación del Ranchu, "The King of Goldfish", se inició en el período Edo japonés (1603-1868) en base a dos criterios básicos: un diseño específico para verse siempre desde la parte superior (visión cenital) y que su cabeza sea similar al león mitológico Shishi. Aunque esta exótica raza tiene su origen en la carpa, el objetivo de los criadores es que se parezca lo menos posible ella.

Su vídeo muestra la explicación de los criterios de los criadores, su cultivo en granjas, las fases de su comercio (mercados, subastas y embalajes), los concursos y ceremonias y, en definitiva, el tipo de economía y cultura japonesa que giran en torno a este objeto decorativo vivo. En su web los artistas afirman:

La industria de peces de colores y la cultura japonesa ilustra la existencia única de esta especie; creada por el hombre, biológicamente controlada y diseñada para fines estéticos. A diferencia de muchas otras razas manipuladas, un pez de colores no tiene "función", no se crean como alimentos, mano de obra, tutores o compañeros, sino únicamente como un ser estético.

Su investigación se centra en el diseño de los animales y, más concretamente, en las razones por las que algunos animales se consideran un objeto o un "producto vivo" antes que una mascota. “¿Qué es un bio-producto? -pregunta Cohen- La gente habla de bio-productos como si fueran el futuro, pero ya están por todas partes. Los animales que nos rodean han sido diseñados. Y Ranchu es sólo un caso muy extremo". La perspectiva aparentemente utilitarista de este discurso es el señuelo perfecto de Cohen y Van Balen, cuya estrategia parte del cuestionamiento estético para plantear una posición ética.

\section{Atención, animales trabajando}

Las reflexiones sobre la utilización de los animales han estimulado a algunos artistas a investigar si será posible el desarrollo de trabajo cooperativo entre los seres humanos y otros animales en un entorno tecnocientífico. ¿Pueden los artistas trabajar con los animales como iguales? Este fue el lema de la exposición Insterspecies - artists collaborate with animals (2009), donde el curador Rob la Frenais reunió a un grupo de artistas que cuestionan con sus obras la soberanía de la especie humana sobre las demás especies 
animales. Partiendo de esta pregunta vamos a revisar dos interesantes trabajos colaborativos entre animales y humanos que, aunque no pertenecen a esta muestra, consideramos que comparten plenamente su espíritu.

El primero es Pigeonblog (2006-2008) descrito por su autora, Beatriz da Costa, como un esfuerzo de colaboración entre palomas mensajeras, artistas, ingenieros y criadores de palomas que participaron en la recopilación y distribución de información en una base de datos sobre las condiciones de calidad del aire. Las palomas iban equipadas con un dispositivo en miniatura que medía la contaminación del aire y enviaba la información a un servidor en línea. El proyecto, que se implementó en Los Ángeles por ser una de las zona más contaminadas de EEUU, permitía que los datos enviados por las palomas se representaran muy rápidamente en un mapa desde Google Maps, de manera que cualquier persona conectada podía verlos casi en tiempo real. El propósito de Beatriz da Costa era concienciar sobre la contaminación medioambiental y, a su vez, investigar las posibilidades de coproducción entre especies trabajando en una misma acción de resistencia: “¿Cómo pueden ayudarnos los animales en la sensibilización a la injusticia social? ¿Podría ayudarnos su habilidad para la realización de tareas y actividades que los humanos simplemente no podemos hacer, mientras mantenemos una relación respetuosa con los animales?" (Da Costa, 2008). De esta manera, la artista conseguía unir dos de sus principales intereses vitales en un mismo proyecto: su preocupación por los animales y el entorno medioambiental, y la lucha activista. En Pigeonblog, además, aparecía ese recurrente usufructo de rebote donde una tecnología militar se aprovecha a posteriori por la industria y el comercio,... o por los activistas (una máxima hacker dice que cuando se abre una puerta siempre se puede traspasar en los dos sentidos). Porque la acción de da Costa se había inspirado en una tecnología, desarrollada por Julius Neubronner en 1908, que de inmediato se utilizó para la vigilancia aérea militar en la Primera Guerra Mundial. El invento del ingeniero alemán consistió en colocar alrededor del cuello de las palomas una pequeña cámara con un temporizador mecánico que tomaba fotografías periódicamente mientras éstas sobrevolaban las zonas de interés. La nueva versión de la artista equipaba a las palomas de una forma muy similar y para la misma actividad, las tomas aéreas, pero, por supuesto, con una finalidad completamente distinta.

Revital Cohen y Tuur Van Balen también trabajaron con palomas en su proyecto Pigeon d'Or (2011), pero ahora mismo nos interesa Life Support (2008), una tarea de cooperación entre especies inspirada en la labor de los animales de asistencia (perros-guía, y perros y gatos de asilos y 
servicios psiquiátricos). Este proyecto proponía el uso de animales criados comercialmente para el consumo o el entretenimiento, tales como ovejas y galgos, como proveedores de reemplazo de órganos externos, ofreciendo una alternativa a terapias médicas más duras con los humanos. En Respiratory Dog, la apuesta es que los pacientes dependientes de ventilación mecánica adopten un galgo retirado de las carreras para convertirlo en un perro de asistencia respiratoria. De esta simbiótica manera ambos se pueden mantener vivos el uno al otro.
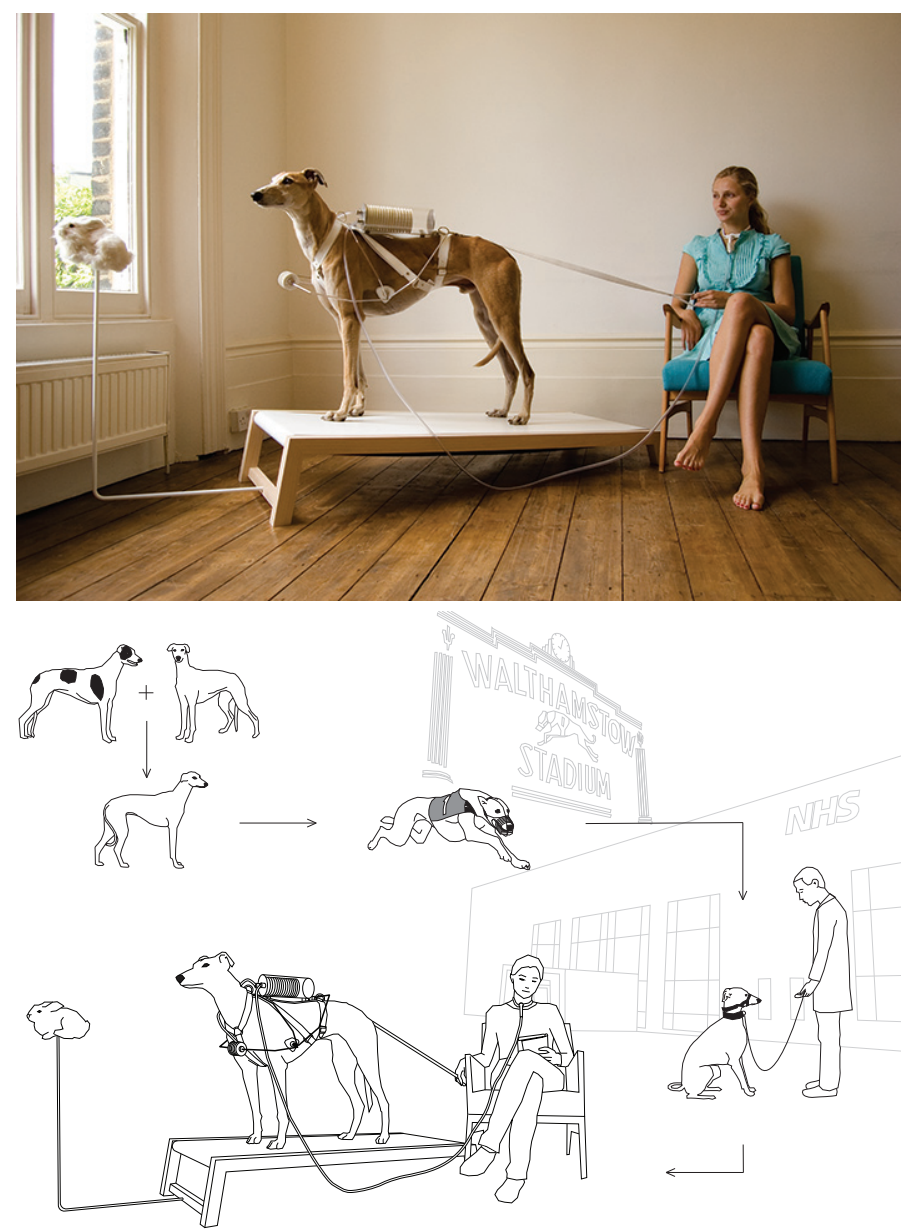

Figure 5. Revital Cohen y Tuur Van Balen. Respiratory Dog, Life Support serie (2008). Cortesía de los artistas. (C) 
Lo mismo sucede con Dialysis Sheep, que contempla la sustitución de una máquina de diálisis por una oveja. Tras posibilitar el nacimiento de un cordero transgénico compatible con el ADN del humano, éste se utilizaría para la diálisis del paciente: durante el día, la oveja se alimentaría normalmente y pasearía por un jardín, y por la noche se conectaría al paciente para filtrar la sangre de sus riñones mientras ambos duermen. En estas relaciones simbióticas, animales, humanos y máquinas coexisten gracias a una estructura compleja que permite la mutua dependencia entre distintas especies. A priori, este controvertido proyecto resulta básicamente utilitarista, puesto que su pretensión más inmediata es transformar a los animales en productos sanitarios. Pero si avanzamos un poco más, constataremos que Cohen y Van Balen inciden de forma especial en la dependencia humana de la animal, demostrando que la necesidad es mutua; de hecho, en la base de su trabajo se encuentra siempre la subversión de los roles de poder entre el hombre y su entorno. "¿Podría funcionar un animal transgénico como un mecanismo conjunto y no simplemente como suministrador de piezas? ¿Podrían los humanos convertirse en parásitos y vivir de las funciones del cuerpo de otro organismo?". En último término, los artistas están cuestionando la instrumentalización de los animales por parte del hombre, porque hace mucho tiempo que los animales son productos sanitarios. $Y$ es que una parte de la investigación científico-médica de los últimos años se centra de forma específica en investigar la compatibilidad de órganos animales -generalmente de cerdos- con los humanos; la técnica biomédica que permite trasplantar corazones, pulmones, riñones, hígados y tejidos de un animal donante clonado a un humano receptor se denomina xenotrasplante.

Retomaremos este tema al final, pero plantearemos ya una cuestión fundamental: partiendo del buen trato hacia al animal, que se cumple en estos últimos proyectos (Pigeon Photogaphy, Pigeonblog y Life Support) ila finalidad de la acción -ganar la guerra, preservar el medioambiente, mejorar la calidad de vida de los enfermos- es determinante en la utilización que los humanos hacemos de los animales?

\section{Máxima empatía e hibridación: colocarse en el lugar del otro (animal)}

¿Qué es lo que puede impulsar a alguien a convivir y dormir junto a un cerdo vivo? ¿Y a bailar con un cerdo muerto? Una máxima empatía, ciertamente. El convencimiento de que ese ser no es alguien muy distinto a uno mismo. Estas 


\section{Baigorri-Sentido y Responsabilidad: una perspectiva bioética}

dos performances las ha realizado de forma literal Kira O'Reilly, una artista irlandesa especialmente preocupada por la ética de la interacción humano/ animal y por la violencia implícita en la utilización de los animales como recurso. O'Reilly habla siempre de "animales humanos" y "animales no humanos" -lo cual ya es una declaración de principios- y para argumentar su postura cita a la artista eslovena Polona Tratnik en su texto Flesh of the World.

Maurice Merleau-Ponty ha creado el concepto de la carne del mundo. Las cosas se pertenecen recíprocamente una a otra y, por lo tanto, forman parte de la misma carne, la carne del mundo. (...) El mundo no existe frente a mí, sino que es todo lo que me rodea, vivo en él y formo parte de él. Lo vivo desde dentro, estoy inmerso. Soy una parte de la carne del mundo donde todo está entrelazado. El mundo está hecho de la misma sustancia, como un cuerpo. (Tratnik, 2006)

Tras una residencia en el laboratorio de SymbioticA, O'Reilly se dio cuenta de las similitudes entre la piel del cerdo y la de los humanos e ideó Inthewrongplaceness (2005), una performance donde bailaba con un cerdo muerto, a la vez que invitaba al público a tocar alternativamente su propia piel y la del cerdo. Porque no sólo los órganos internos de los cerdos son similares a los humanos, sino que el parecido entre nuestras pieles es tal que, en los primeros experimentos con bombas atómicas realizados en los años 50 en el desierto de Nevada (EEUU), los militares norteamericanos colocaban a cerdos (vestidos de uniforme) en los espacios próximos a las explosiones con el objetivo de comprobar cuáles serían los efectos de las radiaciones en la piel humana ${ }^{4}$. En la otra performance, Falling asleep with a pig (2009), la artista exploró los límites de su convivencia con la cerda Deliah al compartir durante unos días una pocilga especialmente construida para ellas en la sala de exposiciones. Allí comieron y durmieron juntas ante un público impresionado por la naturalidad y la ternura de la relación que contemplaban.

En esta misma línea empática de trabajo encontramos las esculturas hiperrealistas de la artista australiana Patricia Piccinini, unas criaturas inquietantes aunque extrañamente familiares, cuya sensación de vulnerabilidad provoca nuestra curiosidad e instinto de protección. En The Long Awaited (2008), una especie de sirénido anciano, mitad humano mitad animal, reposa plácidamente en los brazos de un niño, ambos con los ojos cerrados, serenos y confiados; en Litter (2010) tres bebés de espalda peluda se acurrucan entre ellos dormitando, y en The Listener (2012) un pequeño ser con cuerpo de... 
¿cerdito? y rostro humanoide reposa sobre un enorme altavoz mientras sonríe tímidamente buscando nuestra aceptación. Realizadas con silicona, fibra de vidrio, cabello humano, pelo de animal y ropa -y, en alguna ocasión, con mecanismos y altavoces ocultos en su interior-, las esculturas de Piccinini nos interrogan sobre nuestra responsabilidad para con las criaturas que creamos o las que compartimos la vida. Sabemos que estas son completamente artificiales, pero su apariencia de desprotección y la extraña mezcla de humanidad y animalidad de sus expresiones nos impulsa a preguntarnos ¿qué es lo que sienten estos seres?,... Resulta inevitable mencionar la escena final de La semilla del diablo/Rosemary's Baby (Polanski, 1968), cuando Mia Farrow acuna en sus brazos al anticristo que acaba de dar a luz.

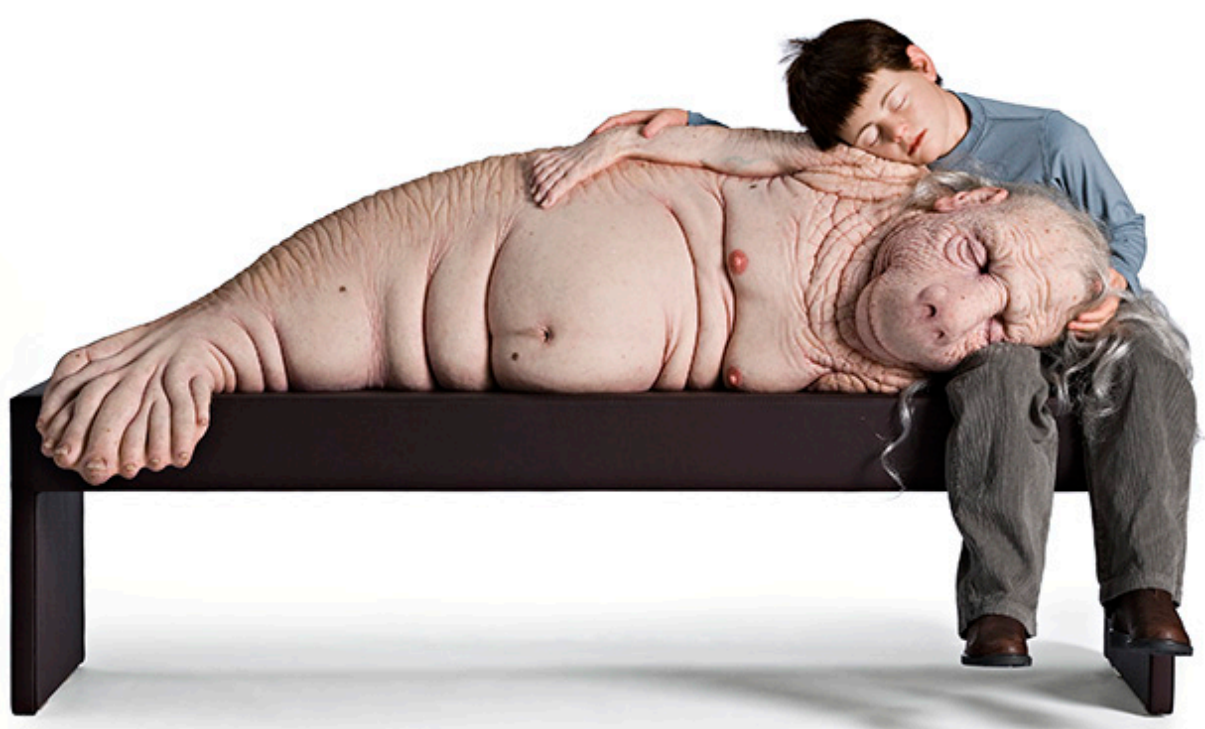

Figure 6. Patricia Piccinini. The Long Awaited, 2008. Silicona, fibra de vidrio, cabello humano, contrachapado, cuero, ropa, 152x80x92cm. Tolarno y Roslyn Oxley9 Galleries. Foto: Graham Baring. (C) 


\section{Baigorri-Sentido y Responsabilidad: una perspectiva bioética}

\section{Viaje de ida y vuelta: Plantúmanos y humanimals}

En el campo de la experimentación biotecnológica, la unión con otro ser alcanza su punto álgido en la hibridación, en la mezcla del ADN de dos seres vivos que da como resultado un nuevo ser que contiene a los dos; estamos ante la generación creativa de vida mediante técnicas de laboratorio. $\mathrm{Y}$ en el territorio del bioarte, estos procesos ya han tenido lugar entre plantas y humanos, e humanos y animales.

En 2009, Eduardo Kac ganó un Premio Golden Nica de Ars Electrónica con su proyecto Historia Natural del Enigma (2009), la creación del plantimal -o plantúmano- "Edunia", que es un híbrido genético entre Eduardo y una petunia. El ADN extraído de la sangre del artista se mezcló con el de la planta para manifestarse en las "venas" también rojas de la flor, compartiendo ambos esta consanguineidad. Además de las consiguientes implicaciones éticas, el proyecto contempla dos ideas singulares: Una es que, como el ADN humano se integra en el cromosoma de la Edunia, cada vez que ésta se propague a través de sus semillas el gen humano estará presente en las nuevas flores propagando de forma natural los genes del artista en las plantas. Y la otra que, haciendo gala de su estilo característico, Kac propone una nueva paradoja para mezclarse con la planta, escogiendo en concreto el gen responsable de la identificación de cuerpos extraños. "Esta secuencia genética que es parte de mi sistema inmune me distingue a mí mismo del no-yo, es decir, me protege contra moléculas extrañas, enfermedades, invasores - todo lo que no soy yo". Esto es, precisamente, lo que le interesa de la propuesta conceptual, que el elemento que condensa su propia defensa y rechazo del otro sea, a su vez, lo que le funde con el otro.

Los filósofos Pitágoras (580-500 a.C.) y Empédocles (495-435 a.C.) creían que animales y humanos poseen el mismo tipo de alma inmortal, de manera que las dos especies podíamos reencarnarnos alternativamente en uno y otro. Y Teofrasto (371-286 a.C.) todavía iba más allá asegurando que los animales son iguales a los humanos, no sólo respecto a su percepción de los sentidos y emociones, sino porque pueden participar en el proceso de razonamiento. Más allá de estas creencias, la afinidad entre humanos y animales alcanza su cota más alta cuando ambos consiguen compartir el mismo cuerpo. Y si en el caso anterior, la especie "invasora" ha sido la humana (una parte de ADN humano inoculado en el organismo de una planta), vamos a ver ahora el proceso de experimentación inverso: cuando parte del ADN de un caballo entra en el cuerpo de un humano. Nos encontramos entonces ante un humanimal. 
Eduardo Kac

The Making of Natural History of The Enigma

Edunia, transgenic flower expressing artist's own DNA in petal veins
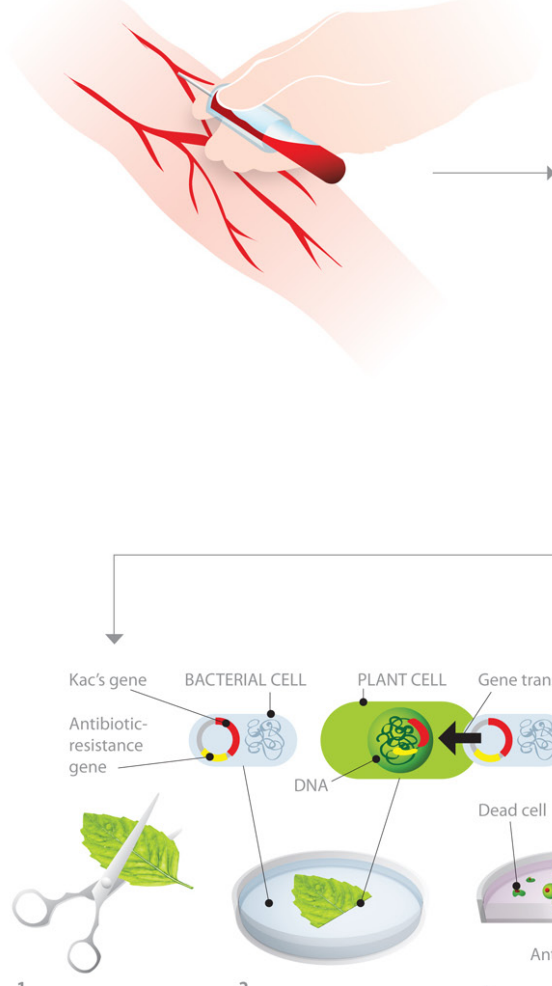

Cut Leaf
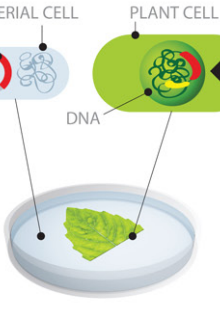

2

Expose leaf to bacteria

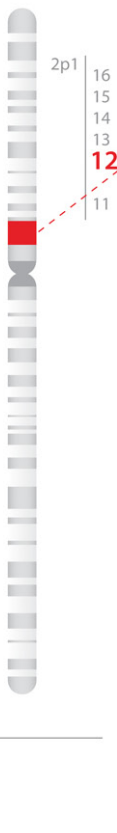

PLANT CELL Gene transfer carrying the new gene and an antibioticresistance gene. Allow bacteria to deliver the genes into leaf cells

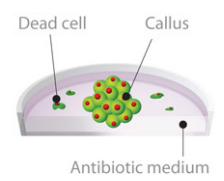

3

Expose leaf to antibiotic to kill cells that lack Kac's genes. Wait for surviving [gene-altered] cells to multiply and form a clump [callus]

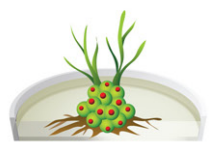

4

Allow callus to sprout shoots and roots
Kac's Chromosome 2

cgaactgtggctgcaccatctgtcttcatct tcccgccatctgatgagcagttgaaatctg gaactgcctctgttgtgtgcctgctgaata acttctatcccagagaggccaaagtacag tggaaggtggataacgccctccaatcgg gtaactcccaggagagtgtcacagagca ggacagcaaggacagcacctacagcctc agcagcaccctgacgctgagcaaagcag actacgagaaacacaaagtctacgcctgc gaagtcacccatcagggcctgagctcg Kac's gene

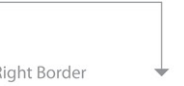

Plant Kanamycin

(1)
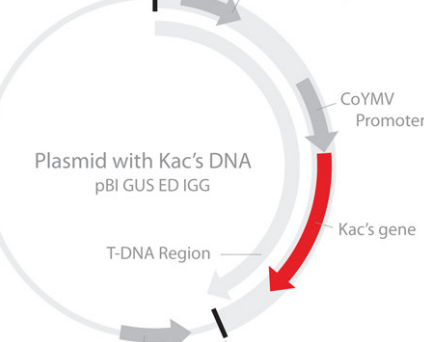

Bacterial Kanamycin

Left Border

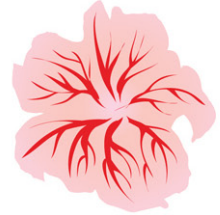

5

Put in soil. Within three months, the plantlets grow into plantimal bearing Kac's gene. The gene is expressed only in the red veins.

Figure 7. Eduardo Kac, Natural History of the Enigma, Obra transgénica, 2003/08. Edunia, un plantimal con el ADN del artista manifestado sólo en las venas rojas de la flor. Diagrama de producción. Cortesía del artista. (C) 


\section{Baigorri-Sentido y Responsabilidad: una perspectiva bioética}

En febrero 2011, Marion Laval-Jeantet y Benoît Mangin, componentes del dúo francés AOO/Art Orienté Objet, culminaron un largo y arriesgado proceso de experimentación en la performance May the horse live in me (2011), que podría describirse como un ritual de hermandad humano-animal donde los artistas asumieron el riesgo de la hibridación orgánica con otra especie. Durante la performance, en la que intervino un hermoso caballo, Benoît Mangin inyectó la sangre del animal a Marion Laval-Jeantet y después ella se colocó unas prótesis, a modo de extremidades equinas, para acercarse al caballo a la altura de sus ojos y completar el rito de comunión. La acción finalizó con la toma de una muestra de la sangre mixta de Marion -"la sangre de un centauro"- que se coaguló a los diez minutos de haberse extraído debido a la infección. El proceso requirió meses de experimentación clínica previa para que ella pudiera desarrollar tolerancia a los anticuerpos de sangre ajena porque, además del choque anafiláctico, la trasfusión de sangre de caballo a un humano comporta muchos más riesgos. Por eso excluyeron algunas células en el proceso (citotóxicos, linfocitos y macrófagos), aunque sí incorporaron la inmunoglobulina, que transfiere información a todos los órganos del cuerpo. Durante la acción en la sala, Marion padeció fiebre y debilidad, pero dos días después se produjeron una serie de reacciones atípicas en su cuerpo: intermitencias rápidas del sueño (era incapaz de dormir más de una hora cada vez), excesivo apetito, una gran sensación de fuerza... y pánico irracional cuando alguien le golpeó el brazo accidentalmente: una serie de síntomas más propios de un equino que de un humano. Durante varios años, Art Orienté Objet se han interesado por la psicología animal, la biología y la etología, pero nunca habían asumido un riesgo tan radical para expresar su protesta contra la dominación humana. Los artistas afirman que este proyecto, que les valió un Premio Golden Nica en la edición de Ars Electronica de 2011, es la consecuencia de un estado de frustración por su incapacidad para colocarse en el lugar de un animal porque, a pesar de sus mejores intenciones éticas, la visión antropocéntrica resulta siempre ineludible. Marion Laval-Jeantet afirma al respecto:

He hecho muchos trabajos sobre los animales -obras de naturaleza simbólica, política y poética-, pero llegó un momento en el que simplemente tenía que experimentar algo distinto de la percepción humana como constante referente. Era necesario para mí demostrar que los conceptos establecidos sobre las barreras entre las especies nos están limitando, e inevitablemente se requiere la investigación científica para 
superarlos. (...) Con el tiempo me di cuenta de que sólo un experimento en mí misma me ayudaría a transformar mi forma de aprender y percibir las cosas, y que con esta nueva sensibilidad sería capaz de crear una nuevo tipo de obras. (Hirszfeld, 2011)

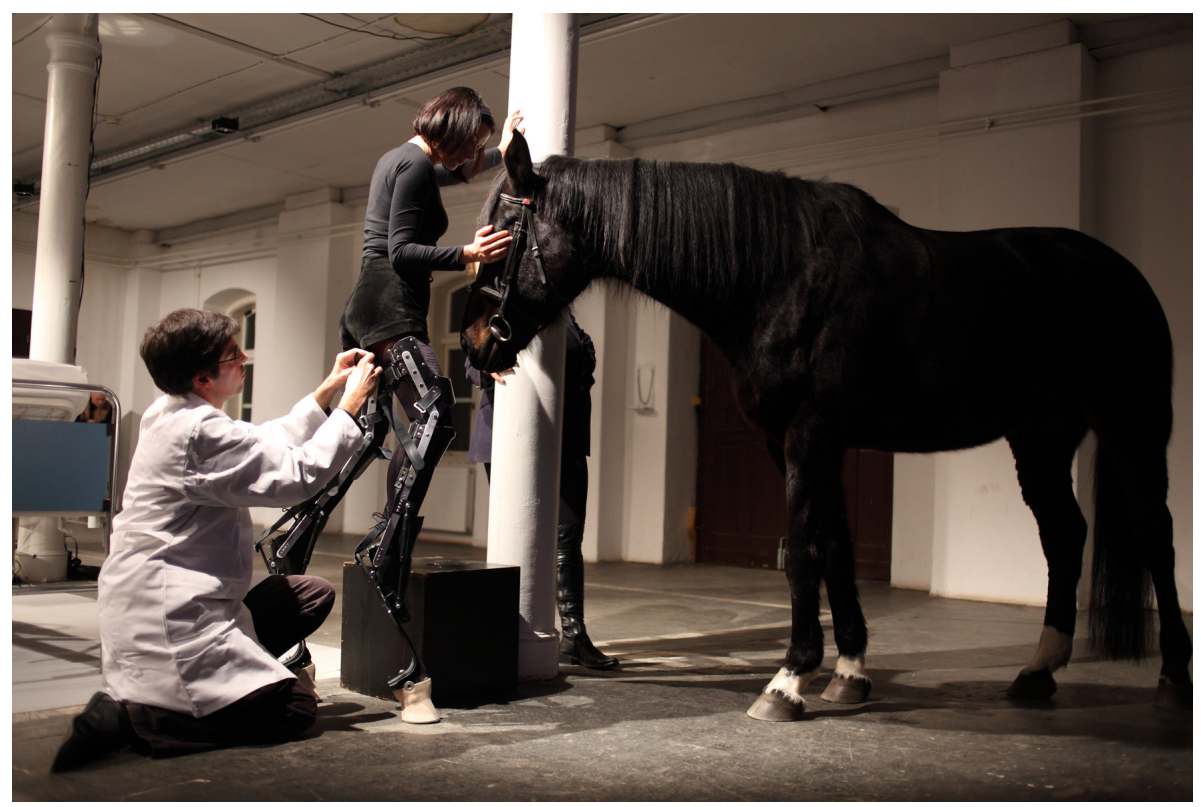

Figure 8. AOO (Art Orienté Objet), May the horse live in me, 2011. Cortesía de los artistas. (C)

Estos proyectos alcanzan su objetivo de empatía extrema porque los artistas se colocan en el lugar del otro a partir de la introducción literal de una parte del otro en su propio cuerpo (o viceversa). Se produce entonces un estallido de los límites entre las especies y comienza el verdadero intento de disolución de control sobre las demás criaturas. Pero más allá de manifiestos y demostraciones explícitas, Donna Haraway nos recuerda que esta fusión de especies se viene produciendo de forma natural en cada ser humano desde el inicio de los tiempos:

Me encanta el hecho de que el genoma humano se encuentre en sólo el $10 \%$ de todas las células que ocupan este espacio mundano que llamo 


\section{Baigorri-Sentido y Responsabilidad: una perspectiva bioética}

mi cuerpo; el otro 90\% de estas células están llenas de genomas de bacterias, hongos, protistas y demás, algunos de los cuales crean la sinfonía necesaria para mantenerme viva y otros se vienen a dar una vuelta en mí, en nosotros, sin dañarnos. Estoy ampliamente superada en número por mis pequeños compañeros, mejor dicho, me convierto en un humano adulto en compañía de estos pequeños seres. Llegar a ser es siempre llegar a ser con muchos. (Haraway, 2008)

En último término, nuestra responsabilidad con la vida en este planeta pasa por procurar la supervivencia conjunta de todas las especies; dicho de otra forma: o somos todos,... o no seremos.

\section{Responsabilidad y asunción de consecuencias: una negociación ética}

Según Hans Jonas, con cuyas palabras iniciábamos este texto, el deber de la responsabilidad humana para con la naturaleza aumenta conforme se tornan más complejos los condicionantes que impone nuestra sociedad tecnológica. Para el filósofo, la responsabilidad deriva de la libertad; sólo los humanos pueden escoger de forma consciente entre diferentes alternativas de acción, pero esa libertad de elección comporta consecuencias (Jonas, 1979). Y si hasta ahora hemos priorizado las intenciones, vamos a centrarnos a partir de aquí en las consecuencias.

Una de las obras más inquietantes que se han podido apreciar en la exposición Project Genesis anteriormente mencionada, es Into Your Hands Are They Delivered (2013), un work in progress del británico Tobias Revell cuyo título ("en tus manos entrego") nos vuelve a conectar con el versículo bíblico del Génesis que comentábamos al principio, cuando Dios otorga a los hombres el dominio sobre los animales. En este caso, la pieza es más narrativa que experimental y consiste en un gran despliegue de datos, textos e imágenes que nos explican una turbadora y apocalíptica historia. El eje y origen del proyecto se encuentra en las Ichneumonidae, unas avispas que ponen sus huevos en los cuerpos de otros insectos, de manera que cuando nacen las larvas devoran a sus anfitriones desde el interior. A partir de aquí, Revell especula sobre una futura evolución de este versátil parásito donde una cepa de la avispa se adaptaría a un proceso de abiogénesis con productos petroquímicos y plásticos; es decir, comenzaría a poner sus huevos en petróleo y gasolina, dejando a las grandes empresas del sector completamente desbordadas por esta gran epidemia con 
alarmantes y definitivas consecuencias, tanto biológicas como financieras.

En esta distópica obra el artista interpela al público: ¿Cómo es posible que estas criaturas, cuyo principio de vida parece tan cruel, sean la creación de un Dios benevolente? ¿Pero acaso somos nosotros, los seres humanos, superiores a los animales? ¿Dónde está la frontera entre la humanidad y la naturaleza? Revell nos invita a hacer una pausa y reflexionar sobre la tipología especulativa del Ichneumonidae y su gran similitud con la actitud de los humanos en nuestro trato habitual al resto de especies y a la naturaleza en general; su propósito es que tomemos conciencia de lo que puede comportar la violación de los límites entre el hombre y la naturaleza.

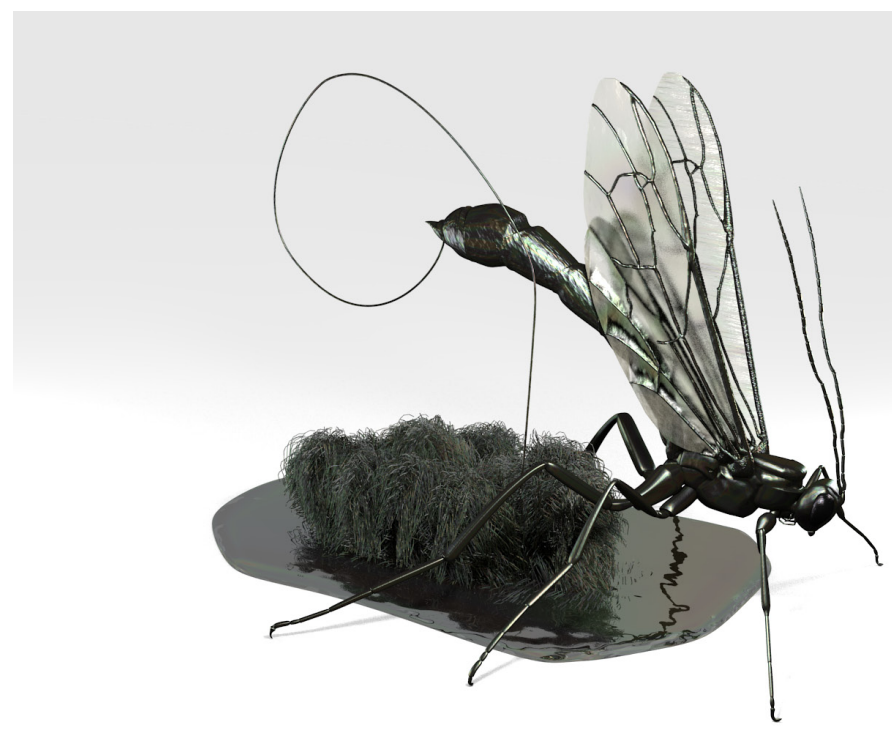

Figure 9. Tobías Revell, Megarhyssa Petrolis hyper-parasitising Larvae, 2013. Cortesía del artista. ()

En este sentido, Revell sigue la estela de Jonas, cuyo imperativo ético parte del miedo o, en sus palabras, de una heurística del temor (Heuristik der Furcht), que significa respeto mezclado con miedo. "Jonas sostiene que es el miedo a las consecuencias irreversibles del progreso, como la manipulación genética y la destrucción del habitat, lo que obliga a actuar imperativamente. Por ello, el motor que impulse a obrar ha de ser la amenaza que pende sobre 
la vida futura". Revell, al igual que Jonas, considera que ante un ultimátum tan definitivo como la amenaza de la existencia (o, en último término, la desaparición de la especie), el hombre debería reaccionar también de manera absoluta:

Ante la amenaza que se cierne sobre la naturaleza, el hombre tiene el deber moral de protegerla, ese deber aumenta en la medida que sabe lo fácil que es destruir la vida; por ello, en la actualidad la ética debe tener en cuenta las condiciones globales de la vida humana y de la misma supervivencia de la especie. La idea fundamental sobre la que se sustenta este planteamiento (de Jonas) es la experiencia de la vulnerabilidad; las generaciones actuales tienen la obligación moral de hacer posible la continuidad de la vida y la supervivencia de las generaciones futuras. (Cardozo, 2003)

Posiblemente, la mayor instrumentalización de los animales por parte de los humanos se lleva a cabo en los laboratorios farmacológicos y médicos de todo el mundo -recordemos de nuevo Mousetraps No. 3, 14 y 18 (2013) de Johanna Schmeer-. Allí es donde se les inocula enfermedades y virus, y donde se experimentan cirugías y medicaciones para comprobar sus efectos. Porque para los humanos, al igual que para las avispas Ichneumonidae, el sacrificio de otras especies comporta la supervivencia de la nuestra. Rabbits Were Used to Prove (1999) de Art Orienté Object muestra el cuerpo disecado de un conejo blanco cuyas entrañas han sido reemplazadas con otras realizadas con lana obtenida de la oveja Dolly, el primer mamífero clonado a partir de una célula somática adulta. Aunque a primera vista pueda parecerlo, la obra no está planteada como una simple crítica a la ciencia o a la utilización de animales de laboratorio, sino que confronta al espectador a la misma encrucijada a la que se enfrentan sus creadores:

La ciencia salva la vida, pero también la sacrifica. Es muy sintomático de nuestra forma de vida en la Tierra -nuestra supervivencia es a costa de los demás-. Este trabajo es más existencial que crítico. En este sentido, me siento cerca de lo que Vladimir Makanin ha escrito. Para nosotros la ciencia no es una posición ideológica, sino un instrumento del que no podemos prescindir si queremos comprender el mundo. Este instrumento, sin embargo, tiene muchas contradicciones internas que pueden ser muy peligrosas para un individuo. Cada vez que utilizamos esta herramienta iniciamos un juego con unos límites de sensibilidad flexibles. (Hirszfeld, 2011) 
Finalizaremos esta reflexión con una obra que alude a la experimentación con las ratas, el animal de laboratorio por excelencia, y donde Beatriz da Costa expone, de forma audaz y en primera persona, las contradicciones humanas. Dying for the Other (2011) es un tríptico de vídeo que yuxtapone las vidas de los ratones utilizados en la investigación del cáncer de mama y la de un ser humano que padece la misma enfermedad, en este caso, la propia autora. Beatriz da Costa documentó el proceso de su enfermedad cancerígena durante los tres meses del verano de 2011 a la vez que grababa, en un laboratorio de Nueva York, a un grupo de ratones a los que se les había inoculado el cáncer:

En este proyecto no intento subrayar ninguna diferencia entre la vida humana y la de un ratón, sino más bien la interconexión que hay entre ambas vidas -aseguraba la artista en una entrevista-. Los ratones son "un animal modelo" usado para desarrollar soluciones para el tratamiento de cáncer de mama. En consecuencia, muchos de ellos tienen que sufrir y morir en un intento de mantener a las personas vivas. En el vídeo exploro el sufrimiento de los dos: ratones y seres humanos. (Lieja Quintana, 2011)

La obra forma parte de un proyecto más amplio titulado The Cost of Life que cuestiona cómo producimos y sostenemos una vida desde diferentes perspectivas -la ética, la emocional y la económica-, evidenciando la complejidad de una práctica que va más allá de mantener un tipo de vida a costa de matar a otro. Beatriz da Costa trabaja en la misma línea que la artista Patricia Piccinini, cuando afirma:

No creo que realmente se pueda -o se deba- tratar de entender la ética sobre algo sin las emociones. Se puede argumentar fácilmente que un enfoque en la empatía podría distraernos de la verdadera comprensión racional de los problemas, pero, de hecho, eso es exactamente lo que yo pretendo. El carácter empático de mi trabajo complica deliberadamente las ideas. Una cosa es argumentar a favor o en contra de la clonación cuando sólo es una cuestión intelectual. Sin embargo, las cosas cambian si tenemos una madre o un hijo que pueda necesitarlo. La ética no se establece de la misma forma que la moral, sino que se debe negociar constantemente. (Piccinini, 2007) 


\section{Baigorri-Sentido y Responsabilidad: una perspectiva bioética}

Así pues, parece que los principales interrogantes de este texto planean en torno a la vieja cuestión maquiavélica sobre si el fin justifica los medios. Y aunque partimos de un claro posicionamiento, nuestras preguntas no esperan una respuesta categórica o concluyente porque ésta no existe. No es a la moral, a quien se dirigen, sino a la ética; y la postura ética personal no se puede fijar para todas las cosas, sino que se adecua a cada situación en particular, es decir, se negocia según las circunstancias específicas de cada realidad concreta. Beatriz da Costa sobrellevó su "realidad concreta" ejemplificando hasta las últimas consecuencias el lema arte $=$ vida. The Cost of Life fue el último proyecto de una persona inteligente y valiente que murió de cáncer el 27 de diciembre de 2012 en Nueva York. Con su vida y su trayectoria artística e intelectual, Beatriz da Costa (1974-2012) ha ayudado a cambiar las ideas y expectativas de otras personas, más allá de su muerte.

\section{Epílogo}

El largo camino de convergencia investigadora entre artistas y científicos se iniciaba en 1959, cuando Lord Charles Pierce Snow (Snow, 1963) declaró la disociación categórica entre ciencias y humanidades en su célebre conferencia The Two Cultures and the Scientific Revolution (Cambridge, 1959). Esta disertación estaba orientada a reflexionar sobre las condiciones de un mundo más justo y sostenible antes que a abordar específicamente la dualidad del arte y ciencia, por lo que posteriormente reconsideró su postura sobre esta división radical y, en 1963, publicó un nuevo ensayo titulado The Two Cultures: A Second Look donde se planteaba el potencial de una Tercera Cultura abierta a la comunicación entre intelectuales literarios y científicos. En 1995, John Brockman asentó las bases de esa Tercera Cultura (Brockman, 1995), proyectando una construcción cooperativa que facilitase una comunicación intercultural más efectiva y creativa; por supuesto, esta es una propuesta todavía en trámites de consolidación. Siguiendo la estela de sus predecesores, Roger Frank Malina dio una conferencia titulada LeonardoTimeshift. 1959, 1969, 2004, 2029 (Ars Electronica 2004), donde argumentaba dos posibles opciones de fusión entre arte, ciencia y tecnología en nuestro futuro inmediato: La opción débil y la opción fuerte. La primera se fundamenta en la interacción entre artistas, científicos e ingenieros para contribuir con resultados mejores y más rápidos a la resolución de problemas científicos o de ingeniería. La opción fuerte, sin embargo, sostiene que en 
unos 20 años surgirán nuevas iniciativas y metodologías de interacción entre artistas, científicos e ingenieros a partir de una ciencia o ingeniería "diferente" porque se habrá producido un cambio sustancial en los contextos sociales e institucionales que hasta ahora definen cuáles son los problemas, qué soluciones son exitosas y en qué áreas se debe priorizar la financiación. A partir de aquí, Malina se atreve a augurar una "Quinta Cultura" que debería implantarse dentro de unos 50 años. En lugar de articular las opciones en oposiciones binarias, considera que será más productivo recuperar la metáfora de la red y ver el arte, la ciencia, la tecnología como una red continúa de "caminos" para comprender y actuar sobre el mundo ${ }^{5}$ (Malina, 2004).

En julio de 2006, el investigador y artista Stephen Wilson escribía en el statement de su web:

Estoy asombrado y preocupado al mismo tiempo por el curso de la investigación científica y tecnológica. Históricamente, las artes vigilaban la frontera cultural, alertaban a la gente sobre los nuevos acontecimientos, examinaban las implicaciones tácitas y exploraban los futuros alternativos. Me temo que en el mundo dominado por la tecnología contemporánea está fallando esa responsabilidad.

Años antes, ya había argumentado las razones por la cuales consideraba fundamental la labor de los artistas en la confluencia del arte, la ciencia y la tecnología: porque partiendo de los mismos datos los artistas pueden introducir nuevas preguntas y asignar diferentes prioridades a una investigación, porque pueden cuestionar los procedimientos de investigación estándar o inventar otros nuevos, porque pueden inventar nuevas tecnologías y nuevas maneras de acceder al conocimiento, porque pueden interpretar los resultados de manera diferente y porque pueden identificar implicaciones culturales de los resultados de investigación que otro tipo de investigadores no tienen en cuenta (Wilson, 2002; Wilson, 2004). La certificación de esta nueva perspectiva queda patente en algunas de las principales preguntas que los artistas analizados han formulado con sus obras:

¿Es necesario crear a determinados seres?, ¿cuál es nuestra responsabilidad hacia las creaciones de laboratorio?, ¿qué sucede si modificamos a las criaturas vivientes y luego las ponemos en libertad?

¿Qué derecho tienen los artistas a crear o mutar genéticamente a los seres vivos?, ¿el principal inconveniente es que la manipulación se 


\section{Baigorri-Sentido y Responsabilidad: una perspectiva bioética}

establezca desde el mundo del arte?, ¿pueden los artistas trabajar con los animales como iguales?

¿Podrían ayudarnos los animales en la realización de tareas que los humanos no podemos hacer, mientras mantenemos una relación respetuosa con ellos?, ¿podría funcionar un animal transgénico como un mecanismo conjunto y no simplemente como suministrador de piezas?, ¿podrían los humanos convertirse en parásitos y vivir de las funciones del cuerpo de otro organismo?

¿Cuáles son los límites de la fusión entre especies?, si fuéramos capaces de crear seres híbridos entre animales y humanos ¿qué percepción tendríamos de su alteridad, en qué rango les ubicaríamos y cual sería nuestra responsabilidad hacia ellos?

En la actualidad, ya no se puede asegurar que la investigación artística sea una actividad marginal en este campo. La justificada preocupación de Wilson está siendo superada por numerosos artistas, conscientemente involucrados en las zonas fronterizas de la ciencia y la tecnología, que asumen el papel de provocadores con el objetivo de implicar socialmente al público en las consecuencias de la innovación y el progreso científico. Históricamente, la responsabilidad de los artistas ha sido propiciar la reflexión y cuestionar los desafíos de su tiempo y si en un momento dado el interés del arte se centró en la crítica social y política, ahora mismo la necesidad de análisis crítico y debate pone también su acento en el territorio de la tecnociencia. Desde distintas perspectivas, todos los proyectos analizados en este texto ilustran los retos que plantean los artistas que trabajan en el bioarte, en su responsabilidad y obligación de abrir nuevos debates éticos sobre la ciencia.

\section{Agradecimientos}

Investigación para el proyecto I+D Metamétodo: Metodologías compartidas y procesos artísticos en la sociedad del conocimiento, 2011-2013, Universidad de Barcelona.

By downloading the images on this link you agree to the following conditions:

The use of these files is strictly limited to this single use: The BRAC Magazine. Any further reproductions, reprints or distribution to third party of these files will be considered a breach of copyright. After the authorized use of these images, the download links and their contents must be deleted. The use of the image files for additional prints - in particular for commercial purposes (catalogues, postcards, posters), without written permission is strictly prohibited. 


\section{BRAC - Barcelona Research Art Creation, 2(2)}

\section{Notas}

1 Las diferencias entre un Gran Danés -hasta $2 \mathrm{~m}$ de altura y de $60 \mathrm{~kg}$ a $100 \mathrm{~kg}$ - y un Yorkshire Terrier -entre 15 y $30 \mathrm{~cm}$ de altura y de 1 ' $5 \mathrm{~kg}$ a $3 \mathrm{~kg}$ - no han sido producto de las azarosas combinaciones de la madre naturaleza. Las consecuencias de esta experimentación son numerosos problemas de salud asociados a sus tamaños; en el Gran Danés: torsión gástrica, displasia de cadera, enfermedades del corazón, tumores y lesiones de la cola; en el Yorkshire Terrier: luxación de la rótula, enfermedades del corazón, hidrocefalia, hipoglucemia y fontanelas abiertas.

2 El último de los tres objetivos de Kac con GFP Bunny -y quizás el más importante- no se cumplió. Aunque la conejita Alba recibió el cariño de la familia de Kac, nunca pudo ser definitivamente adoptada porque las estrictas normativas de los laboratorios impiden que cualquier animal que haya sido intervenido en ellos pueda salir "al exterior". En esta ocasión, fueron las reglas y protocolos científicos los que bloquearon los intereses éticos.

3 "Ratón vals": Stein, K. F., Huber Filosa, S. (1964), "A new mutation causing circling behaviour in mice', Journal of Heredity, Volume 55, Issue 5, pp. 247-252; "Ratón ciborg": Graham-Rowe, D. (2002), 'Robo-rat controlled by brain electrodes',

http://www.newscientist.com/article/dn2237; "Ratón cantor": Agence France Press (2010), 'Singing mouse made with genetic modification'

http://news.discovery.com/animals/zoo-animals/mouse-tweets-genetic-modification-101221.htm (consultados en agosto de 2013)

4 "Se llevaron a cabo experimentos con ratones, perros y otros animales. Los animales se sometieron a las explosiones atómicas y después fueron analizados por biólogos, veterinarios y personal médico. En 1957, para la serie Plumbbob, construyeron corrales cerca de la autopista Mercury para guardar a los 1.200 cerdos que se utilizaron en diversos experimentos. Habían sido especialmente criados para ello, debido a las similitudes entre los cerdos y fisiología humana. En algunos experimentos, se equipó a los cerdos con diversos tipos de ropa, incluyendo uniformes militares. Para la prueba de 37 kilotones del test de Priscilla, realizada el 24 de junio de 1957, colocaron a más de setecientos cerdos anestesiados en estaciones a diferentes distancias de la zona cero con el objetivo de comprender mejor los efectos de las armas atómicas en los seres humanos". Palevsky, Mary (2009), “Atmospheric Nuclear Testing at the Nevada Test Site", marzo. http://www.onlinenevada.org/articles/atmospheric-nuclear-testing-nevada-test-site (consultado en agosto de 2013)

5 Desde su punto de vista, la primera cultura sería la Cultura del Arte, el Diseño y el Entretenimiento interconectadas; la segunda, la Red de la Ciencia, con una mayor dependencia gubernamental; la tercera cultura se centraría en la Tecnología, pero vinculada más estrechamente a la industria; la cuarta cultura estaría formada por un conjunto de culturas ligadas a una serie de "visiones del mundo" dependientes de la ciencia y la tecnología; y la quinta tendría que ver con equipos de colaboración que trabajarían los puntos de encuentro de visiones locales y globales (el idioma, el origen étnico, la pertenencia a una disciplina, grupo social y localidad determinan como se define el interés de los problemas, qué soluciones se consideran exitosas y qué métodos se van a utilizar para averiguar una pregunta en particular). Malina, Roger Frank. LeonardoTimeshift 1959, 1969, 2004, 2029, Ars Electronica 2004.

http://90.146.8.18/en/archives/festival_archive/festival_catalogs/festival_artikel. asp? ProjectID=12927 (consultado en agosto de 2013) 
166 Baigorri-Sentido y Responsabilidad: una perspectiva bioética

\section{Referencias}

Brockman, J., ed. (1996). La Tercera Cultura. Más allá de la revolución cientifica, Metatemas n.43, Barcelona: Tusquets. Primera edición 1995: The Third Culture: Beyond the Scientific Revolution. New York: Simon \& Schuster.

Cardozo, L. (2003). Fundamentos filosóficos para un nuevo discurso ambiental en América Latina. Tesis doctoral, Maracaibo, Venezuela:

Universidad de Zulia. Recuperado en agosto de 2013, de http://tesis.luz.edu.ve/tde busca/arquivo.php? $\operatorname{codArquivo}=2625$

Da Costa, B. (2008, 10 de marzo). Pigeonblog. Interspecies coproduction in the pursuit of resistant action, en MutaMorphosis: Challenging Arts and Sciencies. Actas de la conferencia. Recuperado en agosto de 2013, de http://mutamorphosis.wordpress.com/?s=pigeonblog

Foucault, M. (1984). Deux essais sur le sujet et le pouvoir, en Hubert Dreyfus et Paul Rabinow, Michel Foucault, un parcours philosophique, París: Gallimard.

Haraway, D. (2008). When Species Meet, Minneapolis: University of Minnesota Press.

Hirszfeld, A. (2012), May the Horse Live in me (interview with Art Orienté Objet), en Art+Science Meeting, Gdańsk, Polonia: Laznia Centre for Contemporary Art. Recuperado en agosto de 2013, de http://artandsciencemeeting.pl/?page_id=306\&lang=en

Jonas, H. (1995). El principio de responsabilidad. Ensayo de una ética para la civilización tecnológica, Barcelona: Herder. Primera edición 1979: The Imperative of Responsibility: In Search of Ethics for the Technological Age, Chicago: University of Chicago Press.

Kac, E. (1998). Transgenic Art en Leonardo Electronic Almanac Vol. 6, N. 11. En español en: Molina, A. y Landa, K. eds. (2000). Futuros emergentes: Arte, Interactividad y Nuevos Medios, (pp.59-66) Valencia: Institució Alfons el Magnànim - Diputació de Valencia. (2010). Telepresencia y Bioarte. Interconexión en red de humanos, robots y conejos. Murcia: Cendeac. Primera edición 2005: Telepresence and Bioart. Networking Humans, Rabbits and Robots. Ann Arbor: The University of Michigan Press

Lieja Quintana, D. (2011, Noviembre). "Beatriz da Costa: The Cost of Life". Entrevista en (R)registromx. Literatura, Arte, Pensamiento, n.24. 
Recuperado en agosto de 2013, de

http://registromx.net/anteriores/24/24 bun beatriz.html

Malina, R. (2004). LeonardoTimeshift 1959, 1969, 2004, 2029, conferencia

en Ars Electronica 2004. Linz. Recuperado en agosto de 2013, de http://90.146.8.18/en/archives/festival_archive/festival_catalogs/ festival artikel.asp?iProjectID $=12927$

Menezes, M. (2003). The Artificial-Natural: Manipulating butterfly wing patterns for artistic purposes, en Leonardo Vol. 36: 29-32, Cambridge: MIT Press. DOI: 10.1162/002409403321152257

Miah, A. (2012), "Bioarte: actuación transhumana y posthumana", en Teknokultura Vol. 9 Núm. 1: 85-104. Madrid. Recuperado en febrero de 2014, de http://teknokultura.net/index.php/tk/article/view/53/pdf

Piccini, P. \& Fernández Orgaz, L. (2007). The Naturally Artificial World. En el catálogo de la exposición (tiernas) criaturas, Artium, Vitoria-Gasteiz. Snow, C. P. (1987). Las dos culturas y un segundo enfoque. Madrid: Alianza Editorial. Primera edición (1963): The Two Cultures: and A Second Look. Cambridge: Cambridge University Press.

Tratnik, P. (2006). "Flesh of the World" en a minima n. 18, Barcelona.

Recuperado en agosto de 2013, de

http://www.polona-tratnik.si/Tratnik_Flesh_of_the_World_Aminima.pdf Wilson, S. (2002). Information Arts: Intersections of Art, Science, and

Technology, Cambridge: MIT Press/Leonardo.

(2004). Potential Contributions of Artists to Biology Research, en

Poissnat, L. y Daubner, E. eds. Art et Biotechnologies, Montreal:

Presses de l'Universite du Quebec. Recuperado en agosto de 2013, de http://userwww.sfsu.edu/swilson/papers/wilson.bioartschapter.html

\section{Obras}

Eduardo Kac: Genesis (1999), GFP Bunny (2000) y Natural History of the Enigma (2009) http://www.ekac.org

Ken Goldberg: The Telegarden (1995-2004)

http://queue.ieor.berkeley.edu/ goldberg/garden/Ars/

Net-Band: The Egg of Internet (1995)

http://v2.nl/archive/works/the-egg-of-the-internet

Marina Zerbarini: Síntesis simbiótica entre una máquina y un ser vivo (2011- 
168 Baigorri-Sentido y Responsabilidad: una perspectiva bioética

2013) http://www.marina-zerbarini.com.ar/simbiosis/index.html Beatriz da Costa: Pigeonblog (2006-2008) y Dying for the Other (2011) Cohen Van Balen: Life Support (2008) y Kingyo Kingdom (2013)

http://www.cohenvanbalen.com

Marta de Menezes: Nature? (1999-2000) http://martademenezes.com/

Johanna Schmeer: Mousetraps No. 3, 14 y 18 (2013)

http://www.johannaschmeer.com/MOUSETRAPS-NO-3-14-18

Kira O’Reilly: inthewrongplaceness (2005)

http://www.artsurgery.org/Tract\%20live\%20art/Kira\%200\%27Reilly/

Kira\%200\%27Reilly.html

Patricia Piccinini: The Long Awaited (2008), Litter (2010) y The Listener (2012) http://www.patriciapiccinini.net/

AOO/Art Orienté Objet: May the horse live in me (2011) y Rabbits Were Used to Prove (1999) http://aoo.free.fr/

Tobias Revell: Into Your Hands Are They Delivered (2013)

http://into-your-hands.com/

Laura Baigorri: Profesora Titular en el Departamento de Diseño e Imagen de la Universidad de Barcelona.

Contact Address: Facultad de Bellas Artes. Universidad de Barcelona. Departamento de Diseño e Imagen. c/ Pau Gargallo 4, 08028 Barcelona (España).

E-mail address: lbaigorri@ub.edu 
Instructions for authors, subscriptions and further details:

http://brac.hipatiapress.com

\section{José Luis Guerin: Descubriendo una Sintaxis Posible}

Juan Martínez Villegas ${ }^{1}$

1) Facultad de Bellas Artes. Universidad de Barcelona. España

Date of publication: June $3^{\text {rd }}, 2014$

Edition period: February 2014-June 2014

To cite this article: Villegas, J. M. (2014). José Luis Guerin: Descubriendo una sintaxis posible. Barcelona, Research, Art, Creation, 2(2), 169-200. doi: 10.4471/brac.2014.08

To link this article: http://dx.doi.org/10.4471/brac.2014.08

\section{PLEASE SCROLL DOWN FOR ARTICLE}

The terms and conditions of use, except where otherwise noted, are related to the Open Journal System and to Creative Commons Attribution License (CCBY). The indication must be expressly stated when necessary. 
BRAC - Barcelona Research Art Creation. Vol. 2 No. 2, June 2014, pp. 169-200

\section{José Luis Guerin: Discovering another Possible Syntax}

Juan Martínez Villegas

University of Barcelona

(Received: 15 January 2014; Accepted: 20 February 2014; Published: 3 June 2014)

\section{Abstract}

José Luis Guerin has called his work as sketched cinema. From this open definition, the possible language connections between the sketched image in two of his films, Unas Fotos en la Ciudad de Silvia (2007) and Guest (2010), and the fragmented narrative that he experienced in his two audiovisual installations created to date, Las mujeres que no conocemos (2007) and La Dama de Corinto (2011), are suggested. We analyze and contrast with the film maker the status of his poetic image, in relation to his diving into contemporary art, contextualizing his search for another possible syntax within the artistic practices of those authors working in the spaces of confluence between cinema and other arts.

Keywords: Guerin, poetic image, multi-projection installation, expositive cinema, fragmented narrative, hybridization, contemporary art, sketched cinema. 
BRAC - Barcelona Research Art Creation. Vol. 2 No. 2, June 2014, pp. $169-200$

\section{José Luis Guerin: Descubriendo una Sintaxis Posible}

Juan Martínez Villegas

Universidad de Barcelona

(Recibido: 15 Enero 2014; Aceptado: 20 Febrero 2014; Publicado: 3 Junio 2014)

\section{Resumen}

José Luis Guerin ha denominado su trabajo como cine esbozado. Desde esta definición abierta, se sugieren las posibles conexiones de lenguaje entre la imagen esbozada en dos de sus films; Unas Fotos en la Ciudad de Silvia (2007) y Guest (2010) y la narrativa fragmentada, que experimenta en sus dos instalaciones audiovisuales hasta la fecha; Las mujeres que no conocemos (2007) y La Dama de Corinto (2011). Analizamos y contrastamos con el director la entidad de su imagen poética, en relación con su incursión en el arte contemporáneo, contextualizando su búsqueda de otra sintaxis posible, dentro de las prácticas artísticas de aquellos autores que trabajan en los espacios de confluencia entre el cine y otras artes.

Palabras clave: Guerin, imagen poética, instalación, multi-proyección, cine expositivo, narrativa fragmentada, hibridación, arte contemporáneo, cine esbozado. 
on la aparición de José Luis Guerin en el panorama del cine español, han surgido numerosos análisis de la evolución del trabajo del director. Desde su primer largometraje Los motivos de Berta (1983), hasta sus últimas obras expuestas en salas de arte, Las mujeres que no conocemos (Pabellón de España, Bienal de Venecia 2007) y La Dama de Corinto, un esbozo cinematográfico (Museo Esteban Vicente de Segovia 2011), Guerin traza un recorrido de correspondencias en las que se intuye la vinculación de su imagen cinematográfica con el arte contemporáneo.

El director experimenta con instalaciones multipantalla, la relación entre su imagen fílmica y el punto de vista del espectador. Realiza con ello una extensión formal y conceptual de su trabajo, dando un paso más allá en la fragmentación de sus montajes, que de por sí tienden a la no linealidad, un aspecto inherente a sus películas.

La motivación del presente escrito es el acercamiento a la mirada sensible del cineasta y a su singularidad, ya que la incursión en el arte contemporáneo no la planifica, más bien responde a la llamada de los comisarios, en la actual inclinación por incorporar las hibridaciones de la imagen cinematográfica en los circuitos expositivos.

Se exponen las posibles conexiones de lenguaje entre dos de sus obras, en las que la recolección de gestos y la mirada lírico-documental inundan el contenido; Unas Fotos en la Ciudad de Silvia (2007) y Guest (2010), con sus dos instalaciones audiovisuales Las mujeres que no conocemos (2007) y La Dama de Corinto (2011). Se orientan estos vínculos en factores comunes, como son los medios, la herramienta utilizada, la narrativa no lineal y la tendencia del director en captar, reinterpretar y dotar de espacio propio a la imagen poética.

Basamos esta relación no tanto en las estrategias expositivas, como en el germen contenido en el trabajo de un autor que oscila entre los dos campos. Situamos sus instalaciones en el ámbito de las prácticas de artistas y cineastas, que trabajan con la expansión de la imagen múltiple. Se apoyan los argumentos en diversos estudios que han analizado el fenómeno desde varias perspectivas, así como en la obra de otros autores que provienen del arte o la cinematografía, planteando las posibles fricciones que se producen en estas experiencias de hibridación. 


\section{Martinez Villegas - Guerin: Descubriendo una sintaxis posible}

Para contrastar estos planteamientos, incluimos como Anexo la conversación inédita mantenida con el director, en la que hacemos una aproximación a la evolución de su singular obra. Le preguntamos el porqué de su incursión en el arte contemporáneo y su opinión acerca de la inclusión del cine en museos y salas de arte, diferentes aspectos de su pensamiento cinematográfico y artístico, los métodos con los que elabora su imagen, y la relación que guardan algunas de sus obras aparentemente dispares entre sí.

\section{La Imagen Poética y el Cine Esbozado}

El director ha denominado la orientación de su trabajo como cine esbozado, invitando al espectador a participar en ese proceso abierto. El sentido de la palabra esbozo en sus posibles acepciones, se refiere a la proyección de una intención que potencialmente podría desarrollarse: "Dibujo inacabado y esquemático de un proyecto artístico; Aquello que puede alcanzar mayor desarrollo y extensión; Tejido, órgano o aparato embrionario que todavía no ha adquirido su forma y estructura definitivas; Insinuación de un gesto". ${ }^{1}$ Cuando observamos un trazo primario en cualquier arte, éste nos remite a un momento bruto, una imagen intuida en el proceso de una obra, que más tarde se completa o no.

La denominación cine esbozado nos habla de la libertad para decidir hasta qué punto se cierra una escena, o de la invitación al espectador para completar lo que deliberadamente se le muestra indefinido. La secuencia poética de Guerin puede leerse como una imagen-gesto, que contiene una semilla, una idea abierta. Son aspectos de su obra que pertenecen al ámbito procesual, de pura creación, en el que la expresión depende de una mirada y de una cámara, que recoge algo que está fuera de él, pero de algún modo le pertenece. Momentos en los que la poesía surge.

Sus películas se interesan especialmente por lo que, en un cine "clásico", hubiera sido cortado en el montaje - o ni siquiera rodado. Graba y monta lo que habitualmente no se enseña (como la orina de una niña que se desliza sobre la tierra seca de un campo árido - ver Los motivos de Berta). El cineasta parece interesarse menos por lo que ocurre en la imagen que por lo que les ocurre a las imágenes y al tiempo del film. José Luis Guerin se interesa por lo que pasa cuando no pasa nada. (Mayer, 2010) 
Se podría hacer un glosario de imágenes esbozadas, que conforman el imaginario del autor. Estos hallazgos surgen del impulso de la intuición, son pequeños acontecimientos que se producen en los procesos de creación. Pero a veces el gesto trasciende su condición de aparente aleatoriedad azarosa, para mostrarse como imagen poética, denotando una realidad de nuestro mundo, que a menudo pasa desapercibida a la mirada.

Esta trascendencia del gesto bruto al poema visual, es tratada por Gaston Bachelard (1975). El filósofo se refiere a la creación literaria de la imagen poética, vinculando su autenticidad con el impulso de la imaginación:

La imagen poética es un resaltar súbito del psiquismo (...) surge en la conciencia como un producto directo del corazón, del alma, del ser del hombre captado en su actualidad (...) siempre es necesario un impulso sincero, un pequeño impulso de admiración para recibir el provecho fenomenológico de una imagen poética. La menor reflexión crítica detiene este impulso, situando al espíritu en posición secundaria, lo cual destruye la primitividad de la imaginación. (pp. 7, 8, 15)

Los bocetos que Guerín capta y recolecta, ocupan un lugar propio en su trabajo. En palabras de Gonzalo de Lucas (2011) “La conjetura, la ensoñación, la especulación daban paso a sus películas, que no sólo son búsquedas de lo que comúnmente llamamos imágenes -la representación fotográfica, física, de un objeto- sino de imágenes poéticas y asociaciones mentales o metafóricas $[\ldots] "$

Con esta actitud sensible, el director se adentra, en los terrenos del arte más intimista, el que se ejerce en la soledad de la imaginación, utilizando las herramientas simples pero profundas de la percepción de la imagen inédita, logrando pequeñas piezas etéreas, libres, que contienen la esencia de infinitas lecturas, repletas de evocaciones no sujetas a medidas de tiempo ni a circunstancia alguna, ni siquiera al ritmo de la narración. Gestos independientes, montados posteriormente siguiendo sus relaciones sutiles, desvinculándose así de la lógica lineal, del habitual lenguaje cinematográfico.

\section{El estimulante conflicto de Guest}

En el fondo Guest es la historia de un desplazado que busca nuevos caminos $[. .$.$] Guerin no quiere "reinventarse" a toda costa, como parece$ 


\section{Martinez Villegas - Guerin: Descubriendo una sintaxis posible}

estar de moda, y la transición le resulta lenta, dolorosa, contradictoria, lo que hace de Guest una experiencia apasionante para quien sepa ver esas dudas inscritas en cada plano, en cada paso de uno a otro. (Losilla, 2011)

Guest (J.L. Guerin, 2010), discontinuo diario de viaje, labor solitaria y artesanal, en el que el cineasta impregna de una mirada lírica cada plano documental que recoge, sirviéndose de transiciones poéticas, que hilan sutilmente la narrativa fraccionada. Las historias que componen Guest están conformadas en diferentes partes del planeta, en una constante tensión, entre la artificialidad de los festivales de cine a los que es invitado, y la autenticidad de los personajes marginales de las zonas periféricas de las ciudades que visita. En Guest la secuencia documental es a su vez imagen poética. Guest es la calle, la mirada, es ver y explicar el mundo a través de un objetivo, recogiendo el testigo de documentalistas de diarios filmados, como el lituano afincado en Nueva York, Jonas Mekas (con el que tiene un revelador encuentro en la propia película, que años después se materializa como correspondencia fílmica en la exposición Todas las cartas). Guerin recolector, percibe y capta pequeñas historias potenciales para un recorrido posterior.

Sus hallazgos visuales en Guest poseen la mirada sorprendida de los niños, la indiscreción del deseo, que irrumpe y delata sin pedir permiso, la fenomenología de lo pequeño, la captación de lo singular. Sorprendiéndose ante el fenómeno que observa y ante los paisajes humanos, desoladores o favorecidos, dentro de una favela o a través de un vaso que tiembla a bordo de un avión, en la presencia melancólica de un pato, atado en una calle decadente de La Habana, o en el reflejo del agua que se confunde con el mar, en el interior de un canal veneciano.

$\mathrm{Su}$ imagen poética es independiente de los temas que subyacen en la película: una mirada del mundo globalizado e injustamente repartido, el adormecimiento de las conciencias occidentales y el silencio de nuestras voces, que contrasta con la voz elocuente de las calles latino americanas. Personas que muestran sus vidas abriendo sus casas, relatando su particular visión de las cosas, predicadores con discursos similares en las diferentes partes del mundo, o la mirada de los niños, pura y sorprendida siempre, a pesar de la dureza de sus circunstancias.

Guerin escucha, a personas, objetos y fenómenos. Observa, reacciona y registra, evidenciando la realidad de los lugares que visita, y el contraste que su presencia misma provoca. 
La esencia del gesto grabado es explicada de forma sentida por Jonas Mekas en la película:

\begin{abstract}
(...) yo no elijo, respondo al momento. Reacciono a la vida. Voy caminando por las calles y decido: "Ahora debería filmar." Reacciono a lo que veo, no es una cuestión de pensar. Nada viene de aquí -señalando su cabeza-, viene de... Es automático. Es intuitivo... aleatorio, a veces. Un poco al azar. Azar... Y a ver qué pasa. El uso del azar también es una elección, por supuesto. Todo es elección y nada lo es realmente. Es de locos, dicho así. Está predeterminado. Crees que eliges, pero no creo que haya elección. Tú crees: "Esto es lo que yo elijo", pero ya ha sido predeterminado por las circunstancias, y por eso decides elegir eso. Algunas decisiones se toman aquí y algunas aquí -señalando cabeza y corazón-. Y otras se toman allí -señalando el cielo-. ${ }^{2}$
\end{abstract}

Las palabras del artista lituano nos traen las reflexiones de Bachelard. Desde aquí podemos mirar el movimiento y la causalidad que unifica el film. Todo se envuelve de esta manera de actuar: intuición, gesto y empatía hacia el objeto con el que interacciona. Consiguiendo que la cámara -agente condicionante situado entre el que graba y el grabado- sea casi invisible. Esta disposición es también la que facilita comprender los fenómenos que actúan como transiciones poéticas. Sirva para ilustrar el argumento, la breve escena de una niña sentada en el suelo, contenida en las secuencias grabadas en Palestina; el director baja la cámara hasta la altura de su mirada, pudiendo ver que las gallinas que pasan, son más altas que ella, recogiendo y haciéndonos partícipes de su punto de vista, evocándonos nuestra propia infancia. Este breve esbozo, sensible y poético anuncia el espléndido pasaje de los niños palestinos, que con su imaginación reconstruyen para la cámara la antigua escuela, sustituida por las ruinas del paisaje desolado en el que habitan.

El orden secuencial que podemos reconocer en Guest, se construye en función de dar forma de film a las escenas recolectadas. La relación entre las partes viene determinada por un guion, que se va manifestando de manera simultánea al descubrimiento de las historias que lo compondrán, y a los vínculos que existen entre ellas. Encontramos abundantes esbozos que nos presentan pequeños fenómenos - libretas de apuntes, soles y cielos variados, vistas difusas desde un tren en marcha, planos abstractos aéreos tomados en los aviones, reflejos de cristal o agua, miradas a través de los vidrios de las habitaciones, etcétera, actuando como transiciones de los fragmentos 


\section{Martínez Villegas - Guerin: Descubriendo una sintaxis posible}

documentales.

Si bien es cierto que estas imágenes ejercen de nexo entre las historias, es difícil distinguir entre poética y documental. Resulta trivial diferenciar los planos documentales centrados en la atención del sujeto grabado, de los hallazgos de una mirada, que por momentos abandona lo concreto, para entrar en lo sutil. El grueso de las secuencias contenidas en Guest, están impregnadas de esa atmósfera intangible. No es por tanto el uso del blanco y negro, el orden cronológico del diario de viaje o la herramienta (pequeña cámara de video digital), los únicos agentes que unifican y globalizan las diferentes partes del film; la mirada alerta al fenómeno y la disposición poética del autor, nos sugiere y conduce una trama posible dentro de la narrativa no lineal.

Para establecer los vínculos existentes entre las secuencias de este relato múltiple, el montaje toma un gran peso en la creación final. Imaginamos la difícil selección del material filmado (unas 150 horas recolectadas según el autor) y su relación interna, para facilitar que se revele el sentido último del film. Este es uno de los puntos de conexión con una de sus anteriores obras.

\section{El devenir de Unas fotos en la ciudad de Sylvia}

El material secuencial de imágenes fijas, utilizado en Unas fotos en la ciudad de Sylvia (J.L Guerín. 2007), marca una notable diferencia con el resto de obras del director, siendo su film más radical y experimental, pero también el más clásico en el sentido de indagar en el origen del cine, cuando la imagen aún carecía de movimiento. Sin embargo la condición solitaria de diarios de viaje (verdad o artificio pero diarios al fin y al cabo), compuestos a partir de gestos recolectados, la relaciona íntimamente con Guest, abriéndole un campo de trabajo más personal. Núria Esquerra (2008) productora del filme Unas fotos en la ciudad de Sylvia y de la videoinstalación Las mujeres que no conocemos presentada en la Biennale de Arte de Venecia 2007, escribe acerca de su colaboración con el cineasta en el montaje de la película:

El montaje ayudó a Guerin a ordenar sus ideas, ya que él piensa en imágenes y sonidos. De hecho, me parece que nunca ha escrito un guión estrictamente con palabras. En un principio, por tanto, esos montajes solo debían ser el germen de un guión o un borrador, unas notas preparatorias de ese film rodado en cine y con actores, que luego ha sido En la ciudad de Sylvia (...) Se trata de un procedimiento que, en 


\section{BRAC - Barcelona Research Art Creation, 2(2)}

principio, debería ser arcaico en el cine, sucesión de imágenes fijas, pero que está apenas explorado. El ritmo no está creado por el movimiento del plano o de los elementos dentro del encuadre, sino por la duración del instante detenido y sus relaciones con las otras imágenes fijas. El montaje se convierte en algo mucho más esencial. (p. 42)

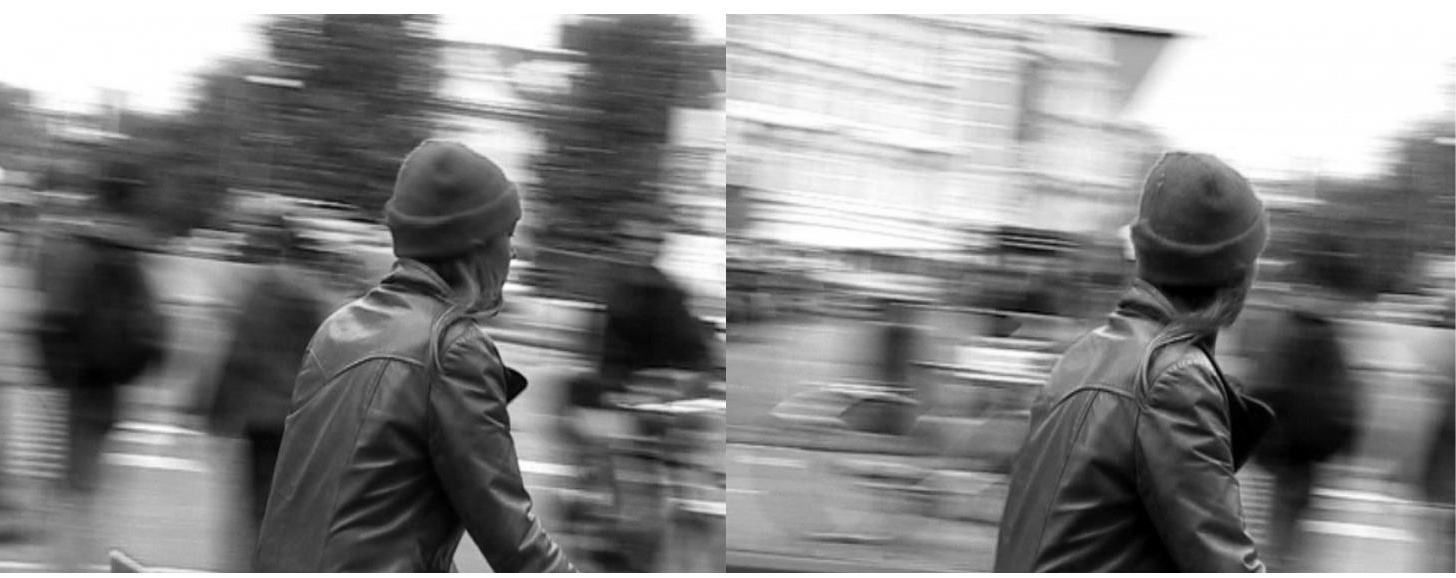

Figuras 1,2. Fotogramas de Unas fotos en la ciudad de Sylvia (J.L Guerín. 2007). Cortesía del autor. (C)

Unas fotos en la ciudad de Sylvia (figuras 1,2) es un ensayo fílmico, mudo y en blanco y negro, compuesto por una sucesión de fotografías, que son guiadas por relatos que orientan al espectador sobre su sentido, una recolección de textos y bocetos visuales, estructurados posteriormente en el montaje. Atípica obra del director si la comparamos con sus filmes más ficcionados. No obstante es una obra coherente dentro de la línea de Guest o de sus instalaciones de video. Aunque pueda leerse como el esbozo previo a La ciudad de Sylvia (2007), el estilo, la narrativa, el medio y la herramienta, actúan de puente entre sus películas y el lenguaje de sus exposiciones. En esta ocasión, la balanza se inclina hacia la experimentación con el montaje de imágenes captadas.

La película sitúa al espectador ante el proceso en bruto, desvelando la devoción por entrar en la intimidad de lo real y captar un instante de naturalidad. Utiliza el silencio, la consecución de imágenes y las intenciones ocultas, para conducir una narración incierta y seductora. Una serie de fotos fijas que son por sí mismas esbozos gestuales, que buscan una mirada sincera. 


\section{Martínez Villegas - Guerin: Descubriendo una sintaxis posible}

El cineasta nos invita así a entrar en la intimidad de su atelier, en su personal proceso creativo, obteniendo a cambio fuentes de futuras transformaciones. En las imágenes que conforman el film se encuentran las semillas, que posteriormente expande por proyección, en las dos instalaciones que realiza, ideadas para espacios expositivos.

Si relacionamos el conjunto de la obra cinematográfica de Guerin con su incursión en el arte contemporáneo, encontramos que Unas fotos... es una obra potencialmente muy importante del autor, ya que actúa como nexo de la expresión formal en sus instalaciones.

Entre el montaje del cine y el montaje en la instalación multipantalla existen grandes diferencias y a su vez estrechos vínculos de lenguaje. Tarkovski (1988) definió el montaje como una de las más importantes fases de la creación audiovisual; "es la relación del director con su idea, siendo la expresión de la forma definitiva de ver el mundo del director", relacionándolo con los vínculos que se establecen entre los elementos y con el sentido del tempo: "Su coordinación origina un cuadro rítmico único, una innovación orgánica creada por la sensibilidad temporal de su autor." (p. 148)

La lógica interna de la narrativa depende de su lenguaje interior, de la relación de las diferentes imágenes en movimiento. Este punto es común entre el cine, el videoarte o la instalación audiovisual, cada una de las áreas con sus particularidades. La primera exploración de Guerin en el espacio del arte contemporáneo, la exposición Las mujeres que no conocemos, se basó en una instalación multipantalla para el Pabellón de España en la 52a Bienal de Venecia de 2007, posteriormente expuesta en el CCCB (Centro de Cultura Contemporánea de Barcelona) en 2008.

La muestra fue la tercera parte de la línea temática desarrollada en el mismo año, que comenzó con Unas fotos en la ciudad de Sylvia (figuras 3, 4, 5, 6), seguida por En la ciudad de Sylvia (figuras 7, 8, 9, 10). La instalación fotosecuencial para la Bienal de Venecia, propuso un montaje diferente incluyendo el mismo material (figuras 11, 12, 13, 14, 15, 16, 17, 18), generando una construcción híbrida en el espacio dado; la fotografía en forma de proyección, planteaba al espectador una trama compleja, un recorrido por el diálogo que conformaban sus diferentes partes.

En el tipo de instalación que el cineasta plantea para las salas de arte, se suma el factor espacio y su relación con la imagen. La narrativa no lineal, expresada con una sola pantalla en el montaje cinematográfico y en su exposición natural, la sala de cine, es posibilitada en la instalación audiovisual de forma física, aplicando la trama a la experiencia del espectador paseante. 

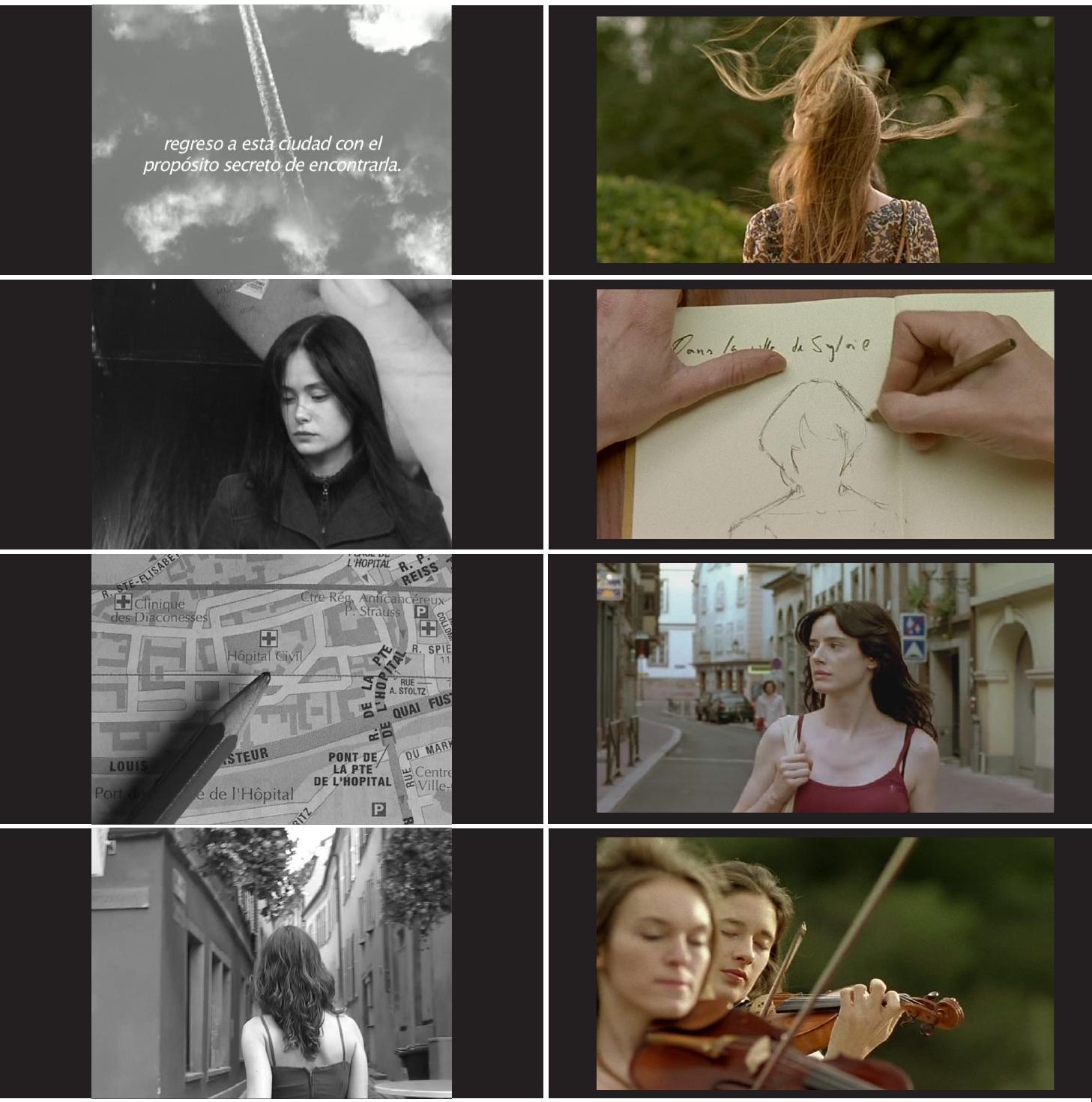

Figuras 3, 4, 5, 6. (Izquierda) Fotogramas de Unas fotos en la ciudad de Sylvia (J.L Guerín. 2007). Cortesía del autor. (C)

Figuras 7, 8, 9, 10. (Derecha) Fotogramas de En la ciudad de Sylvia (J.L Guerín. 2007). Cortesía del autor. (C) 
180 Martínez Villegas - Guerin: Descubriendo una sintaxis posible

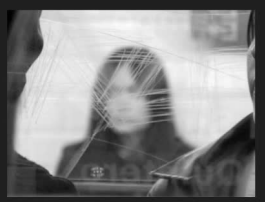

La imagen retenida
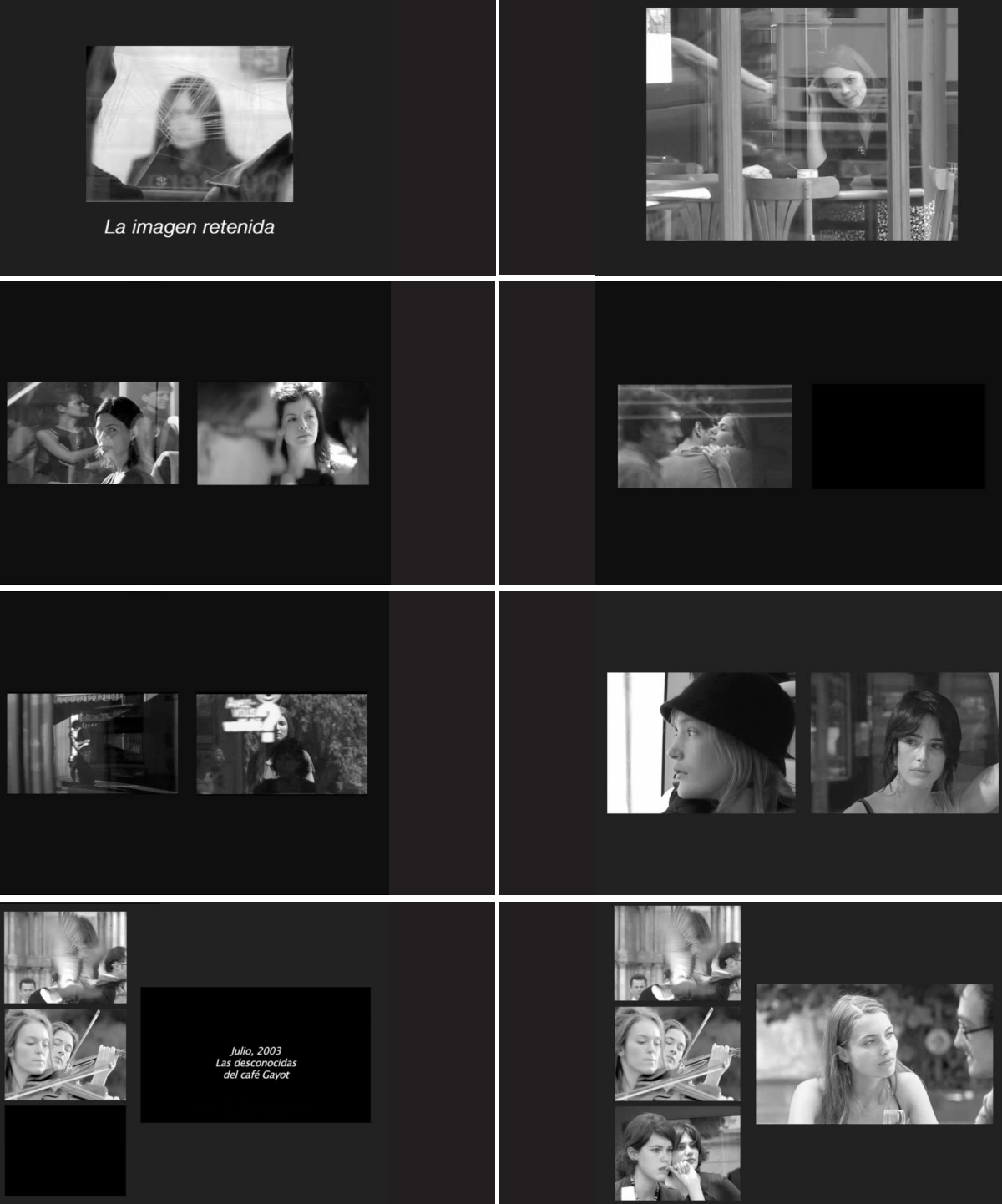

Figuras 11, 12, 13, 14, 15, 16, 17, 18. Montaje análogo (aproximación) de la Instalación Las mujeres que no conocemos. Filme en 24 cuadros. Pabellón de España 52a Bienal de Venecia 2007. (J.L Guerín. 2007). Cortesía del autor. (C) 


\section{Otra sintaxis posible}

Guerin se interesa por otras lecturas de su trabajo, que le permiten indagar en soluciones alternativas a la industria del cine para su imagen poética: “(...) voy descubriendo o pensando en una sintaxis posible, siempre con el propósito de utilizar estos espacios para explorar aquello que sé que en cine no podría, no me dejarían." 3

Sus historias abiertas adquieren un sentido diferente en la sala de arte. La bidimensionalidad de la pantalla da paso a un tipo de propuesta, que se acerca a las prácticas de video-artistas, que utilizan material cinematográfico propio o ajeno en sus obras. $\mathrm{O}$ a cineastas que no cómodos con la narrativa habitual del cine, desarrollan y exponen sus trabajos en el ámbito del arte contemporáneo, sirviéndose de un lenguaje que refuerza formalmente un tipo de relato complejo. El medio ayuda a conformar un tejido de solapamientos, estructurando fragmentos para encontrar la impresión de unidad, priorizando esta atmósfera, más cercana a la percepción humana y a la verdad del proceso artístico -que nunca es lineal- a una rigurosa lectura del guion.

Algunos autores que bien puntualmente o en exclusiva, operan por necesidad creativa en estos espacios de confluencia, realizan en sus procesos dos versiones de un mismo proyecto, pensadas para una doble salida; la sala de arte y el circuito cinematográfico. Es el caso de la artista y filmmaker ElijaLisa Ahtila (Finlandia, 1959) que respondiendo a las cuestiones de Doug Aitken declara:

[...] I make a work with moving images, I usually do both a film version and an installation version. The film version is distributed through festivals and on television, and the installation through galleries and museums. But if I think about my approach to the medium of the moving image itself, it's more as an artist. The important thing for me is to express myself through the medium. Only when I have to, do I think about the differences between the two fields, like when I try to get financing from the film world. It's then that I often realize how different my approach is. It's not always easy to find a common language. But fortunately there are people out there who are interested in the new developments going on in film narration $[\ldots]^{4}$ 


\section{Martínez Villegas - Guerin: Descubriendo una sintaxis posible}

Especialmente relevante es la aportación de Doug Aitken (California, 1968), video-artista con gran reconocimiento internacional en la actualidad, con su libro-manifiesto, compuesto por 26 entrevistas; Broken Screen. Expanding the Image Breaking the Narrative (Aitken, 2006). En su ensayo, Aitken analiza lo que ejerce en su carrera; la fragmentación de la narrativa en el cine, el videoarte y la instalación, recogiendo la opinión de cineastas y artistas, que tienen como factor común la deliberada no linealidad de sus obras audiovisuales. Robert Altman, Claire Denis, Bruce Conner, Gary Hill, entre otros, a través de conversaciones informales, desgranan las ideas, intenciones y necesidades de proceso, que hay detrás de la denominada expansión de la imagen.

En una aproximación a la contextualización de esta compleja práctica interdisciplinar, hay que nombrar al crítico Gene Youngblood (New York, 1942), que escribió uno de los primeros estudios de la ruptura de la narrativa fílmica convencional, acuñando el término Expanded Cinema (Youngblood, 1970), anticipando el potencial del medio, imbricándolo a la evolución de las nuevas tecnologías, y reclamando la necesidad de una nueva forma de cine para cambiar la percepción y la conciencia del espectador. Youngblood imbuido en el contexto de la época, atribuía al Cine Expandido un alcance redentor: "[...] La conclusión es que el arte y la tecnología del cine expandido suponen el principio de la vida creativa para toda la humanidad y, por lo tanto, una solución al llamado problema del tiempo libre." 5

Con cierta perspectiva, la artista e investigadora Esperanza Collado (2011) en su ensayo Paracinema. La desmaterialización del cine en las prácticas artísticas, emplea el término Paracinema, para definir el movimiento de aquellos autores, que han expresado aspectos propios del cine a través de otros medios. Según la autora, esta práctica no implica tanto la fractura del cine, sino su evolución hacia otras formas del arte. Se desmarca del término Cine expandido desarrollado por Youngblood diciendo:

Paracinema, en oposición al cine expandido, es la realización de la idea de cine a un nivel conceptual, experiencial y artístico. Se trata, en cualquier caso, de generar una experiencia cinemática desconectada, entera o parcialmente, de su aparato tradicional. (Contraportada)

En este sentido, a modo de ejemplo, son destacables los últimos trabajos del cineasta Peter Greenaway, muy vinculado con el arte desde temprana edad, formado como pintor, e interesado en reinventar el lenguaje cinematográfico 
y las posibilidades de la percepción de la imagen en movimiento. En 2009 y dentro del proyecto de gran envergadura Nine Classic Paintings, en el que imagina los procesos de creación y reformula a su manera, los planteamientos pictóricos de Velázquez, Caravaggio, Rembrandt, Rubens entre otros, presentó la multi-proyección The Wedding at Cana, inspirándose en el lienzo de El Veronés, Las bodas de Caná. La instalación se presentó por primera vez en el refectorio de San Giorgio de Venecia, espacio para el que fue creado originalmente el cuadro.

En un plano teórico, Alfonso Puyal (2012) en el artículo Cineastas en el museo, distingue hasta nueve formas de inclusión del cine en el ámbito expositivo: Introducción de películas en el museo; exposiciones que enfrentan la imagen en movimiento con la pintura; exposiciones divulgativas dedicadas a directores de cine; colectivas temáticas dedicadas a los dispositivos cinematográficos; apropiación del cine en el videoarte; trabajos cinematográficos hechos por artistas; obra plástica hecha por realizadores; correspondencias filmicas entre directores, y por último, cine de autor que realiza instalaciones por encargo del museo (pp. 104-119).

La segunda exposición de Guerin La dama de Corinto. Un esbozo cinematográfico (2011) (encargo al cineasta del Museo Esteban Vicente de Segovia), al igual que la primera, se sitúa en esa última definición que plantea Puyal.

En esta instalación el director pone en relación el ejercicio del cine con el origen de la pintura, tomando los textos de Plinio el Viejo en su Historia Natural. Guerin impulsa el planteamiento visual y conceptual, incidiendo en la confluencia entre la cinematografía y las artes plásticas. Y lo hace desde una imagen con un profundo significado convergente: una mujer, que ante la partida de su amado, decide trazar el contorno de su sombra en la pared, proyectada por la luz de una vela. La pintora originaria trabaja a partir del fenómeno de la proyección y no de la observación del modelo. En este mito originario, basa Guerin la confraternización entre la pintura y el cine, reforzando un argumento que ya formuló cuando fue invitado a la Bienal de Venecia, declarando sentirse legítimo heredero de la pintura, un arte extinto según el cineasta. La pieza principal de La dama de Corinto constaba del mediometraje Dos cartas a Ana, de 25 minutos y tres salas más que analizaban visualmente el concepto base, dividiéndolo en un total de 24 pantallas y proyecciones. La muestra contenía la dualidad entre imagen lírica y documental, con transiciones textuales que ilustraban la elaboración del mito originario al modo del cine mudo. Su visión cinematográfica se centraba 


\section{Martínez Villegas - Guerin: Descubriendo una sintaxis posible}

en generar el relato por secuenciación de pantallas, indagando en la dialéctica de la proyección, renovando los significados de sus piezas más intimistas, poniendo en relación la imagen y la configuración arquitectónica del espacio dado.

Jesús Martínez Clarà (2011) afirmaba al respecto de las imágenes contenidas en la exposición: "Las imágenes mudas de Guerin no quieren ser un instrumento al servicio de la narratividad, sino un valor por sí mismas, y eso exige del espectador máxima concentración en los detalles, atención casi litúrgica [...]” (p. 5). La cohesión y el interés de la trama que subyacía en la instalación dependía, al igual que en sus films, de las relaciones sutiles implícitas entre sus esbozos poéticos, en mayor medida de lo que los textos que actuaban de guía, trataban de aclarar.

Dentro de los proyectos curatoriales de cine expositivo, Guerin fue invitado a participar en la exposición colectiva Todas las cartas. Correspondencias filmicas, que tuvo lugar en el CCCB de Barcelona, desde octubre de 2011 hasta febrero de 2012, presentada un mes antes en la Casa Encendida de Madrid, teniendo su equivalente francés en el Centre Pompidou de Paris: Jonas Mekas / José Luis Guerin: Cinéastes en correspondance, Installation, en diciembre de 2012. La muestra, reunió varios intercambios fílmicos, compuestos por parejas de cineastas internacionales, como Isaki Lacuesta y Naomi Kawase; Albert Serra y Lisandro Alonso; Jaime Rosales y Wang Bing; Fernando Eimbcke y Yo Song Kim entre otros, siendo las cartas filmadas el tema argumental del proyecto. Los cineastas proponían bocetos cinematográficos, que evolucionaba el realizador receptor, partiendo del final que planteaba el autor encargado de arrancar la propuesta.

José Luis Guerin mantuvo su particular correspondencia con el poeta y video-artista lituano-norteamericano Jonas Mekas, recuperando en el arranque de la misiva su encuentro en Nueva York recogido en Guest. El cuidado blanco y negro del director catalán dialogaba con la imagen heterodoxa, entre lo familiar y lo amateur de Mekas. Un diálogo emocionalmente cautivador y formalmente dispar, entre dos autores que comparten el gusto por utilizar la cámara, como una parte de la memoria que atrapa momentos especiales, pero con diferentes métodos de creación, dos formas de entender el proceso. La imagen espontanea, diáfana de Mekas revela despreocupación por el montaje y pasión por la pulsión de grabarlo todo, haciendo de su actividad voayerística un modo de estar en el mundo, mirando la vida a través del objetivo. En su correspondencia, ambos dialogan sobre los hallazgos en las imágenes grabadas, la memoria y los procesos de creación. En este proyecto, Guerin 
contrasta la vertiente más autónoma de su modus operandi, con la actividad diaria de Mekas, uno de los artistas más respetados del cine experimental. El trabajo de Guerin contenía una refinada interpretación del encuadre, y el natural interés del cineasta por la coherencia de un montaje fragmentado. Es precisamente el montaje como agente estructural de los planos recolectados, uno de los argumentos centrales que comparten en su intercambio fílmico los dos autores; Guerin visita la añeja editing room de Mekas y responde, mostrando un plano en el que aparece su ordenador personal con el programa de edición de video, recalcando la importancia que la edición adquiere en un tipo de trabajo autónomo, en el que la imagen poética predomina sobre el argumento.

Fernando Canet (2013) orienta el proceso cinematográfico de Guerin, en la composición resultante de la tensión entre el azar y lo controlado, siendo "en la sala de montaje donde el material filmado se transfigura definitivamente en discurso, donde ese material resultado de llevar a la práctica la formulación cinemática I react to life, de Mekas [...] es finalmente ordenado dotándolo de sentido." (pp. 145-159).

El montaje aplicado ala instalación multi-proyección de sus dos exposiciones, exigía al cineasta además, enfrentarse al espacio, como factor determinante del relato, que proponían las diferentes proyecciones de fotografías o imágenes en movimiento. Los esbozos cinematográficos tomaban aquí entidad formal de piezas autónomas, siendo prioritario el diálogo y el acuerdo de su imagen poética; consigo misma por su expansión, seriación y relación entre sí, y con su tratamiento como objeto independiente modulable, y sobre todo con el espacio que las contiene y las vincula, logrando o no la percepción de un todo relacionado, complejo y rico, en la vivencia del espectador.

Atendiendo de nuevo al análisis que realiza Esperanza Collado (2011) del fenómeno de la expansión de la imagen cinematográfica, Guerin literalmente separa su cine del montaje habitual y su medio tradicional, lo deconstruye y lo recicla, encontrando una ubicación nueva con potencial capaz de multiplicar sus significados.

[...] la deconstrucción del cine y, en última instancia, su destrucción. El medio, sin embargo, no llega a destruirse a sí mismo como tal, sino que negocia su materialidad fenomenológica con las otras artes, formando un vínculo con ellas que las transforma para siempre. (p. 20) 
Rafael R. Tranche (2012) deja una cuestión en el aire con respecto a esta negociación; "[...] ambos discursos, ambos medios y sus ámbitos de contemplación parecen necesitarse mutuamente, están condenados a entenderse; la cuestión radica en dirimir en qué punto ha de producirse la intersección o la simbiosis" (p. 77).

Guerin no es una excepción como cineasta que mantiene una relación con el arte contemporáneo. Realizadores actuales como es el caso de Albert Serra (Girona, 1975), fue invitado para la $13^{\mathrm{a}}$ edición de la dOCUMENTA de Kassel, presentando Els tres porquets (2012), un retrato contemporáneo de Alemania, a través de los textos de tres personajes antagónicos de su historia reciente: Goethe, Hitler y Fassbinder, una película de 101 horas de duración, que se realizó en dos fases durante el evento, llegando al extremo de simultanear su montaje y su visionado. El Centre Pompidou de París ha acogido con la exposición La Carte Blanche la totalidad de la obra de Serra, durante los meses de abril y mayo de 2014, derivando la muestra de una de las Correspondencias filmicas del CCCB, entre Serra y el cineasta argentino Lisandro Alonso. Otro director incluido en esta exposición, Isaki Lacuesta, nacido en el mismo año y mismo lugar que su coetáneo Serra, es autor del documental El cuaderno de barro (2011) y del premiado largometraje Los pasos dobles (2011), ambos en colaboración con el pintor Miquel Barceló. Anteriormente se adentró en el espacio de la instalación, presentando entre otras intervenciones, De cos present (2012), instalación para siete pantallas, dentro del proyecto Arts del moviment, del Centre d'Arts Santa Mònica de Barcelona.

El Museu d'Art Contemporani de Barcelona (MACBA) en 2012, realizó la exposición Series militares sobre la obra del cineasta Aleksandr Sokurov (Podorvikha, Siberia, 1951), autor de la aclamada El arca rusa (2002) y Fausto (2011). Por su parte el MOMA de Nueva York en 2007, dedicó una retrospectiva a la obra del director Pere Portabella proyectando su largometraje Die Stille vor Bach (2007). La sensible y visualmente deslumbrante película de José María de Orbe, Aita (2010) fue también programada dentro del Documentary Fortnight: MoMA's Festival Nonfiction Film en 2012, y un año antes en la Tate Modern de Londres.

Se podrían nombrar un buen número de cineastas en la actualidad, que son atraídos por los museos. A todos les une una mirada particular, una forma distintiva de entender la imagen fílmica, el sentido del silencio y del tiempo. Obras que por su configuración estética y temporal, pueden funcionar con cierta independencia. 
Un apreciable proyecto comisarial que mostraba la mirada del videoarte hacia el cine, fue El efecto del cine. Ilusión, realidad e imagen en movimiento. Sueño-Realismo, CaixaForum Barcelona-Madrid (2011), en el que se exponían las obras de video-artistas que en su práctica, establecían espacios de encuentro con la cinematografía. El proyecto analizaba el cine como fenómeno de la cultura visual, dando coherencia temática a las dispares aportaciones, profundizando en conceptos como la representación del sueño y los estados oníricos, las realidades subconscientes y sus estados de percepción. Las dos exposiciones colectivas contaron con la particular visión cinematográfica de relevantes artistas como Julian Rosefeldt, Andy Warhol, Douglas Gordon, Bruce Conner, Rodney Graham, Christoph Girardet, entre otros.

Los video-artistas que se sitúan en espacios de confluencia con la cinematografía, tratan la materia fílmica como un componente esencial dentro del tejido del proceso. Es el caso de aquellos que elaboran su propia imagen cinematográfica -véase la obra de artistas como Mattew Barney (California, 1967) o Shirin Neshat (Irán, 1957)- o los que se apropian de material icónico - es el caso de notables obras de Nicolás Provost (Bélgica, 1969) o Douglas Gordon (Escocia, 1966)-. Cuando esta heterodoxa disciplina, se mezcla con el factor espacio -significativo el trabajo de la artista Pipilotti Rist (Suiza, 1962) o el propio Doug Aitken-. O bien se proyecta sobre objeto entrando en el ámbito escultórico - Win Geleynse (Holanda, 1947) o Tony Oursler (USA, 1957)-, la imagen en movimiento pasa a ser un factor del conjunto que elabora el discurso, generando una trama que posibilita el recorrido y la experiencia perceptiva del espectador.

El video-artista Isaac Julien, (Londres, 1960) estudió pintura y cine en St Martin's School of Art. En la actualidad, su trabajo es uno de los más interesantes exponentes, del comportamiento de la imagen en movimiento en la sala de arte. En su última instalación Playtime (Victoria Miro Gallery, Londres, febrero de 2014), siete proyecciones a la vez, ofrecen un visionado múltiple de tres narraciones interconectadas, rodadas en Londres, Reykjavik y Dubai. En las escenas se pueden encontrar diferentes miradas simultáneas de un mismo fenómeno. El ritmo del filme o de los filmes contenidos, compuestos de relatos cruzados por el concepto subyacente, se ve favorecido por su extensión formal. El tema de fondo, la globalización del capital y de las personas, y la permanente sensación de movilidad, se refuerza formalmente por la diversidad de puntos de vista de la multi-pantalla.

La utilización durante el proceso de creación, del solapamiento de capas conceptuales y formales, como son los significados contenidos en la imagen 


\section{Martínez Villegas - Guerin: Descubriendo una sintaxis posible}

en movimiento en su relación entre sí, y con el espacio u objeto sobre los que se proyecta, forma parte del trabajo habitual de los autores que operan en estos terrenos de encuentro. Trabajos que son en último término, pensados y adaptados en ocasiones para espacios exteriores, y en general para el cubo blanco de la sala de arte.

Una de los aspectos que provoca la fricción en los encuentros confluyentes entre el cine y el arte, podría ser esta condición; el empleo del espacio expositivo, es decir, el conocimiento de la relación entre las sinergias del contenido y el contenedor. Este es un campo extensamente estudiado por el arte contemporáneo, al que los cineastas se enfrentan dentro del desarrollo del film, pero no en la exhibición de su trabajo. Una parcela con sus reglas y lenguaje propios, como todos los ámbitos de la expresión artística, capaz de multiplicar y potenciar el valor de la imagen poética, pero también de diseminarla y restarle su capacidad de síntesis o unidad.

En la entrevista con el director, contenida en el presente artículo, Guerin opina sobre esta fricción:

[...] hay un gran analfabetismo entre unos y otros, están en compartimentos estancos, no se conocen [...] Muchos artistas sienten desdén hacia el cine, como si no fuera algo serio, y a veces pecan de una ingenuidad extraordinaria porque hay cosas que el cine ha resuelto hace muchísimo tiempo. Y también a la inversa, es decir, hay cineastas que te miran muy raro por haber intervenido en el espacio del arte [...] Son espacios que se comunican poco, es muy raro y muy anómalo. ${ }^{6}$

\section{Conclusiones}

Guerin ensaya con la multi-proyección en salas de arte, lo que dentro de la industria del cine le es inviable. Resulta esta práctica una vía propicia para presentar su manera de concebir la cinematografía, que por su particular configuración del tiempo, la imagen y el montaje, deviene en narrativas no lineales. Su experimentación en la instalación audiovisual, viene a ser otra forma de montaje, en la que formalmente la narrativa se rompe y a la vez se unifica en su percepción espacial, dando coherencia poética, visual y argumental a un conjunto de esbozos, creados expresamente para la exposición, o bien recuperados de material anterior. Gestos que en Guest, o -en forma de fotografías fijas-, en Unas fotos en la ciudad de Sylvia, son ordenados secuencialmente. 
Los caminos abiertos, planteados por el director en sus exposiciones; Las mujeres que no conocemos y La dama de Corinto, guardan una estrecha relación con sus películas más personales, posibilitando una doble salida a su imagen poética; en el terreno de la industria del cine y en el del arte contemporáneo. Este hecho le sitúa en el umbral de los espacios de hibridación, en el que se encuentran otros artistas en la actualidad, que fluctúan entre los dos ámbitos. Autores que encuentran en estas experiencias confluyentes un lugar coherente, para la expresión de una multiplicidad que compone un todo, más cercana a la manera en la que percibimos nuestro entorno que el relato lineal, implicando también una invitación al espectador, a participar en la complejidad e incertidumbre inherente al proceso de creación.

\section{Agradecimientos}

Este artículo se enmarca dentro del programa FPU (Formación del Profesorado Universitario) del Ministerio de Educación, Cultura y Deporte, desempeñado en la Facultad de Bellas Artes de la Universidad de Barcelona.

Especial agradecimiento a José Luis Guerin y Núria Esquerra por su amabilidad y disponibilidad.

\section{Notas}

${ }^{1}$ Diccionario de la lengua española (DRAE) 22. ${ }^{\text {a }}$ Edición, publicada en 2001

${ }^{2}$ Mekas, Jonas. Declaraciones contenidas en Guest, José Luis Guerin 2007.

${ }^{3}$ Guerin, J.L. Declaraciones tomadas de la entrevista contenida en el presente artículo. Barcelona 11 de Junio del 2012

${ }^{4}$ Entrevista de Doug Aitken a Elija-Lisa Ahtila, contenida en: Broken Screen. Conversations with Doug Aitken. Expanding the Image Breaking the Narrative. 2006 D.A.P./Art publishers. Nueva York. ISBN 1-933045-26-4. p. 18

${ }^{5}$ Youngblood, Gene. Cine Expandido. EDUNTREF. Buenos Aires, 2012. p. 59. Traducción de la edición Expanded Cinema. Editorial: EP Dutton. New York, 1970.

${ }^{6}$ Guerin, J.L. Declaraciones tomadas de la entrevista contenida en el presente artículo. Barcelona 11 de Junio del 2012

7 El director habla sobre la exposición Series militares de Aleksandr Sokurov (2012), en el Museu d'Art Contemporani de Barcelona (MACBA)

${ }^{8}$ Guerin se refiere al Jeonju Digital Project, dentro del festival de cine coreano Jeonju International Film Festival (2011)

${ }^{9}$ El cineasta menciona a André Bazin en ¿Qué es el cine? I. Ontología de la imagen fotográfica. p. 29: "[...] la fotografía no crea como el arte Ia eternidad, sino que embalsama el tiempo; se limita a sustraerlo a su propia corrupción. En esta perspectiva, el cine se nos muestra como la realización en el tiempo de la objetividad fotográfica." 
190 Martinez Villegas - Guerin: Descubriendo una sintaxis posible

\section{Referencias}

Aitken, D. (2006). Broken Screen. Conversations with Doug Aitken.

Expanding the Image Breaking the Narrative. Nueva York. D.A.P./Art publishers, 18.

Bachelard, G. (1975). La poética del espacio (2a ed.). México D.F. Fondo de Cultura Económica, 7, 8, 15

Bazin, A. (2001) ¿Qué es el cine? Madrid. Ediciones RIALP, 29.

Bresson, R. (1979). Notas sobre el cinematógrafo (2 $2^{\mathrm{a}}$ ed.). México D.F.

Ediciones Era S.A., 10.

Canet, F. (2013). La fricción entre lo azar y lo controlado en el cine de José

Luis Guerin. Archivos de la filmoteca 72, 145-159.

Collado Sánchez, E. (2012). Paracinema. La desmaterialización del cine

en las prácticas artísticas. Madrid. Trama editorial y Fundación Arte y

Derecho, contraportada, 20.

De Lucas, G. (2011, 30 de Marzo). Los ojos frente a la cámara. Cultural La vanguardia, p. 3.

Esquerra, N. (2008). A propósito del montaje de "Unas fotos en la ciudad de

Sylvia". Libreto contenido en la edición del DVD, 42.

Losilla, C. (2011). Donde ya no estamos. Cahiers du Cinéma España, $N^{o} 42$, 24, 25.

Martinez Clará, J. (2011, 30 Marzo). La dama de Corinto. Ut pictura kinesis. Cultural La vanguardia, p. 5.

Mayer, M. (2010). Le temps des fantômes. Approche de l'oeuvre cinématographique de José Luis Guerin. Tesis doctoral. (Traducción al castellano). Universitat Pompeu Fabra y Aix-Marseille Université, 409. Puyal, A. (2012). Cineastas en el museo: José Luis Guerin. Archivos de la Filmoteca 69, 104-119.

Tarkovski, A. (2008). Esculpir en el tiempo. Reflexiones sobre el arte, la estética y la poética del cine $\left(9^{\mathrm{a}}\right.$ ed.). Madrid. Ediciones RIALP, S.A., 148.

Tranche, R. (2012). De la pantalla al lienzo: Cine proyectado y cine expuesto. Archivos de la filmoteca 69, 74-77.

Youngblood, G. (2012). Cine Expandido. Buenos Aires. EDUNTREF, 59. Primera edición: Expanded Cinema (1970). New York: E. P. Dutton \& Co. 
Juan Martínez Villegas: Estudiante de doctorado y becario de Investigación FPU. Departamento de Escultura. Universidad de Barcelona.

Contact Address: Facultad de Bellas Artes. Universidad de Barcelona. Departamento de Escultura. c/ Pau Gargallo 4, 08028 Barcelona (España). E-mail address: juanmartinezvillegas@gmail.com

\section{Anexo}

\section{Entrevista a José Luis Guerin}

Plaza de Sant Pere, Barcelona, 11 de junio de 2012.

- JMV. Pregunta: En tu segunda instalación audiovisual, expusiste en el Museo Esteban Vicente de Segovia con "La dama de Corinto. Un esbozo cinematográfico", una videoinstalación o cine fraccionado, en la que proponías un espacio de confluencia a partir de imágenes en movimiento. ¿Empiezas a preocuparte por el espacio expositivo?

- JLG. Respuesta: Sí, es curioso porque el viento sopla donde quiere siempre, yo nunca había pensado si nadie me lo pide, entrar en el sector del arte, de la videoinstalación, incluso era bastante escéptico con estos territorios. La cuestión es que me lo han pedido más de una vez, y voy descubriendo o pensando en una sintaxis posible, siempre con el propósito de utilizar estos espacios para explorar aquello que sé que en cine no podría, no me dejarían.

La primera experiencia fue para el Pabellón de España en la Bienal de Arte de Venecia 2007 con Las mujeres que no conocemos. Lo que pensé es; voy a utilizar esto para experimentar mi propio medio, que es el cine, desde las nuevas posibilidades que te da el espacio expositivo. De entrada creo que el espectador de un espacio de arte es esencialmente un flâneur, un paseante. En la medida en que el espacio de los cines, cada vez más hostil en términos de exhibición pura, el museo tiene también esa función estrictamente cinematográfica de 


\section{Martínez Villegas - Guerin: Descubriendo una sintaxis posible}

mostrar aquello que no se ve, donde no llegan las salas de cine. En principio pensé que había que respetar la naturaleza de ese paseante, al que no le gusta detenerse porque frustra su expectativa de recorrer un espacio, por tanto pensé una forma de secuencialidad desglosada en el espacio, intentando que el movimiento esté más en el espectador que en las pantallas. Lo que me sale más natural es la imagen en términos de blanco y negro, y siempre he querido hacer una película muda. Atendiendo a los legados originarios del cine. Esos que en las salas de cine no puedes explorar, sin embargo en las otras salas tienes una posibilidad, que es esta paradoja de utilizar el arte del futuro para pensar tu pasado más remoto, en este caso la fotografía secuencial. Ésta es una tradición de Étienne Jules Marey y Eadweard Muybridge, una foto tras otra en blanco y negro muda y La Dama de Corinto que está más atrás todavía de la fotografía, antes, los pintores de la Escuela Helénica, cuyas pinturas han desaparecido. En la medida en que mi medio, el cine está en trance de desaparecer, tiene necesidad de ponerse en relación, de sentirse parte de una trama.

- JMV. Hablando de "La Dama de Corinto". Era interesante la metáfora de la silueta en la pared desde la proyección. Tú planteabas que el cine tiene una herencia de la pintura, sin embargo la sombra que le servía para dibujar la silueta de su amado, era un símil a lo que luego hacías en la sala fijando una proyección de luz. Esto también denota una relación con el espacio escultórico.

- JLG. Cuando este museo de pintura me invitó a hacer algo, yo pensé en ese mito originario, en el que se encuentran el origen de la pintura o el del cine, como origen mítico. Al precisar esa primera pintora una sombra desde una proyección, ahí está el cine. Por otro lado, está planteándose constantemente ese conflicto entre dimensiones espaciales, tal como tú lo planteas, el espacio de la pintura y el espacio de la escultura. Y esa tensión latente, secreta, es la que rige toda la trama de la exposición. De un lado es lo que lleva a fraternizar íntimamente pintura y cine, la condena o la cualidad de esa bidimensionalidad que nunca han aceptado ni uno ni otro medio, hasta la pintura moderna.

- JMV. Pero en el momento en el que haces una fragmentación de la narrativa estás renunciando de alguna forma a la bidimensionalidad.

- JLG. Efectivamente, estoy tensándola de distintas maneras, una con la arquitectura, la imagen plana cuestionada con saltos de pared, una imagen bidimensional y sin embargo violentada con la arquitectura, es algo que me gusta mucho, si me invitan más veces a museos pienso seguir jugando con ello. Y de otro lado con la relación en el espacio ante las pantallas. Había una 
sala en la que una muchacha contemplaba un cuadro y acababa volviéndose al espectador, mirando no a ti sino a lo que había detrás, que eran las otras proyecciones, y se creaba una relación de plano contra plano en el espacio. Es decir que abre otra relación entre las pantallas, no son sólo los planos que se suceden temporalmente sino cómo se relacionan en un espacio.

- JMV. Y ¿por qué piensas que un cineasta despierta interés en el mundo del arte contemporáneo?

- JLG. Según me dijo el comisario de Venecia, le gustaban mis películas, pero me llamó por una intervención mía en el 2006 creo, en la que me invitaron a hacer algo en las páginas interiores del cultural de La Vanguardia. Hice un juego con fotos, en la dirección con lo que llevaba haciendo con las fotos mudas de Unas fotos en la ciudad de Sylvia. Y ese juego le hizo pensar en que podía hacer algo más, fue una gran sorpresa. Creo que era únicamente por esto, a mi me gusta mucho la pintura, soy ferviente paseante de museos de pintura, pero no creo que tuviera noticia de esto.

- JMV. ¿No crees que de alguna forma tu cine tiende lazos, más o menos visibles con el arte?

- JLG. Pues será, me es difícil ponerme en su punto de vista pero sí, seguramente en algunas películas mías como Tren de sombras, hay más diálogo con la pintura.

- JMV. ¿Quédiferencias crees que hay entre el pensamiento cinematográfico y el pensamiento video-artístico?

- $J L G$. En España es muy notable, porque hay un gran analfabetismo entre unos y otros, están en compartimentos estancos, no se conocen, esto en Francia no es así. Muchos artistas sienten desdén hacia el cine, como si no fuera algo serio, y a veces pecan de una ingenuidad extraordinaria, porque hay cosas que el cine ha resuelto hace muchísimo tiempo. Y también a la inversa, es decir, hay cineastas que te miran muy raro por haber intervenido en el espacio del arte y les parece que eres un pijo (risas), por aceptar una invitación en ese otro espacio. Son espacios que se comunican poco, es muy anómalo. Diríamos que probablemente sería que el videasta buscaría su espejo no en el cine, sino en otras fuentes del arte contemporáneo esencialmente.

- JMV. Me refería a la mirada. ¿Esa mirada no crees que es común?

- JLG. Yo creo simplemente que tiene que ver con una conciencia de tus medios, y esa conciencia se hará visible en el modo de mirar, de encuadrar, de montar, como enunciador de una película. Pero es la conciencia de una cierta memoria y un diálogo con tus medios. Un diálogo que no tiene porqué manifestarse con pesados desarrollos teóricos, simplemente está en el modo 


\section{Martínez Villegas - Guerin: Descubriendo una sintaxis posible}

de encuadrar. Tienes una cierta idea de cine o no, lo ves en los trabajos si está presente. Es verdad que eventualmente aparecen, cineastas que no han visto mucho cine, que han recogido una sensibilidad muy especial de los signos de la modernidad de su medio. Tiene que ver con esto, no tiene nada que ver con las herramientas empleadas. Mi película Guest está hecha con una cámara pequeña. En ningún caso tiene que ver con la tecnología, la tecnología es un falso problema, se habla demasiado de tecnología, y lo que importan son las ideas.

- JMV. ¿No crees que en Guest hay varias piezas que se acercan a un lenguaje video-artístico y que podrían ser autónomas? Es decir, es un trabajo en el que hay un hilo, pero no hay un hilo muy evidente, es más bien sutil, $y$ dentro de ese mismo trabajo hay varias direcciones, hay una imagen muy poética, pero hay otra que es más... ¿de captación del mundo quizás? O de una visión del mundo.

- JLG. Pensaba en el libro de Marco Polo, una Descripción del mundo. Tú me dices.. como una pieza de videoarte... ¿eso que querría decir? Una cosa que de entrada me hace muy precavido con el videoarte es la dispersión, con esto he sido muy reticente. A mi me gusta mucho la concentración de la unidad, la pantalla, la oscuridad y casi nunca me he creído la retórica esa de la interactividad, por el hecho de que haya más pantallas es más interactivo, o que el espectador use botones para interactuar, no es verdad, es una falsa ilusión. Casi todas las instalaciones que juegan con la ilusión de la interactividad son sumamente alienantes, se ha hecho mucha retórica con esto, es muy frustrante. En el museo las piezas de videoarte y la instalación pueden tener distintas estrategias con el tiempo, tiempos aleatorios, captas unos segundos y puedes tener cierta idea de la propuesta en las imágenes, pero la mayoría de veces no es así, la mayoría tienen un continuum temporal de desarrollo y esto favorece la dispersión, tener ocupado al ojo, el mirar sin ver. Eso se da mucho en el diseño del espacio que podría ser muy próximo a lo publicitario. Esto me irrita mucho. No hace mucho fui al MACBA a ver unas películas de Sokurov. ${ }^{7}$

Estuve una hora y media, completamente solo, pero a lo largo del visionado iban asomando un minuto, medio minuto, tres minutos, al menos 50 personas. Habría que informar al espectador de cuál es el planteamiento temporal de los trabajos. Porque a veces es una película normal, es documentación. Están muy confusos los espectadores, como zombis en la oscuridad mirando a un lado y a otro, sin saber cómo relacionarse con lo que ven. Esto me angustia mucho. En la Dama de Corinto planteaba empezar con una proyección de casi media hora que daba unas bases y después loops brevísimos con cuadros a veces en 
movimiento pero que no implicara una intención, porque el espectador es muy perezoso. Seguramente lo es igual con los cuadros. Al no tener una dimensión temporal, la gente pasea frente a ellos pero probablemente la mayoría de espectadores no han visto nada, han paseado la mirada sobre la superficie de muchos cuadros sin haber visto nada. Pero bueno, la dimensión temporal de los audiovisuales evidencian ese contrasentido. El espectador la mayoría de casos no es un espectador, es un consumidor que mira sin ver.

- JMV. Hemos hablado del aspecto formal del video. Al hacer esta comparación con Guest, me refería a la poesía contenida en las imágenes, que luego se enlazan un a con otra pero siguen siendo independientes. Un pato en la Habana, o un reflejo bajo un canal en Venecia. Son pequeñas piezas que comparo con el videoarte, en el sentido contrario a la dispersión: el poder de la poética concentrado en una imagen muy esencial.

- $J L G$. Sí, tiene que ver mucho con la fotografía.

Yo intento en cada proyecto, en cada película, hacer algo completamente distinto, y utilizando una forma de producción muy específica. Siempre lo he hecho así, me gusta recordar que Flaherty, cuando hizo Nanook el esquimal, a quien acudió no fue a una productora de cine, sino a una compañía de pieles. No sabían nada de cine, por eso le dejaban libertad absoluta. Siempre ante las características de una nueva producción me pregunto qué puedo hacer con esa forma de producción, que no puedo hacer en otro espacio, es lo que me da singularidad intrínseca. En Tren de sombras la presencia de Pere Portabella como productor, me liberaba del servilismo del guión y me posibilitaba hacer una película de ficción pensada de otra manera. En En construcción lo que me daba la universidad era la posibilidad de trabajar con estudiantes, con los que podía estar conviviendo periodos muy largos en un espacio, algo que con técnicos veteranos hubiese sido imposible. Cada película es hija de una experiencia única y singular. Las de los museos igual, busco un objeto que sólo es posible en esa experiencia. En Guest me propuse este pacto, un año yendo a todas partes con la camarita, y sí es cierto que lo que me atraía como principio estético era esa idea de módulos independientes y ciertas rimas subterráneas que dan una composición global. Esto hace que no se puedan cambiar de orden. Pensaba con los módulos, que igual se podía hacer algo como en Rayuela de Cortázar, pero me parece que no, que es más aparente que real, o sea que si lo ves con calma hay muchas más leyes de progresión de las que parecen, aunque cada bloque efectivamente sea abierto.

- JLV. Encuentro que hay unas relaciones, que ya me dirás si estaban en ti, entre el funcionamiento de "Guest", "La Dama de Corinto" y "Unas fotos en 


\section{Martínez Villegas - Guerin: Descubriendo una sintaxis posible}

la ciudad de Sylvia”, creo que está todo interconectado.

- JLG. Ahora que lo dices, soy consciente de Las mujeres que no conocemos y Guest, que aunque sean cada una con sus materiales, pero sí que son de la misma naturaleza. Hay una cosa que lo une todo, tienes razón, que es la herramienta, la modestia de la herramienta y el hecho de que sean piezas pensadas como soliloquios. Eso quizá ha sido un cambio muy importante que me han dado las nuevas tecnologías, el hecho de que se difuminan las fronteras entre un trabajo y otro. En Los motivos de Berta e Innisfree, clausuraba una experiencia y pasaba un largo periodo de tiempo en el que empezaba algo completamente distinto. El hecho de tener las herramientas de trabajo en casa, trabajar con una pequeña cámara.

- JMV. ¿Editas en casa?

- JLG. Sí. El tener las herramientas en casa te da otra forma de pensar. Por libre que te sientas en una moviola o un laboratorio trabajando con otra persona, siempre tienes el sentimiento de que debes rentabilizar el tiempo, que no es un tiempo solo tuyo sino que hay otra persona, incluso un espacio que se ha de rentabilizar, esto cambia completamente, aunque no seas consciente cambia radicalmente el modo de pensar. Te levantas por la mañana, con el café te acercas a tu mesa de trabajo. Me lo he puesto en mi escritorio, en el espacio en el que escribo; y escribes imágenes. Captas una imagen, la introduces en la memoria de tu ordenador, la relacionas con otra imagen que ya tenías tiempo atrás, la guardas en una carpeta, no haces nada con ello. Meses después hay una tercera imagen que se pone en relación con eso. Es decir que sería exactamente el modo de pensar de un escritor, el hecho de tener un esbozo, guardar en una carpeta, poner en relación una idea con otra.

- JMV. O de un artista.

- JLG. Sí, según con que formas de arte.

Esa superación de unas barreras industriales que a veces me cuesta recordar si esa imagen estaba en las mujeres de La ciudad de Sylvia, o en Las mujeres que no conocemos o en Guest. Hay una interrelación, se hace más magmático todo. Es así, pero son los trabajos que he hecho solo, lo que yo llamo soliloquios, porque eres tú y tus circunstancias.

Yo siento mucho el deseo también de recuperar el trabajo en equipo, me gustaría que la siguiente película fuera de equipo, de envergadura, pero tengo esas dos opciones, el trabajo con equipo y el trabajo más de soliloquio, en cuyo caso, sí piensas en que hay una unidad final, que es tu pensamiento especulando con imágenes distintas.

- JMV. ¿Pero no crees que es muy distinta una cosa de la otra? 
- $J L G$. ¿El trabajo en equipo y el trabajo en solitario?

- JMV. Sí y el resultado incluso, el proceso y el resultado. O sea, "Guest", no tiene nada que ver con "En la ciudad de Sylvia".

- JLG. Pero "En la ciudad de Sylvia" sí tiene que ver con "Unas fotos en la ciudad de Sylvia".

- JMV. ¿Fue posterior no? "La ciudad de Sylvia" a "Unas fotos..."

- $J L G$. Sí. Aunque luego fantaseaba, a veces cuando estoy preocupado con el modo de vivir y tal, con hacer una versión de En la ciudad de Sylvia pero fotográfica, convertirla en una fotonovela (risas). Me hubiera gustado hacerlo, incluso a veces pienso, si me quedo sin dinero y me arruino, puedo hacer adaptaciones fotográficas de películas o reinventar las relaciones distintas con fotos de películas que ya he hecho.

- JMV. En "Unas fotos...", hay captación de verdad, sin embargo en "La ciudad de Sylvia" hay actores. Partiendo del principio que Bresson apunta en sus Notas sobre el Cinematógrafo (1979), sobre los modelos y los actores, son cosas totalmente opuestas ¿no?

- JLG. Bueno, a mi me gusta confundirlas, en Unas fotos... capté una chica que doblaba una esquina, que tenía guardada, fue una de las primeras capturas instantáneas, luego hay amigas mías también que obedecen mis instrucciones. Es decir que es una construcción, es un artificio. El hecho de que utilice la primera persona del singular en los textos confunde a muchos, como si fuera una experiencia, un diario de verdad mío.

- JMV. Lo había llevado por ahí, pero no por los textos sino por las imágenes.

- JLG. En En La ciudad de Sylvia, hay mucha captura real también. En la secuencia de la terraza que para mi es la más importante, la mayoría de personas no son actores. Aquí les planteo una situación, un motivo de diálogo, les cuento una historia horrible, les creo la situación, espero y me gusta ver qué pasa, como cambian sus expresiones, es decir que cuando hago una ficción voy a buscar pactos con lo aleatorio, con lo accidental que me transfiere, y cuando la materia prima es azarosa por naturaleza en la realidad, busco procedimientos para componer, para estructurar, estilizar esa materia prima.

-JMV. Y hablando de Bresson. ¿Anhelas algo que te gustaría aprehender para tu trabajo de la obra de Bresson?

-JLG. No. Está bien que sea fundamental para mi educación como espectador, para mi crecimiento sentimental incluso, lo que me ha revelado su escritura, para una sensibilidad que no tendría si no hubiese visto sus películas, pero es un sedimento. Ser como Bresson sin ser él, te lleva seguro al fracaso. 


\section{Martínez Villegas - Guerin: Descubriendo una sintaxis posible}

-JMV. Seguro. Me refiero a algún aspecto que te gustaría tener... esto me arrebata y me encantaría que algún día me saliera propio... Si es que hay algo.

-JLG. ...Su independencia como cineasta. Ser como una roca frente al oleaje del cine, manteniéndose como un islote. Eso sí que me gustaría, pero es más de índole práctica. Y yo no lo hago en absoluto.

-JMV. Bueno, creo que un poco sí...

-JLG. Sí, algo sí. Pero cuando voy a algún programa de televisión o de radio, pienso que él nunca hubiese ido (risas). Yo le conocí, ¿lo sabías?

-JMV. Sí, te lo oi en una entrevista.

-JLG. ¿En el bonus de Lancelot du Lac?

-JMV. Sí, eso es. ¿Y qué tal la experiencia?

-JLG. Yo era muy joven y hablaba muy mal francés, decía lo que entendía. Tenía ese lado muy privado. No daba entrevistas a periodistas pero si tenía la garantía de que no eras periodista y te gustaba mucho su cine, le alagaba. En el bonus, contaba que como espectador, el final de Lancelot du Lac, en el que con estrépito, caía la última armadura, era como un Haiku, similar a cuando los monjes budistas hacían ver la iluminación desde algo muy simple, como el croar de una rana.

Siempre pienso que mi despertar en el cine, mi estadio de madurez, tal vez fue esa armadura cayendo. Por eso te digo que no se trata tanto de copiar una estrategia, sino que la deuda que tengo con él, es el cine, no los procedimientos o los trucos.

-JMV. Él manejaba muy bien el tiempo, los bloques de tiempo ¿verdad?

-JLG. El tiempo y el espacio; el cine. ¿Qué es el cine sino trozos de tiempo y espacio? La pausa bressoniana. Fíjate qué tiempos más distintos entre $U n$ condenado a muerte se ha escapado, Pickpocket y el tempo lírico de Al Azar, Baltasar, que es la única película que no tiene un tempo tan conciso, tan seco, es más rápida.

- JMV. Hablando de los hallazgos en arte. ¿Grabas a diario?

- JLG. No

- JMV. ¿Con qué frecuencia sacas la cámara y sales a grabar sin más?

- JLG. Cuando me he sometido a experiencias como en Unas fotos... o en Guest sí, me someto a la disciplina de ir con la cámara a todas partes. Pero después de estas experiencias es muy importante mantener una higiene mental. Esto ha terminado, se ha clausurado, salgo a pasear sin cámara. Es importante ver sin mediación de la cámara, es una forma de alienación terrible estar encuadrándolo todo. 
- JMV. Es decir no grabas por grabar, lo haces dentro de un proyecto

- JLG. Es sorprendente porque muchas veces has grabado algo sin saber porqué. Y sólo se revela mucho tiempo después, el motivo por el que has capturado una imagen. Tengo un proyecto, no sé si has oído hablar, que no se puede pasar de momento, que se llama Recuerdos de una mañana. Es una película de 40 minutos que la ha producido un festival de cine en Corea, que cada año produce un tríptico de tres partes y este año, produjo una pieza a JeanMarie Straub, otra a Claire Denis y otra a mí. ${ }^{8}$ La mía se llama Recuerdos de una mañana, y es un retazo de mi calle, pero a la sombra de un acontecimiento dramático, porque el vecino que vivía enfrente de mi casa, un violinista, todos los días ensayaba el violín en el balcón, se arrojó desnudo por la ventana y creó una conmoción. A mí me impresionó mucho que ese violinista acababa de traducir Las penas del joven Werther, de Goethe, es un libro para mí de cabecera, y es un libro que estuvo censurado en muchos países por apología del suicidio. Bueno, es un trabajo sobre esto, ese trabajo lo hice porque había hecho un plano del vecino tocando el violín en la misma ventana por la que se arrojó tiempo después. Yo no sabía que esa imagen... cuando volví de Guest porque estaba viajando cuando aconteció esto, tuve la necesidad de recuperar esa imagen.

- JMV. ¿Es premonitorio no?

- JLG. También Unas fotos en la ciudad de Sylvia no sabía por qué las hacía, tiempo después encontré el motivo, y dije, vale, era por eso. Está ese lado muy instintivo, y parece que a veces obedeces a este instinto. Es verdad que eso nos hace más parecidos a los artistas, porque antes de que existieran estas herramientas eso no podía ser así, no podías atender a tus intuiciones con esa sinceridad... debo tomar esa imagen.

- JMV. Con esa inmediatez

- JLG. Claro, tienes que estar muy seguro de las cosas para hacer imágenes en cine. Hay un gran presupuesto y un número de persona, no cabe ese grado de permeabilidad.

- JMV. ¿Vas a continuar por la línea iniciada en "Guest”? ¿crees que te ha abierto un camino o es un proyecto aislado?

- JLG. No lo sé, te diría que si no hubiese sido tan terrible la indiferencia absoluta con Guest, el que haya sido estrenada en la clandestinidad. Si esto hubiese sido de otra forma seguramente habría abierto un camino. Me hubiera gustado que se hubiese estrenado de una manera más normal y se hubiese podido visibilizar de otro modo.

- JMV. ¿Crees que tiene que ver el uso del blanco y negro? 
- JLG. No, no. Creo que fue debido verdaderamente a la indiferencia de la productora. Es muy importante crear una imagen de la película, y no lo hicieron, ni un anuncio del tamaño de un sello, un festival en el que no amortizaron la experiencia de ir a Venecia. Pensaron que era una película de festivales o de gente pobre, no lo sé. En construcción podría haber tenido la misma suerte que Guest. Yo estoy dolido con esto, y soy sensible también a esto, no soy impermeable ante la indiferencia.

- JMV. A como se recoge tu trabajo

- JLG. Sí. A veces he estado tentado de hacerlo, como los cineastas experimentales: yo a lo mío, y sin embargo sigo valorando el hecho de los estrenos los viernes, que me cuesta muchísimo, las entrevistas y formar parte del dispositivo mediático, pero creo que es un foco de resistencia que debo atender y temo también la actitud acomodaticia del que se aísla de todo esto...: "yo soy un artista y hago mi arte sin tener en cuenta nada más".

Si quiero concederme la posibilidad de hacer Unas fotos en la ciudad de Sylvia, lo hago con mis herramientas pero manteniendo un cierto diálogo con la sociedad. Esto me angustia, que el cine cuente tan poco ahora en la sociedad. Cuando yo descubrí el cine, era algo muy importante. Ahora es el fútbol, ahora las adolescentes en sus habitaciones no tienen carteles de actores ni de cantantes rock, sino de futbolistas, es el gran tótem sagrado de nuestra sociedad.

-JMV. ¿Crees que el cine tiene un sentido nostálgico de la vida? Es decir, la posibilidad de ver una película reiteradamente es responsabilidad del espectador, ¿pero de alguna forma el cineasta lo propicia?

-JLG. No creo que esté intrínsecamente en el cine. O sí, que diablos, en la medida en que rescata el tiempo que ha pasado, y es muy fácil que se desate la nostalgia. Sí, yo siempre tengo muy presente a Andrè Bazin, con su fórmula de "embalsamar el tiempo" (Bazin, 2001), el cine como el tiempo embalsamado. ${ }^{9}$ Como las manos con las que el hombre de la prehistoria dejaba marcas en su gruta. Es el mismo sentimiento, dejar una huella. Quizá esa impronta en el momento, pues no va instigado por la nostalgia en primera instancia, pero con el paso del tiempo lo que queda es eso, la huella de alguien que pasó por ahí. El cine tiene una belleza adicional sobre el video, en el hecho de que en la fotoquímica se abre realmente una huella de la luz. La intimidad con la realidad, es superior a la de los dígitos que se codifican y decodifican en las cámaras digitales. Resiste esa huella de luz del que estuvo enfrente de la cámara. Pero la nostalgia, desde luego no está en las máquinas, está en nosotros. 
Instructions for authors, subscriptions and further details:

http://brac.hipatiapress.com

\section{Génesis del Arte Minimalista: Aportación Mexicana}

\section{Pablo Estévez Kubli ${ }^{1}$}

1) Facultad de Artes y Diseño. Universidad Nacional Autónoma de México. México

Date of publication: June $3^{\text {rd }}, 2014$

Edition period: February 2014-June 2014

To cite this article: Estévez, P. (2014). Génesis del arte minimalista: Aportación mexicana. Barcelona, Research, Art, Creation, 2(2), 201-220. doi: 10.4471/brac.2014.09

To link this article: http://dx.doi.org/10.4471/brac.2014.09

\section{PLEASE SCROLL DOWN FOR ARTICLE}

The terms and conditions of use, except where otherwise noted, are related to the Open Journal System and to Creative Commons Attribution License (CCBY). The indication must be expressly stated when necessary. 


\title{
Minimal Art Genesis: Mexican Contribution
}

Pablo Estévez Kubli

National Autonomous University of Mexico

(Received: 20 January 2014; Accepted: 30 April 2014; Published: 3 June 2014)

\begin{abstract}
The article addresses the minimalist proposals of Mathias Goeritz and Luis Barragán from 1953, the Mexicans precursors of architectural and sculpture objects contributed to sustain the minimal art avant-garde. American artists of the sixties systematized in part the findings of Mexican architects in implementing minimum structures. The text proposes correspondences plastic root of Mexicans and Americans sculptors, using the method of comparative analysis. Furthermore, the Americans artist's sculptural theories and systems of construction to developed for the trend. Also, it is verified that the Mexican minimalist production incorporated formal compositional elements developed by the Americans. The text states that the Mexican minimalist work was consolidated in parallel with the Americans, with photographs and references substantiating examples of equivalent creations that enrich the avant-garde. Finally, we address the contemporary minimalist assemblage.
\end{abstract}

Keywords: Genesis, minimalism, correspondence, analysis, planimetric, assemblage, Mexican precursors, objects, parameters, contemporary, minimal art. 


\section{Génesis del Arte Minimalista: Aportación Mexicana}

Pablo Estévez Kubli

Universidad Nacional Autónoma de México

(Recibido: 20 Enero 2014; Aceptado: 30 Abril 2014; Publicado: 3 Junio 2014)

\section{Resumen}

El artículo aborda las propuestas minimalistas de Mathias Goeritz y Luis Barragán, a partir de 1953; los precursores mexicanos aportaron obra escultórica y arquitectónica para sustentar la vanguardia del minimal art. Los artistas estadounidenses de los años sesenta sistematizaron en parte los hallazgos de los arquitectos mexicanos en la ejecución de sus estructuras mínimas. El texto propone correspondencias plásticas de norteamericanos y mexicanos de raíz minimalista, utilizando el método de análisis comparativo. Por otro lado, los artistas estadunidenses desarrollaron teorías y sistemas de construcción para la tendencia. Así también, se verifica que la producción minimalista mexicana incorporó elementos formales compositivos desarrollados por los norteamericanos. En el texto se afirma que la obra minimalista mexicana se consolidó de forma paralela a la norteamericana, ejemplificándose con fotografías y referencias probatorias de creaciones equivalentes que enriquecen la vanguardia. Por último, se plantea la vigencia del ensamblaje minimalista contemporáneo.

Palabras clave: Génesis, minimalismo, correspondencia, planimétrico, análisis, ensamblaje, precursores mexicanos, objetos, parámetros, contemporaneidad, minimal art. 
1 origen de la vanguardia denominada minimal art corresponde a una cadena de acontecimientos y acciones que condujeron a un resultado concreto, incidiendo con propuestas plásticas en el siglo pasado. En tal sentido, Barbara Rose en su artículo $A B C A r t^{1}$ esgrimió que "la génesis del minimal como una reacción contra la subjetividad y los excesos del expresionismo abstracto" (Guasch, 2009, p. 158). El objetivo del artículo consiste en presentar concatenaciones de hechos artísticos que labraron el minimalismo en ambos países. Los inicios de la tendencia de la estructura mínima surgen en 1953 en México, con edificaciones arquitectónicas y esculturas urbanas de Mathias Goeritz y Luis Barragán. La literatura del minimalismo carece de referencias contundentes de nuestros artistas nacionales que provocaron el minimalismo. Encontramos que en la mayoría de los libros, ensayos y artículos sobre el minimal art se refieren a la aportación norteamericana como arranque de la vanguardia sin incorporar a la discusión la obra de Barragán y Goeritz. Por otro lado, consideramos que la obra escultórica minimalista realizada en México contiene diversas influencias formales, correspondencias compositivas y referencias conceptuales de la metodología estadounidense de los años sesenta del siglo pasado.

Sin embargo, los productores nacionales en la década de los setenta realizaron esculturas con una epidermis geométrica mínima, con formas cerradas y con la encomienda de emplazarlas en espacios públicos. Así también, los escultores nacionales en paralelo desarrollaron el concepto de la planimetría consistente en la aplicación de laminados metálicos con intercalación de vacíos; siguiendo de manera parcial las teorías de los minimalistas norteamericanos. Por otro lado, la literatura nos señala que Richard Wollheim en 1965 acuño el término "arte minimalista" (Schneckenburger, Ruhrberg, Frickey y Honnef, 2001, p. 524).

El minimal art consagra las estructuras de fachada industrial sustentadas en figuras geométricas, sistema modular, secuencia de partes, materiales laminados en emplazamientos en galerías, museos y espacios públicos. La investigación confirma similitudes, contrastes y correspondencias como la aplicación de sistemas industriales con materiales de la modernidad maquinista $\mathrm{y}$, sobre todo, la propuesta de formas abstractas-geométricas, composiciones formales y actitudes conceptuales de los escultores en su contexto. Así también, los minimalistas norteamericanos como Donald Judd y Robert Morris desarrollaron textos críticos que fundamentan la tendencia. 
Consideramos que en México los escultores de la década de los setenta construyeron las bases artísticas para que surgieran estructuras locales, asimilando los principios del minimal art. La aplicación inicial de la tendencia dificultaba establecer un orden minimalista en el quehacer de los escultores nacionales, ya que interpretaron con su lenguaje los parámetros vanguardistas conforme a conceptos y temáticas personales. Así también, utilizaron materiales industriales como laminados en metal, plástico y madera; construyendo estructuras con el sistema de maquila en talleres especializados al igual que sus colegas norteamericanos.

La incorporación del minimalismo emerge de manera amplia en la década de los setenta. El auge se inclina al final del siglo, con esculturas monumentales como La Puerta de Monterrey (1985) y Cabeza de caballo (1992), ambas del escultor Sebastián. Consolidamos la tendencia en los años noventa con varios escultores como Jesús Mayagoitia y Manuel Felguérez con propuestas de obra pública geométrica. En la Ciudad de México se construyeron la mayoría de las obras emblemáticas, marcando la diferencia entre lo escultórico tradicional y las piezas de arte minimalista en el país. El surgimiento de la tendencia con esculturas de bloque sellado generó un desconcierto entre la comunidad artística mexicana, al sustituir la tradición del desbaste, talla y modelado con láminas soldadas en estructuras mínimas. En tal sentido, constatamos que la línea de investigación nacional corresponde a influencias de objetos minimalistas de los años sesenta y sobre todo, por el antecedente de las obras de Goeritz y Barragán. En tal sentido, la aplicación de los parámetros minimalistas en nuestro país en la obra pública geométrica, refrendó en su momento la entrada a la modernidad escultórica (1985-1992) $\mathrm{y}$, además ampliamos el género con obra posminimalista en el presente siglo.

Así también, es necesario divulgar la aportación mexicana de tendencia minimalista fundamentada en autores relevantes que aludan a la génesis nacional. Además, analizaremos las propuestas estadounidenses y mexicanas con referencias plásticas para determinar la vinculación entre escultores de ambos países. El objetivo del artículo es evidenciar similitudes e influencias del minimal art entre productores y proponer un contenido formal para su entendimiento y valoración, a partir de las obras de los artistas nacionales. Proponemos analizar estructuras formales minimalistas a partir de 1953 en México y desarrollos posteriores. Los productores incorporaron conceptos plásticos de los norteamericanos determinando un parangón entre ambas estructuras objetuales. Por último, pretendemos asentar la vigencia del minimalismo local en el arte globalizado con ensamblajes escultóricos. 
Por otro lado, es necesario correlacionar el ensamblaje mexicano como aportación al minimalismo, ya que contiene estructura mínima por su fragmentación de partes industriales unificadas. Además, el neoensamblaje corresponde a "la acción o efecto de unir: ideas, objetos industrialescotidianos, conceptos, materiales, técnicas, medios alternativos que unifiquen en un todo la forma ensamblada" (Estévez, 2012, p. 60). El ensamblaje minimalista es construido por planos, prismas geométricos y en ocasiones con formas orgánicas parcialmente ajustadas a una forma sensible planimétrica. Así también, consideramos al minimal art como fundamento de lo escultórico mexicano al sistematizar la aportación del ensamblaje. El reduccionismo de la tendencia marca una etapa compositiva del productor, con objetos de epidermis mínima y reduce la expresión de forma. El ensamblaje conformado por fragmentos yuxtapuestos e híbridos se forja con implementos industriales como láminas, varillas, soldadura y uniones extremas con otros componentes. Ejemplificamos lo anterior con los ensamblajes de equilibrio de placas de acero realizadas por Richard Serra (San Francisco, 1939), en la obra The Matter of Time (1994-2005) ubicada en el Museo Guggenheim de Bilbao.

En defensa de la génesis del minimal art y su evolución en la producción escultórica local, confirmamos el desarrollo paralelo entre los escultores de ambos países. Las propuestas mexicanas de 1953-1958 son obras públicas como el Museo Experimental El eco y Las Torres de ciudad Satélite, que dieron la pauta para el desarrollo de la vanguardia por los precursores mexicanos. En tal virtud, Goeritz "seems to have anticipated certain ideas of the minimal artists" 2 (Battcock "et al", 1995, p. 19). Además, las obras emblemáticas de carácter minimalista aportaron al espectador la incursión física y libre a los objetos urbanos.

En México necesitamos confeccionar literatura especializada que abone al minimalismo mexicano, en especial su origen escultórico. El auge de la propuesta vanguardista norteamericana de los años sesenta contribuyó a crear un paralelismo en la producción mexicana. Así también, al vincular correspondencias plásticas en la construcción del objeto local a partir de los norteamericanos, contamos con evidencia de estructuras cercanas a la tendencia. Por último, el espectador de obra pública con formato geométrico verificará la cercanía formal-compositiva con el minimal art globalizado. En tal sentido, el veedor participa en las exposiciones de objetos mínimos en nuestros museos y galerías. Por lo que, el objetivo principal en el artículo consiste en dejar constancia de la aportación mexicana en la configuración del minimal art. Además, verificaremos los paralelismos de la producción 
escultórica entre estadounidenses y mexicanos de los años setenta a la fecha. Y por último, demostraremos la vigencia del ensamblaje minimalista en el arte contemporáneo.

\section{Aportación mexicana al minimalismo}

La observación que hace Gregory Battcock, en su libro Minimal Art a Critical Anthology (1968-1995) plantea que la obra de Mathias Goertiz (Danzing, (1915-ciudad de México, 1999), es cercana a las estructuras planimétricas geométricas de la tendencia minimalista. La edificación precursora corresponde al Museo Experimental El eco (1953) considerado la primera obra arquitectónica de carácter minimalista y, además contaba en su interior con la escultura La Serpiente de El eco (1953) forjada con planos laminados que consagra un volumen cerrado a partir de la forma y sistema se sujeción. En tal virtud, la correspondencia escultórica mexicana en el minimalismo es La Serpiente de El eco, que "constituyó toda una innovación en la escultura de la época, por sus formas acentuadamente lineales y fue predecesora del minimal art" (Moyssén, Rodríguez, Acha, Manrique y Del Conde, 1977, p. 70). La obra minimalista de Goeritz y Barragán la apreciamos en su dimensión vanguardista en la Ciudad de México, para abonar sobre nuestro argumento, nos dice Battocock que Goeritz:

...had designed an experimental structure in México City called El eco. The walls and other architectural components of the building were conceived in conjunction with large, Minimal sculptural pieces [La Serpiente de El eco (1953)] that all but took over the interiors [...] In El eco he explored successfully the problem of architectural enclosure (space) and the relationship of Minimal sculpture to the limitations of negative space -the floor, walls, and ceilings. ${ }^{3}$ (1995, p. 19).

Así también, Mathias Goeritz y Luis Barragán, construyeron el conjunto escultórico urbano denominado Las Torres de ciudad Satélite (1957-1958) edificado con prismas triangulares de 37 a 57 metros de altura con cinco módulos de cemento coloreado. La obra pública constituyó un señalamiento urbano para los suburbios de la Ciudad de México y los espectadores la consideran una obra emblemática. Otro antecedente de la génesis del minimal 
art, lo esgrime Víctor Pérez Escolano en su artículo Escalas del minimalismo. Arquitectura y escultura, señala que Luis Barragán es "citado como antecedente minimalista en razón a su elementarismo de matriz popular" (Pérez, "et al." 2003, p. 278).

El siguiente paso minimalista de trascendencia en la obra pública en la Ciudad de México, constituye el Espacio Escultórico (1979) erigida en el campus de la UNAM. La obra monumental de características minimalistas, es construida con 64 módulos poliédricos con base rectangular confeccionados de concreto armado, los objetos de repetición se encuentra alrededor de un cilindro de cemento y piedra de 120 metros de diámetro. La distribución de cada modulo tiene una constante de espacios y volúmenes con libertad de movimiento para el espectador entre cada uno de los prismas.

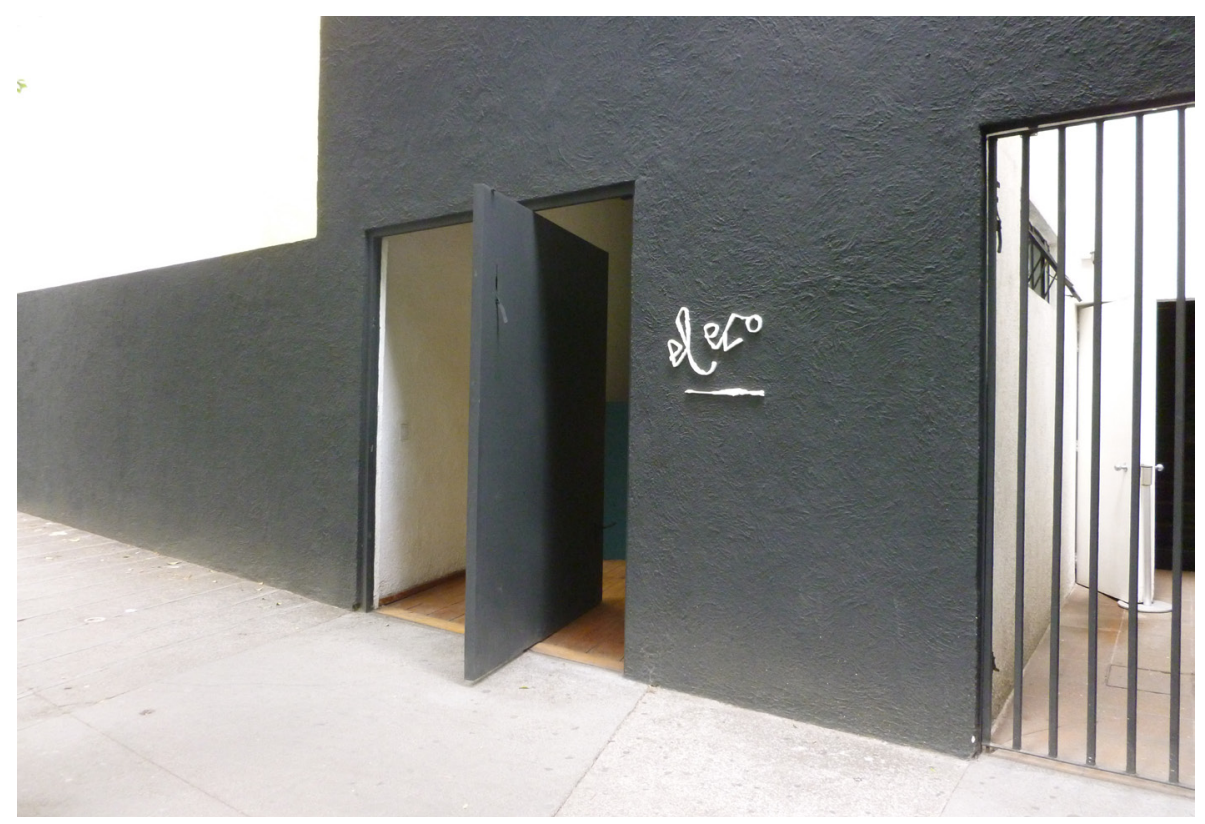

Figura 1. El Museo Experimental El eco (1953), Ciudad de México. Fuente: foto de Pablo Estévez Kubli. (C) 

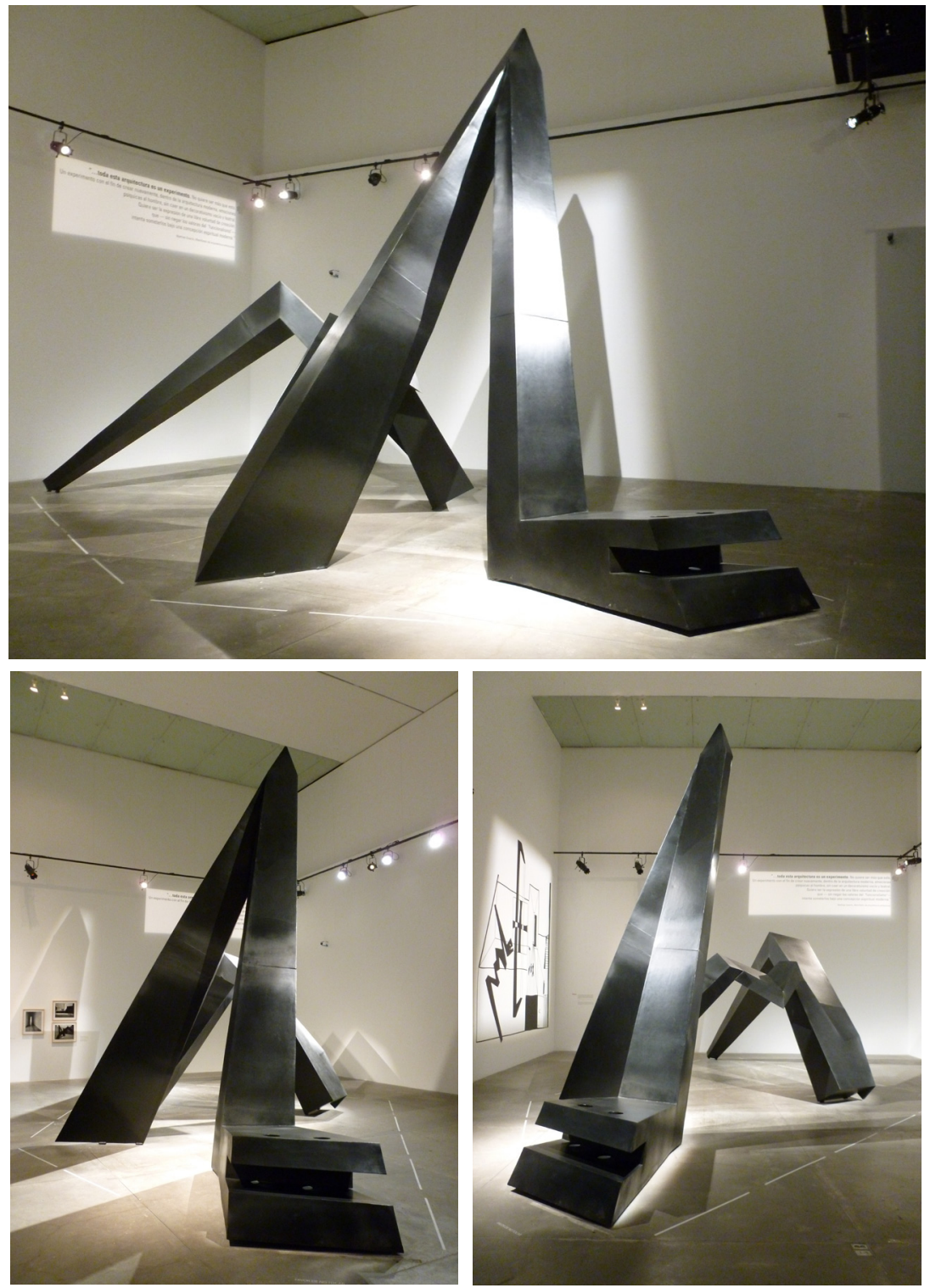

Figuras 2,3,4. La Serpiente de El eco (1953) en la Exposición Desafío a la Estabilidad Procesos Artísticos en México 1952-1967 en el MUAC-UNAM (2014), Ciudad de México. Fuente: foto de Pablo Estévez Kubli. (C) 
Por todo lo anterior, podemos asegurar que el minimalismo nace en México en los años cincuenta con obras trascendentes en la escultura y arquitectura. En Nueva York y en Los Ángeles, California se inicia el minimal art con estructuras geométricas, con procesos industriales de la modernidad y sobre todo con teorías elaboradas por los artistas estadunidenses que sostienen la tendencia. Los productores del minimal art son Robert Morris, Donald Judd, Sol LeWitte, Carl Andre, Richard Serra, Tom Doyle, David Smith y Eva Hesse, entre otros y del lado mexicano contamos con Hersúa, Jesús Mayagoitia, Manuel Felguérez, Sebastián, Gunther Gerszo, Ernesto Hume, Salvador Manzano, Ernesto Álvarez, Pablo Kubli, Ernesto Paulsen, Yvonne Domenge, Francisco Moyao, Xawery Wolski y Thomas Glassford, entre otros.

\section{Argumentación de estructuras minimalistas}

Consideramos dos argumentos que nos condujeron a escribir este artículo para presentar los hallazgos del lenguaje escultórico de artistas mexicanos. El primer argumento corresponde a la obra La Serpiente de El eco (1953) de Goeritz, construida con módulos laminados y remachados, desarrollando la planimetría volumétrica. Las correspondencias de la vanguardia minimalista de estructuras selladas como la obra citada, generaron respuestas directas a prácticas artísticas de autores como Donald Judd, Tony Smith, Sebastián y Jesús Mayagoitia, toda vez, que unificaron criterios plásticos al realizar esculturas geometrizadas de volumen cerrado.

Como segundo argumento, consideramos que la escultura mexicana de mediados del siglo veinte conserva resonancias formales, que aducen al factor espacio, planimetría y temática contextual. La obra minimalista local pertenece a dos variantes; por un lado, estructuras metálicas volumétricas selladas y por la otra, obra planimétrica con vacíos intercalados entre sus partes. El factor planista geométrico de la obra tridimensional (1953-1958) procuró nuestro devenir en el arte actual. Además, verificamos que la aplicación de laminados de diversos materiales provoca un desarrollo pleno en la producción escultórica en ambos países. Por lo que, consideramos que los dos componentes centrales en la ejecución de la obra contemporánea es la planimetría integrada a parámetros minimalistas. 


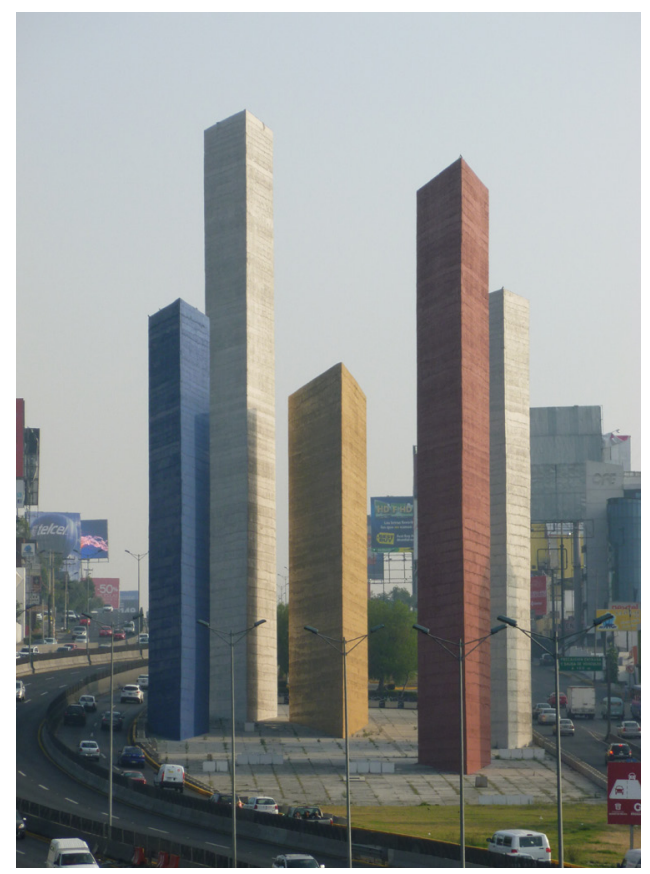

Figura 5. Las Torres de ciudad Satélite (1957-1958) Estado de México. Fuente: foto de Pablo Estévez Kubli. (C)

Así también, el espectador analiza la forma de estructura minimalista descubriendo correspondencias formales, conceptuales y técnicas. Los objetos de la tendencia con la aplicación de insumos de la modernidad maquinista demuestran las equivalencias plásticas entre la producción de nuestros escultores y los estadounidenses. Al analizar las referencias mexicanas del arte minimalista enriquecemos nuestro entendimiento de lo escultórico del minimal. Y nos preguntamos si es pertinente establecer correspondencias en el proceso creativo de los artistas radicados en México con otros fuera del país. En el presente siglo es innecesario cuestionarnos tal circunstancia, debemos aceptar la globalización del arte como un sistema de mutua interconexión. En tal sentido, es procedente que los artistas conserven factores de la tendencia y tengan referencias recíprocas en la producción de objetos de epidermis minimalista. Al demostrar los equivalentes plásticos entre objetos de una misma época, certificamos las influencias directas, parciales o adoptadas por los escultores mexicanos en el desarrollo del minimal art. 


\section{Características del minimalismo en la construcción del objeto}

La fuente sustancial del minimal art corresponde al material industrial consistente en laminados en metal, plástico, madera y aplicaciones tecnológicas en talleres metal-mecánicos. La industria pesada con implementos maquinistas abrió sus fábricas para forjar obras proyectadas por los minimalistas. Los artistas de la tendencia desarrollaron su forma de trabajo en base a la concreción de modelos, bocetos y maquetas a escala. Las obras se realizaron con diversas herramientas del área metal mecánica en procesos de maquinado y forja de laminados. La unión de sus partes fragmentadas de cada objeto derivó del uso intensivo de procesos de soladura, atornillado o remachado, siempre en busca de sistemas para sujetar los fragmentos de la obra. El auge del minimalismo conlleva a una epidermis geométrica volumétrica sellada en productores como Robert Morris, Larry Bell, Ronald Bladen, Tony Smith, Anne Truitt, Judy Chicago, Sol LeWitt, Hersúa, Sebastián y Jesús Mayagoitia.

Otro esquema compositivo en el posminimalismo se genera con planos sueltos con espacios intercalados sin pretender un volumen cerrado. En tal sentido, es conveniente distinguir entre los productores que realizaban estructuras totalmente selladas por sus lados -prismas geométricos- y los artistas que elaboran obras con planos sueltos dejando que intervenga el factor espacio entre sus partes. Los autores planistas crean espacios entre sus partes fragmentadas como Donald Judd, Carl Andre, Eva Hesse, Richard Serra, John McCracken, Manuel Felguérez y Pablo Kubli, entre otros. Los obreros metalúrgicos en general interpretan las proyecciones de los minimalistas creando la obra final con indicaciones precisas en su desarrollo, ya que "suele estar compuesta de formas geométricas únicas o repetidas. Producidas industrialmente o construidas por obreros cualificados siguiendo, las instrucciones del artista" (Meyer, 2011, p. 15).

La característica estadounidense corresponde a la visión conceptual que desarrollaron los artistas minimalistas al proponer eliminar las emociones del espectador sobre sus estructuras, Meyer nos dice que "erradican todo vestigio de emoción o de decisión intuitiva" (2011, p. 15). El esquema anterior es inexacto, ya que emerge algún tipo de sentimiento del veedor sobre la pieza. El proceso creativo que desarrollaron los minimalistas contenía la encomienda de forjar esculturas sin provocar gran emoción, lo que proponían era un cambio radical de la escultura previa a la tendencia y por lo tanto, evitar la apreciación del artefacto de manera tradicional. El cambio de paradigma lo 
describe Edward F. Fry en su artículo Sculpture of the Sixties ${ }^{4}$.

...el arte minimalista era demasiado extremo para encontrar su lugar en la historia del arte, ya que se trataba de una tentativa deliberada para escapar a los estilos anteriores al siglo XX y acabar con los métodos de composición que estaban en la base del arte occidental. (Guasch, 2009, p. 159).

En tal situación, entran a la discusión los factores formales, materiales y emocionales del espectador que provoca el objeto-escultura posminimalista contemporáneo. Otra característica del minimalismo es su estructura corpórea que se adquiere al utilizar sistemas industriales sin aparente emoción por sus laminados, estructura y sistema de conexión mecánica. El objeto minimalista es por esencia un cuerpo mínimo al ser conformado con pocos fragmentos híbridos o yuxtapuestos en su composición. Las estructuras se conciben libres de ataduras $\mathrm{u}$ oropeles en su forma, ya que se conforman con planos lisos y que provocan esquemas de reducción de forma, en tal correspondencia "el arte minimalista utilizó los objetos de producción industrial para lograr una reducción de tipo formalista" (Meyer, 2011, p. 18).

Además, el factor espacio se intercala entre las partes del objeto, es sin duda la característica principal del arte minimalista planimétrico, ya que genera vacíos interiores para establecer la forma definitiva. El factor espacio es acompañado conforme al tiempo, desplazamiento de partes y recorrido visual. El veedor para encontrar la forma definitiva se desplaza al rededor del objeto y logra observar el contenido de la obra en tiempo-espacio. En las estructuras planimétricas minimalistas el factor espacio juega de manera preponderante, ya que los vacíos son volúmenes virtuales que acompañan la estructura en su forma definitiva.

Otros elementos escultóricos minimalistas corresponden a la producción en serie, aplicación del sistema modular en repetición, progresión y la toma de decisión constructiva de volumetría cerrada o abierta por planos laminados; ambas acciones generan formas de carácter reduccionista. En un primer análisis de objetos de ambos países, verificamos apariencias de igualdad en el uso indistinto de los factores compositivos señalados para la construcción del objeto. En tal sentido, el primer objetivo de análisis atañe al sistema de agrupación de módulos construidos por volúmenes planimétricos, líneas engarzadas y conjuntos estructurales como las instalaciones de Robert Morris. 
Los ensamblajes minimalistas contienen las características del assemblage histórico, desde apropiaciones, reciclamiento, paráfrasis, materiales neutros hasta el uso indiscriminado de los parámetros del posminimalismo. La integración en la estructura por objetos encontrados, materiales de desecho, procesos industriales y fragmentos híbridos sustentan la forma física del ensamblado. Los escultores aplican la planimetría en sus assemblage y realizan estructuras compositivas de superficie-relieve, exentas y conjuntos que reflejan un lenguaje personal en la elaboración de cada pieza. Los productores mexicanos y estadunidenses comparten ciertos sistemas compositivos que se generan a partir del factor espacio-tiempo, formato liso, estructuras sin aparente emoción y la aplicación de sistemas industriales en la construcción del objeto por talleres especializados.

El material sustantivo para probar los alcances de la producción minimalista entre escultores norteamericanos y mexicanos es el análisis de estructuras concretas. El contraste, análisis y correspondencias se fincan en el uso de elementos formales en la elaboración del objeto de la tendencia. Ejemplificamos lo anterior con las cajas de pared abiertas de Donald Judd de su obra Untitled (1989) y la caja de zapatos de Gabriel Orozco en Empty Shoebox (1993), la primera es de aluminio con plexiglás y la segunda de cartón, pero cada escultor concibe su concepto sobre el espacio abierto de magnitud diferente. Otra vinculación corresponde a las estructuras de los prismas sellados de Tony Smith y su contraste con las esculturas de Sebastián, Jesús Mayagoitia y Hersúa. La diferencia radica en las actitudes de los escultores norteamericanos, ya que escribieron textos teóricos que sustentan la tendencia como en Specific Object (1965) de Donald Judd y, los de Robert Morris Notes on Sculpture (1966) y Anti-Form (1968); los ensayos nos proporcionan lineamientos formales del minimal art. La trascendencia de la postura norteamericana radica en proponer objetos anti-arte y por el lado mexicano, los productores asumieron sus objetos como escultóricos per se.

El estudio comparativo de objetos-estructuras analizados bajo premisas iguales entre obras plásticas de ambos países, nos da pauta para observar el paralelismo entre productores. Al analizar piezas de los escultores observamos características similares, materiales industriales igualitarios, composiciones rígidas geometrizadas y variaciones en la proporción del anti-arte como los norteamericanos o consagrar su esfuerzo formal escultórico en obras públicas como lo ejercen los mexicanos.

El resultado inicial del artículo versa sobre los hallazgos del minimalismo a nivel global, que corresponde a la arquitectura iniciática del Museo 
Experimental El eco, y a la escultura La Serpiente de El eco emplazada en el interior del Museo, ambas de 1953. Así también, la obra pública Las Torres de ciudad Satélite (1957-1958), construida por Luis Barragán y Mathias Goeritz; son consideradas las tres obras precursoras directas del minimal art. La evidencia en fotografías que se acompañan al cuerpo del ensayo, adquieren relevancia probatoria, además en la literatura del minimalismo se asienta en forma indirecta la hazaña mexicana. En tal sentido, vinculamos el conocimiento sobre las primeras obras públicas minimalistas (1953-1958) que se edificaron en espacios públicos en la Ciudad de México. En cambio la tendencia norteamericana surge de manera preponderante en la década de los sesenta en Nueva York y en Los Ángeles, California.

Iniciamos la discusión con el análisis de las estructuras tipo Cajas (1989) de Donald Judd al contrastarlas con la caja abierta Empty Shoebox (1993) de Gabriel Orozco. Evidenciamos que son objetos con similitud formal. La diferencia radica en su emplazamiento y materiales. Con relación a la obra mínima planimétrica sellada por sus lados como los prismas volumétricos de Robert Morris en Sin Título -L Beams- (1964-1967), al respecto Pérez nos dice que:

...los poliedros simples, como su Columna de 1961 o el conjunto de piezas acostadas, apoyadas o colgantes de la famosa instalación de la Green Gallery de Nueva York de 1964... [Morris generó] objetos cúbicos independientes o formas elementales de sección cuadrada [las propuestas de Morris consisten en un diálogo permanente entre estructuras, espacio, lugar y espectador]. (2003, pp. 271 y 272).

Además, Morris desarrolla la tipología site-specific que corresponde al lugar-espacio de emplazamiento de la estructura mínima, en tal sentido, Maria Hussakowska-Szyszko nos indica que Morris siguen en la actualidad investigando lugares determinados con connotaciones sociales y políticas que le proporcionen un análisis de ubicación significativa para implantar su instalación denominada Labyrinth-fragments (2010) y que:

The concept of site-specific art, developed by him in the 1960s and assuming a comprehensive analysis of the place, its history its social, cultural and political environment, which justifies and anchors the work...[así también Morris implementa] the expansion of Works 
that transcended their status as object, consequently undermining the understanding of a place through its history and spiritual hollowness. ${ }^{5}$ (Hussakowska-Szyszko, 2011, pp. 1-18).

En tal virtud, la realización y emplazamiento de prismas regulares laminados como obra minimalista, son objeto de diversas aplicaciones artísticas igualitarias en autores de ambos países. Las correspondencias formales de Robert Morris en su obra Sin Titulo-L-Beams- (1964-1967) ${ }^{6}$ y las estructuras prismáticas de Tony Smith Scale as Content (1967) y Free Ride (1962) ambas de formato geométrico cerrado; son cercanas a los prismas sellados que realiza Sebastián, Jesús Mayagoitia y Hersúa. Así también, otros elementos de análisis que utilizan los minimalistas norteamericanos y mexicanos radican en la aplicación de una sintética volumetría de forma y, utilización de módulos en repetición o progresión. Los norteamericanos además de forjar sus obras con producción en serie aducen a conceptos personales que reflejan en sus investigaciones teóricas. Los mexicanos consagran sus estructuras con pensamientos propios sin conceptos unitarios en la construcción del objeto, faltando rigor teórico en la estructuración del objeto posminimalista.

Además, las estructuras geométricas desarrolladas en ambos países contienen epidermis igualitaria a la vista del espectador, ya que son formas cerradas, planimétricas y con proporciones formales similares. Sin embargo, de lado mexicano las propuestas públicas de la tendencia son de gran calidad y emplazadas en todo el territorio nacional, conforme a "la estructura del ritmo geométrico, integración formal sobre bases reticulares y énfasis volumétricos [características principales para unificar a los escultores]" (Pérez, 2003, p. 285).

Por otro lado, con relación al factor compositivo silencio en la arquitectura minimalista, lo ejemplificamos con La Casa Luis Barragán (1948) edificada en la Ciudad de México. Las casas-habitación minimalistas de Luis Barragán generan "la fascinación de los escultores y arquitectos del emergente minimalismo por los modelos puristas de esa arquitectura [Mies van der Rohe y Hilberseimer] en la que domina el silencio" (Pérez, 2003, p. 289). Argumentamos que la simplicidad formal y mínima va de la mano con la composición de carácter intrincado, ya que con menos elementos en su construcción se genera una complejidad formal y ejecutiva en la fabricación del objeto minimalista de epidermis simplista pero de complejidad formal y conceptual. Consideramos distinguir entre lo mínimo y lo elemental, Pérez propone la tipología del minimal art de la siguiente forma, "un orden elemental cuya compleja construcción hace del minimalismo una categoría de fortuna contemporánea, con la que una larga mirada a la arquitectura moderna permite 
establecer el substrato histórico de uno de los capítulos más brillantes de la escultura del siglo XX" (2003, p. 289).

Así también, las fotografías de Hiroshi Sugimoto en su serie Seascapes -fotografías de la naturaleza- (1980-2003) nos demuestran la vigencia del minimalismo en otras disciplinas fuera de las estructuras escultóricas. Sugimoto artista japonés traduce la homogeneidad del paisaje retratado en estructuras mínimas bidimensionales con desplazamientos de tonos que van del negro intenso al blanco luminoso y con una variedad de grises por módulos horizontales que construyen la imagen. La utilización del horizonte bajo y alto denota la profundidad total que Sugimoto imprime en sus fotografías de plata-gelatina en un formato estandarizado. Además, la luz y las sombras de las atmósferas paisajistas de la naturaleza generan la estructura del objeto en sus diversas degradaciones de tonos, ya que son fotografías abstractas en las que existen diversas realidades conforme al sistema modular planista. Peter Krieger en su ensayo La estética del mar y otros minimalismos de Hiroshi Sugimoto, nos dice que:

...comunica el espíritu minimalista [...] En la serie se retratan los fenómenos esenciales y enigmáticos de luz, sombra, agua y atmósfera [...] Los paisajes marítimos infinitos, tan atractivos como aterrorizantes para el ser humano, sin duda exigen contemplación, evocan emociones y generan codificaciones. (2010, p. 137).

Otro referente comparativo entre mexicanos y norteamericanos, lo relacionamos a la serie fotográfica de secuencia marítima de Sugimoto con las pinturas de Mark Rothko (Lituania, 1903-Nueva York, 1970) que reflejan la inmensidad de las planicies, desiertos y montañas; provocando en el lienzo la unificación de tierra-cielo. En la obra Rojo, blanco y marrón de 1957 y en Sin titulo (mural de Seagram) de 1959, ambas de Rothko visualizamos el factor espacio en las composiciones que proyectan amplias zonas rectangulares de color. Los planos de pigmento son módulos que generan ritmos de color y forma mínima de carácter difuso. Rothko en sus años de formación en el estado de Oregón se acerca al minimalismo formal con franjas planistas que derivan del paisaje norteamericano de extensión colosal. Ante las obras de Sugimoto y Rothko, empequeñecemos ante el espacio-tiempo que representa, ya sea en fotografías de la naturaleza como en la serie Seascapes -mar-cieloo en las pinturas de Rothko con vacíos de tierra-cielo que corresponden a ambientes brumosos. 
Proponemos para ejemplificar el alcance del posminimalista la obra TorresDivisiones (1990-2013) de Pablo Kubli. Es un ensamblaje industrial realizado con dos elementos iguales en tamaño y proporción, enfrentados al factor espacio-tiempo entre estructuras y, transitable en su interior por el espectador. Los dos módulos de seriación igualitaria provocan vacíos entre las láminas de aluminio atornilladas. Las sombras y luces que emite la estructura metálica se transforman al ser intervenidas físicamente por el recorrido del espectador al sucumbir entre los módulos. La repetición de planos rectangulares genera armonía y solidez en su estructura de repetición, simultaneidad y se crean ritmos interiores entre cada módulo. Además, las líneas de las estructuras que conectan los módulos son tornillos amplios que unen los planos verticales igualitarios en forma y conexión, creando vacíos interiores entre cada fragmento. El veedor experimenta en su recorrido físico estructuras con características minimalistas.

Concluimos que la aportación mexicana es contundente, ya que los productores desarrollaron esculturas de formato minimalista proponiendo características formales para la tendencia. La constancia es determinante con obras urbanas a partir de los años cincuenta del siglo pasado como La Serpiente de El eco (1953), construida por laminados metálicos en formato geometrizante. Las correspondencias plásticas entre mexicanos y estadounidenses las visualizamos conforme a los prismas planimétricos de Tony Smit, Donald Judd y Robert Morris en contrapunto con esculturas de Sebastián, Jesús Mayagoitia y Hersúa. Además, confluye en la escena mexicana el ensamblaje escultórico con raíz minimalista de Pablo Kubli, ya que sus obras contienen yuxtaposición e hibridación de materiales que unifican fragmentos industriales en artefactos de corte minimalista. En tal sentido, demostramos con evidencia que la génesis del minimal art se produjo en la Ciudad de México con obra pública y, que la línea de investigación sigue vigente con propuestas contemporáneas. Además, necesitamos desarrollar literatura mexicana para analizar los procesos creativos de los escultores nacionales y su correlación con los estadounidenses. Las esculturas abordadas como evidencia conservan un juego espacial por movimiento, planos, líneas de conexión y sombras entre fragmentos con emplazamientos en lugares específicos. Por lo que, debemos construir la tipología del minimalismo mexicano en su devenir histórico contemporáneo. 


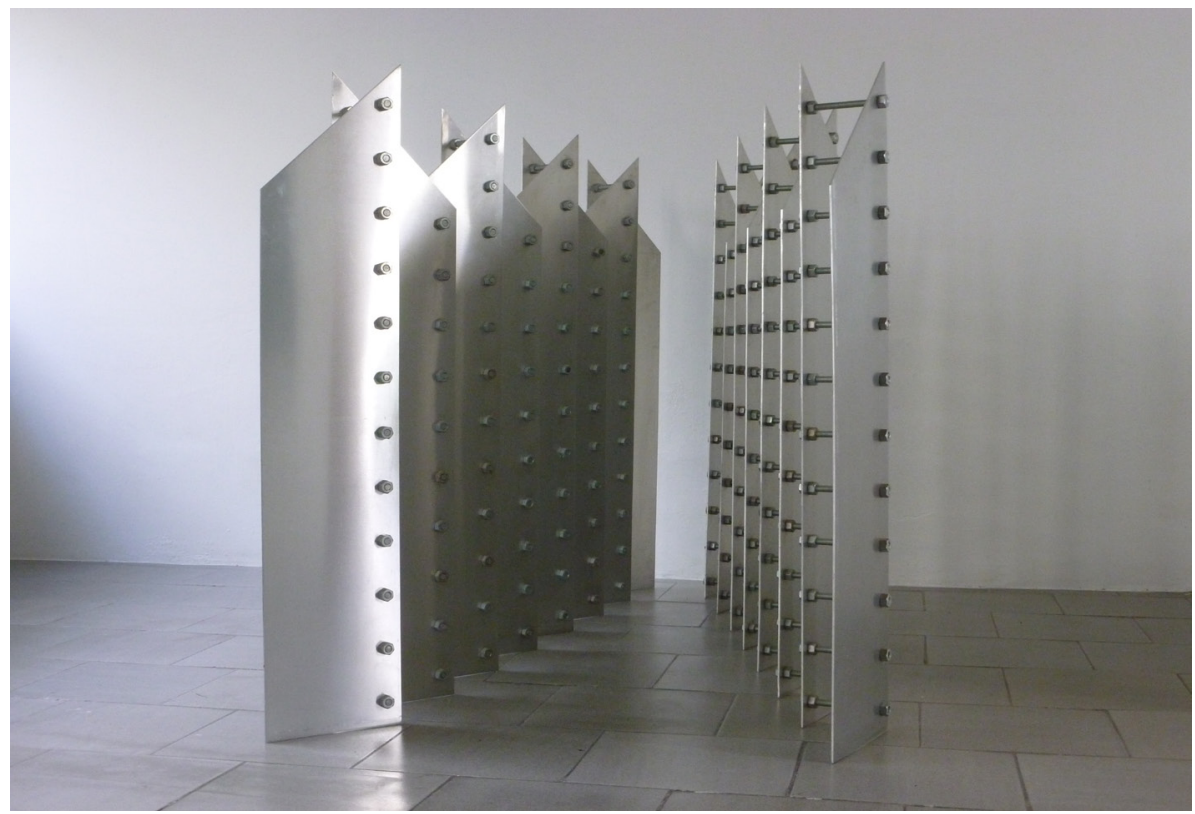

Figura 6. Pablo Kubli, Torres-Divisiones (1990-2013). Aluminio, tuercas y tornillos. 125 x 200 x $45 \mathrm{~cm}$ cada uno. Colección del autor. Fuente: foto de Pablo Estévez Kubli. (C)
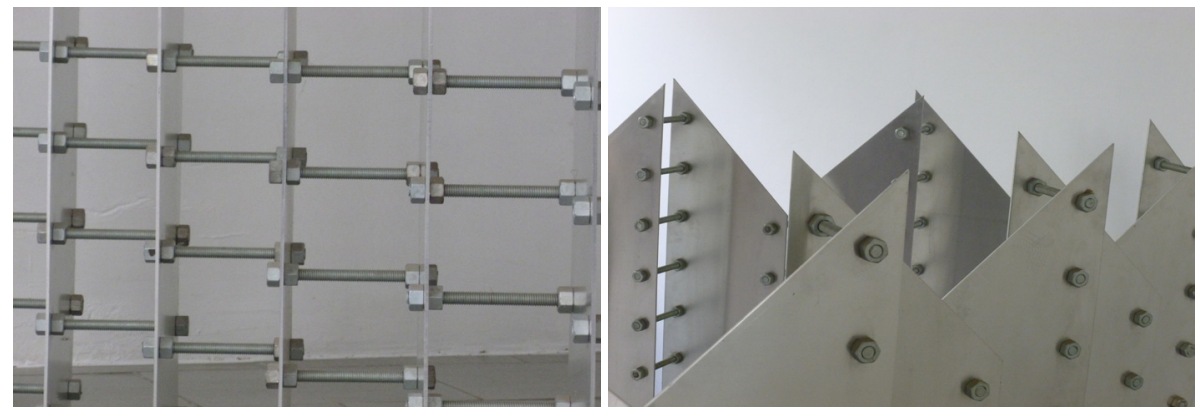

Figuras 7, 8. Pablo Kubli, Acercamiento de la obra Torres-Divisiones (1990-2013). Colección del autor. Fuente: foto de Pablo Estévez Kubli. (C) 


\section{Notas}

${ }^{1}$ Rose, B. (1965, octubre-noviembre). ABC Art. Art in America, 57-69.

${ }^{2}$ En tal virtud Goeritz parece haber anticipado ciertas ideas del minimalismo. [predijo los parámetros minimalistas como los factores de composición, materiales y sobre todo la aplicación del elemento espacio tanto en la escultura como en la arquitectura]. La traducción es nuestra.

${ }^{3}$ Mathias Goeritz había diseñado una estructura experimental en la Ciudad de México llamada Museo Experimental El eco. Las paredes y otros componentes arquitectónicos del edificio fueron concebidos en colaboración con grandes piezas escultóricas del Minimal [La Serpiente de El eco (1953)] todo se encontraba en los interiores [...] En El eco exploró con éxito el problema de la caja arquitectónica (espacio) y la relación de la escultura Minimal con limitaciones de espacio negativo, -el piso, las paredes y techos-. La traducción es nuestra. ${ }^{4}$ Fry, E. F. (1967, septiembre-octubre). Sculpture of the Sixties, Art in America, 28.

${ }^{5}$ El concepto de arte de sitio especifico, desarrollado por [Morris] en la década de 1960; supone un análisis exhaustivo del lugar, su historia, su entorno social, cultural y político, que justifica y ancla su obra [asi también desarrolla] la expansión de las obras que trascendieron su condición de objeto, por consiguiente, socava la comprensión de un lugar a través de su historia y su vacuidad espiritual. La traducción es nuestra.

${ }^{6}$ En la exposición Primary Structures: Younger American and British Sculptors en el Jewish Museum, New York (1966), Robert Morris presentó sus estructuras prismáticas minimalistas.

\section{Referencias}

Battcock, G., Wagner, Alloway, Bochner, Bourdon, Calas, Fried, Glaser, Goossen, Graham, Greenberg, Hutchinson, Lee, Lippard, Morris, Mussman, O'Doherty, Perreault, Rainer, Rose, Rosenberg, Sandler, Sharp, Varian, Wagstaff, Wollheim y Raysse, (1995). Minimal Art a Critical Anthology. Battcock (Ed.). Los Angeles California: University of California Press.

Estévez, P. J. (2012). El Ensamblaje Escultórico: análisis y tipologías objetuales del Arte Contemporáneo Mexicano. México: UNAM.

Guasch, A. M. (2009). El Arte del Siglo XX en sus Exposiciones. 1945-2007. España: Ediciones del Serbal.

Hussakowska-Szyszko, M., (2011). Labyrinth-fragments. Robert Morris and his installation for ms Lodz 2010. En RIHA Journal 0032 (15 November 2011), URN, URL, pp. 1-18. Recuperado 20 de Octubre de 2013, de: http://www.riha-journal.org/articles/2011/2011-oct-dec/hussakowskaszyszko-labyrinth-fragments 20.10.2013 
Krieger, P., Hernández, García, Dallal, Jácome, Argan, Volkow, Fernández,

Noelle y Hendrich (2010). La estética del mar y otros minimalismos de Hiroshi Sugimoto. México: Anales del Instituto de Investigaciones Estéticas, Número 96, UNAM, pp.133-144.

Moyssén, X., Rodríguez, Acha, Manrique y Del Conde (1977). El

Geometrismo Mexicano. México: UNAM, Instituto de Investigaciones Estéticas.

Meyer, J. (2011). Arte Minimalista. Londres: Phaidon Press Limited. Pérez Escolano, V., Rodríguez, LaHuerta, Bonzal, González, Llorens,

Castro, Hernández, Navarro, Marchán, De Barañano, Jiménez, Nieto y Arnaldo. (2003). Escalas del minimalismo. Arquitectura y escultura. En ¿Qué es la escultura moderna? Del objeto a la arquitectura. Martín de Argila (Ed.). Madrid: Fundación Cultural MAPFRE VIDA.

Schneckenburger, M., Ruhrberg, Frickey y Honnef (2001). Minimalistas norteamericanos y europeos. En Arte del Siglo XX. Walter I. (Ed.). Madrid: Taschen.

Pablo Estévez Kubli: Profesor en la FAD-UNAM. Universidad Nacional Autónoma de México, Facultad de Artes y Diseño.

Contact Address: Av. Constitución No 600, Col: La Concha, C.P. 16210 , Delegación Xochimilco, México Distrito Federal (Facultad de Artes y Diseño) México.

E-mail address: pablokubli@yahoo.com.mx 
Instructions for authors, subscriptions and further details:

http://brac.hipatiapress.com

\section{La página ideal de Sol LeWitt}

Eugènia Agustí ${ }^{1}$

1) Universidad de Barcelona. España

Date of publication: June $3^{\text {rd }}, 2014$

Edition period: February 2014-June 2014

To cite this article: Agustí, E. (2014). La página ideal de Sol LeWitt. Barcelona, Research, Art, Creation, 2(2), 221-247. doi: 10.4471/ brac.2014.10

To link this article: http://dx.doi.org/10.4471/brac.2014.10

\section{PLEASE SCROLL DOWN FOR ARTICLE}

The terms and conditions of use are related to the Open Journal System and to Creative Commons Attribution License (CC-BY). 


\title{
The ideal page of Sol LeWitt
}

Eugènia Agustí

University of Barcelona

(Received: 20 December 2013; Accepted: 28 April 2014; Published: 3 June 2014)

\begin{abstract}
"The ideal page" is an essay about Sol Le Witt's Wall Drawing \# 1126 Whirls and Twirls 1 (2004), which can be seen on the ceilings of the lecturer's hall of the Panizzi library in Reggio Emilia, Italy. With this exciting vision on our minds, this essay takes us on a journey through time, although we stay in the same place, in Italy, recovering the palette of the fresco paintings from the early Renaissance, applied in Giotto's and Piero della Francesca's figures, both of them Le Witt was devoted for.

The comparative reading which indeed occurs reversely, starts with murals, tainted in diluted colours, and continues with a revision of the minimal period, under the reference of Le Witt's understanding of the book Mallarmé as a multiple microcosm. From the word to the book, he regards it as a small universe reigned by a universal relationship: movement-space-time. This universe bares the key for Le Witt's interpretation of Mallarmé's stylistic composition, suggesting a regulated structure.
\end{abstract}

Keywords: Sol LeWitt, Mallarmé, colour, language, abstraction

2014 Hipatia Press

ISSN: 2014-8992

DOI: $10.4471 /$ brac. 2014.10

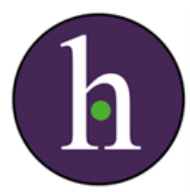




\section{La página ideal de Sol LeWitt}

Eugènia Agustí

Universidad de Barcelona

(Recibido: 20 Diciembre 2013; Aceptado: 28 Abril 2011; Publicado: 3 Junio 2014)

\section{Resumen}

"La página ideal" presenta un ensayo sobre la obra de Sol Lewitt, Wall Drawing \# 1126 Whirls and Twirls 1 (2004), ubicada en el techo de la Sala de Lectura de la Biblioteca Panizzi en Reggio Emilia, Italia. Bajo esta excitante visión que sobrevuela nuestras mentes, el artículo emprende un recorrido, trasladándonos en el tiempo sin movernos de Italia, para recuperar la paleta de los frescos del primer Renacimiento en las figuras de Giotto y Piero della Francesca, por quienes LeWitt manifiesta una gran devoción.

Este símil de lectura que emprenderemos se realiza a la inversa, y desde los murales teñidos con tintas diluidas, pasamos a revisar el período minimal a través de la lectura que LeWitt hace del libro en Mallarmé, entendido como un microcosmos múltiple. Desde la palabra plantea el libro como un pequeño universo regido por la relación universal: movimiento-espacio-tiempo. Este universo le aportará claves en relación a las ideas de una estructura reglamentada que LeWitt interpreta en la composición estilística de Mallarmé.

Palabras clave: Sol LeWitt, Mallarmé, color, lenguaje, abstracción 


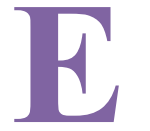

1 dibujo ha sido una práctica constante en Sol LeWitt (1928-2007) desde sus inicios, probablemente porque es al mismo tiempo lo más concreto y lo más abstracto. Es la primera definición gráfica, es donde se sintetizan más esfuerzos, es donde comienza el mínimo absoluto para que exista el universo, tal y como él proclama. Los dibujos se van sucediendo concatenadamente persiguiendo el sentido que marca la mente, devienen gestualidades del pensamiento. Un orden y una metodología conducen este comportamiento hacia un sentido, el sentido artístico.

\section{La página ideal}

Sobre una retícula compuesta por 32 rectángulos que corresponden a tres órdenes de medidas diferentes se ha insertado el centro de la figura ideada por Sol LeWitt. Una docena de grandes curvas perimetrales delimitan esta curiosa y compleja forma que a la vez contiene una cantidad importante de contracurvas interiores, intersecantes a los trazos concéntricos derivados del perímetro externo. Se trata de Wall Drawing \# 1126 Whirls and Twirls 1 (2004). Resulta ser la página ideal para una lectura sobre Sol LeWitt.

El complicadísimo proceso matemático contrasta con el sentido más vital y humorístico que solo los colores seleccionados permiten consentirle. Son seis los colores que LeWitt ha pautado para esta ocasión: rojo, amarillo, azul, naranja, verde y violeta. Colores acrílicos aplicados con rodillo. El resultado es el de una superficie de color completamente plana, con un enorme grado de interactividad. Los matices han desaparecido en el wall drawing que estamos describiendo: las superficies son homogéneas y uniformes, la forma se repliega sobre si misma para ofrecer exclusivamente los colores que la componen. Esta significación alternativa que los colores primarios, secundarios y complementarios le confieren, sustrae cierta trascendentalidad a la obra. Se hace patente un hecho diferencial en relación a como interpretar o intuir en etapas precedentes sus dibujos murales de las décadas de los años ochenta y principios de los noventa.

El techo de la Sala de Lectura de la Biblioteca Panizzi de Reggio Emilia (Italia), ideal para la proyección de esta forma aislada, recibe este único contenedor bidimensional. A diferencia de otras ocasiones no son múltiples elementos sin jerarquía o dispuestos según criterios de seriación los que conforman el dibujo, sino una figura plana exenta de fondo. En esta nueva 
manifestación morfológica estructurada con la máxima rigurosidad, la máxima sensibilidad y la máxima idealización del concepto a los cuáles nos tiene habituados, la influencia entre forma y color es recíproca. Interactúan alternativamente haciendo creíble que el desplazamiento visual pueda realizarse por debajo, por encima y entre las curvas solapadas. Corrobora la capacidad ilusoria del dibujo más allá de las posibilidades perceptivas reales.

Podría ser esta la forma que reivindicaba Donald Judd el año 1976 al decir: "La principal virtud de las formas geométricas es que, a diferencia del resto del arte, no son orgánicas. Una forma que no fuese geométrica ni orgánica sería un descubrimiento importantísimo" (Judd, 1991). La transformación discontinua que apreciamos si vamos siguiendo alguno de los recorridos que marca el dibujo aumenta con la intermitencia de los colores. Como en la cinta de Möbius, este objeto bidimensional ofrece una sola cara y no es orientable.

El grosor de las curvas se mantiene regular, pero no sucede así en la anchura de las casillas que va siendo variable durante todo el laberinto, dificultando el seguimiento visual de esta teselación orgánica. Si unimos la exuberancia cromática a la sensación de aceleración luminosa de esta suerte de meandros, nos sentimos acogidos bajo una especie de caos cosmogónico equivalente a la densidad que presentan ciertos fluidos de diferente viscosidad. En la disposición interna, la concatenación individual de las casillas, aparentemente infinitas y obsesivas nos dirige de una parte a otra; observamos una cadena donde las partes están vinculadas a un todo, no hay ninguna referencia, nada que indique donde empieza ni donde termina. Deducimos que si la seriación significa que todas las partes de la obra reciben el mismo trato siendo consideradas de igual importancia, estaríamos situados ante la recreación de la idea permanente de LeWitt: individualmente cada color fragmentado sería equiparable a un elemento de sus premisas de seriación. La importancia es su valor en el total del conjunto. Con la sucesión interna LeWitt puede superar la repetición de las unidades de color y pasar a una estrategia más prolífica.

Seguidamente, la particularidad destacable es la disposición de la coloración dentro de estas circunvoluciones. Una de las características esenciales del color es su inestabilidad y no todos los colores tienen el mismo grado de mutabilidad. Alteración inevitable asociada al transitar, al fluir, a la dinámica. Sinuosidad que nos transporta a una hiperactividad, programada mediante la diagramación de estos colores que nos conducen a seguir este itinerario de rodeos prefijado por los verdes, rojos, morados, amarillos, azules y naranjas. Asistimos a una actividad cinética de una sorprendente provocación por contraste simultáneo que nos deja estupefactos. Nuestro órgano de la visión 
no demuestra suficiente habilidad para adaptarse y cambiar los aspectos del color por la influencia de los colores fronterizos.

Ante la connotación orgánica de este indefinible circuito de curvas, se activa nuestra facultad evocativa bajo esta nebulosa luminosa y esclarecedora. Nos invita a la admiración, por medio de la que puede ser la acción más contemplativa de todas: mirar el cielo. ¿Qué mejor idea que una lectura del color sobrevolando nuestro pensamiento durante una sesión de estudio? Estímulo de la vitalidad cerebral a través del gesto matemático que conjuga azar y control.

Utilizando recursos de alta complejidad matemática — para hacernos una idea de la envergadura del proyecto, el cálculo matemático de preparación del dibujo mural en el espacio duró alrededor de tres semanas. Dibujarlo costó diez días, mientras que la aplicación del color implicó tres asistentes y nueve ayudantes, durante poco más de un mes - establece un puente de evasión, abre una vía hacia la imaginación. Sintonía entre concepto y arte. Idea y arte. La belleza de las ideas. No es la primera vez que LeWitt utiliza los colores acrílicos Lascaux, aplicados a razón de cuatro o seis manos hasta obtener la solidez requerida. Los colores ya estaban presentes en Continuous Forms (1987); en la serie Curves and Loops donde el valor caótico de las curvas se incrementa con la interactividad de la gama; en el Wall Drawing \#972. Forma isométrica contornos (2011), instalada en el Museo Irlandés de Arte Moderno de Dublin; en Splat (2001), ubicado en el centro de arte CaixaForum de Barcelona; en los Wall Drawings 1045, 1026 y 1047 Barras de color (2002), presentados en la fundación Pedro Barrié de la Maza en La Coruña (España) o en el Wall Drawing \# 1110 (2002) de la Hallmark Cards Inc. en Kansas City (USA).

En anteriores ciclos de su extensa obra, el despliegue mural nos situaba en otras condiciones de percepción, nos persuadía para una completa inmersión en su geometría del color. Ahora, estamos invitados a la contemplación. Los cambios de técnica, la escala, los elementos formales del dibujo mural han ido variando con el paso del tiempo, pero existe una continuidad desde 1968: "quería realizar una obra que fuese lo más bidimensional posible. Me pareció más natural trabajar directamente sobre la superficie de la pared que fabricar una construcción, trabajar en ella, para después colocarla en la pared" (LeWitt, 1970).

Si en el Trecento y el Quattrocento desvelar el misterio de la imaginería a los fieles era la misión, LeWitt escoge un sistema organizativo de similares características, incluso más pregnante y más enigmático, como es la figuración 
geométrica, despojada de su carga simbólica pero con todo el potencial experimental del dibujo proyectual para ensayar todo un ejercicio sobre el color que trasciende la propia geometría: la conciencia de pertenecer a la tradición de los siglos. La insistencia por contrastar otras realidades de color a lo largo de los años supone cerca de más de 1.100 dibujos murales en los que ratifica su filosofía llevándola a la práctica. Como respuesta al hecho que a cada pared le correspondería un dibujo, esta misma podría extenderse, a que a cada pared también le corresponderían unos colores determinados. En plural, porque cada ocasión, cada wall drawing es la demostración de la pluralidad del color. La confirmación, una vez más, que el color siempre "es" en relación a otros, y que somos capaces de nombrarlo, por comparación con su próximo.

Aunque en su propósito inicial buscaba un sistema de trabajo que le permitiese distanciarse tanto de la pintura como de la escultura, el desarrollo de los dibujos murales le lleva paulatinamente a inclinarse por efectos pictóricos, o por los dibujos de color, - como queramos nombrarlo-, bajo otras convenciones que ya ha procurado establecer y documentar. La calidad de estas paredes transpira bajo el color. Transpira el muro, transpira el edificio, transpira la cultura que impregna los lugares de destino. Sea una iglesia desacralizada convertida en un nuevo centro de arte, sea la galería de un museo, sea un encargo para una vivienda particular.

"No me preocupa tanto el efecto efímero de estos dibujos en la pared que desaparecerán bajo la capa del color original del lugar donde han sido emplazados, ni establecer relaciones de solidez ni temporalidad" expone LeWitt (LeWitt citado en Montolío, 1996). En este aspecto difiere del planteamiento de los italianos renacentistas: su pintura tenía que perdurar sobre las inclemencias de los siglos. Los frescos estaban pensados para su permanencia. Técnicas ancestrales de preparación del soporte que debía recibir imprimaciones previas a la acción del maestro artista y las fases sucesivas destinadas a sus colaboradores. El paso de los siglos ha jugado en contra de la conservación y el mantenimiento de estas maravillosas obras que en la envergadura de su proyección, evidencian su afán de permanencia.

En referencia a la estabilidad estaríamos de acuerdo con Montolío (1996) cuando comenta: "Algo nos sugiere que continua perdurando, pero esta sensación no viene dada por una duración material ni por una proyección hacia un futuro sin plazos, sino quizás por elementos como la posibilidad de avanzar infinitamente las series proyectadas o por la misma idea de perfección e inmutabilidad que atribuimos a la geometría. En Paragraphs escribía que su propuesta conceptual implicaba que "la idea se convierte en una máquina que 
produce arte" y "que el arte conceptual busca implicar la mente del espectador más que a su ojo o a sus emociones" (LeWitt, 1996, p. 50).

Queda bien claro que el Wall Drawing \# 1126 Whirls and Twirls 1 de la Sala de Lectura Panizzi no está exento ni de emociones ni de visualidad. A LeWitt le interesa la multiplicidad de las cosas, en especial la multiplicidad de las cosas que pueden generarse a partir de una idea simple. Podríamos aplicar la sentencia que el hábito sustrae a la repetición algo nuevo: la diferencia (Deleuze, 2002, p. 124). En esta dirección, a base de estipular un método serial encontramos una nueva aportación en la obra de LeWitt: el hecho diferencial. Y más aún, podemos añadir a esta diferencia otro aspecto: Sol LeWitt inaugura el concepto de "dibujo mural" distinguiendo su obra de la metodología pictórica. Esta separación sustrae a la pintura la magnitud de la tradición y hace diferencial su trabajo al decantarse por el dibujo.

La lectura sobre el color que podemos extraer de LeWitt es que el arte llega a alterar nuestra percepción modificando nuestra manera de entender las convenciones. LeWitt supera las normas de la pintura y establece que la percepción de ideas conduce a nuevas ideas; la predisposición a comprender de otras maneras el color nos lleva también a imaginar otros resultados para aspectos colorísticos en que dibujo y color no están separados, sino en continuidad. Cubos, prismas, poliedros, pirámides, ondulaciones y bucles, dejan de ordenarse según la idea común de serie, se transforman en los murales siendo parte de la propia obra, con igual importancia, pero ya no surgen de la misma idea básica, y por lo tanto, cada parte individualmente ya no es igual a otra.

\section{Viaje a Italia}

"Me gustaría que mis trabajos llegasen a cuanta más gente, mejor... También me gustaría crear una belleza universal... Me gustaría producir alguna cosa que no me avergonzara enseñar a Giotto”, confesaba Sol LeWitt a MillerKeller. (1994, p.112).

En el primer periodo se podía hablar de confrontación y aislamiento del espectador en relación a las obras. En Whirls and Twirls 1 (2004) la sensación es envolvente, estamos insertándonos en su espacialidad. El sentido de fresco en sus dibujos murales no obstante, obedece más a un análisis de dimensión. Esta ampliación se multiplica y abarca todos los sentidos. Al contemplarlos podemos hablar de sensaciones, emociones, atmosfera, también incluso 
de una reivindicación del color ante el dibujo, de un color como portador de contenidos, de un color que se distancia del carácter artificial de las coloraciones de Frank Stella, Donald Judd o Elsworth Kelly.

Color que, durante un amplio período, toma unas connotaciones naturalistas próximas a los frescos italianos del Trecento y del Quattrocento que tanto admira. "Piero le atrajo por su sentido del orden, al cuál sobreponía un sentido de la pasión y del ritual" dejaba constancia en una entrevista el año 1993 en la revista Art Monthly. Desde el momento en que se siente interesado por Giotto y Piero della Francesca no puede desvincularse de estas filiaciones con la historia del arte europeo. Su obra provoca una serie de replanteamientos entorno a preocupaciones tradicionales que tienen mucho que ver con las búsquedas de la pintura contemporánea. Sus largas estancias en Italia respiran en muchas de sus obras. En realidad no existe diferencia entre el LeWitt de los artículos conceptuales y el de los wall drawings; se trata de la misma actitud estética, la pintura continua siendo una "cosa mental", tal y como lo quería Leonardo da Vinci.

El uso del color en el Renacimiento disfrutó de un deleite que no volveremos a ver hasta el siglo XX, cuando los pintores harán del color el tema de su arte. Para este uso podemos distinguir las diversas interpretaciones que los artistas de ese momento otorgaron a aquel "renacer". Los artistas buscarán nuevas maneras de organizar la gama creciente de colores a su disposición. Por primera vez en la historia, los pigmentos ya no debían ofrecerse a la devoción de una deidad, se intentaba representar el mundo tal y como se ofrecía a los ojos.

Giotto di Bondonde (1267-1337), fundador de la escuela florentina de pintura, asentó los fundamentos innovadores de la futura representación pictórica en su tentativa de dar relieve a los objetos, representándolos de manera tridimensional, mediante luces y sombras creadas por una fuente específica de iluminación. Por primera vez los objetos y las personas representadas proyectaban sombras, superando la rigidez de las formas que caracterizaban el arte bizantino. Curiosamente esta aceptación durante la Edad Media se consideraba irrelevante. La pintura era una manera de narración sin palabras y alcanzando el mensaje se daban por satisfechos. No obstante, dicha categoría narrativa era primordial. Siendo el lugar, la pintura era también la ocasión suntuosa que no existiría si no fuese por su condición de noble o sagrada. El público disfrutaba de la neutralidad de los espacios que la acogían. La naturaleza del muro, en este sentido, atraerá también a LeWitt.

Giotto incorpora al espectador en la escena donde ocurre la acción, 
concentrando todo su interés en este punto, promueve su contemplación; a su vez convierte el tiempo en elemento pictórico, la imagen ya no es un símbolo de lo inmutable, más bien queda fijada en un momento pasajero del tiempo real. Este hecho tuvo repercusiones extraordinarias para los pintores traspasando las fronteras temporales para llegar a principios del siglo XX, cuando los cubistas recuperan su figura y la mirada hacia su pintura. La liberación de la composición medieval dio paso a una diversidad de formas y colores para interpretar. Además, el artista del Renacimiento adquirió la capacidad de colocar los objetos con precisión en el espacio. Estas características del lenguaje de Giotto no se escapan a LeWitt quien de manera casi reverencial nos explica como querría mostrar al artista en calidad de discípulo, su aportación a la creación artística, algo de una belleza que transcienda el tiempo, tal y como ha sucedido con las obras de Giotto.

En La capilla de los Scrovegni ya encontramos una idea de serie con ciertas analogías asociables a la obra de LeWitt. Ampliando ciertos matices de concepto, el punto de donde surge la noción secuencial no distaría demasiado. Las escenas de Giotto están configuradas de tal manera que, como pinturas adquieren un significado propio, y en conjunto transmiten el impulso necesario para la continuidad de la historia. La acción también se impulsa reproduciendo los mismos edificios en diferentes imágenes. La repetición de situaciones espaciales no solo transmite la idea de un flujo narrativo continuo, sino también, de manera especial, el lugar correspondiente a la acción. La clara definición del lugar hace que lo que sucede parezca muy natural. Mediante esta localización la acción obtiene una presencia directamente inteligible. Presencia que se mantiene con los personajes, sus encuentros y la expresión de sus sentimientos reproducidos de manera muy diversa.

El artista todavía no pinta los paisajes alejados ni los espacios interiores profundos que tan representativos serán del Renacimiento posterior. Aún así, sus edificaciones, templos y montañas no son simples alusiones. Son elementos que dan ritmo a la acción y el color es parte activa de esta rítmica que acompaña a la acción. De algún modo LeWitt recoge estas sensaciones elementales y primitivas que transmitirá a sus volúmenes estáticos: a medida que los representa reiteradamente, aún desarrollándolos con más complejidad, nos suministra las claves para identificarlos y comprenderlos. Gracias a las axonometrías y otros recursos de la perspectiva transforma sus objetos tridimensionales, que en sucesión — como en la narrativa de Giotto-, irán abriéndose bidimensionalmente en el espacio, desplegando el cúmulo de ideas contenidas destinadas a un inevitable placer sensorial. 
Si tal como hemos apuntado anteriormente, afirmaba que su valoración sobre la "idea conceptual" implica a la mente del espectador más que a su percepción o emociones, se podría relativizar su afirmación y constatar que es precisamente desde la emoción que nos transmite la visión de sus murales que estamos calificados para captar "su idea": qué les da vida, qué indagamos en su intervención mental. Discutir sobre el orden mental es una falacia, las interpretaciones son individuales más allá de lo que dicta el propio artista. La redución a la lógica o a resultados estrictamente formales no es explicable en un artista como Sol LeWitt que oculta connotaciones de envergadura más hedonista, que no solo reduce la experiencia de la contemplación del objeto artístico a una comprensión intelectual, a pesar de afirmar que una de las razones para que su obra sea geométrica tiene origen en el deseo de hacerla sencilla y simple.

El tratamiento del color es decisivo en su sistematización, como lo es también en la activación del sentido espacial de sus series. Ya bien sea en un despliegue extensible en la pared o en una sucesión de imágenes catalogada, qua vamos viendo hoja por hoja, de manera más próxima a la carta de color a través de impresiones sobre papel como la Serie de 100 cubos, originales en gouache que se muestran expuestos en una pared donde los cinco colores presentes en cada obra (los tres destinados a las tres caras visibles del cubo, más el color del perfil que los encuadra) interactúan entre ellos como las tinturas de la gama del Atlas de Chevreul, o compilados en un libro de artista de edición limitada de una excelencia cromática sin paragón. Las sensaciones son homónimas, las percepciones nada distantes.

El color en Giotto, bajo la influencia de Cimabue y los mosaicos florentinos, destaca por ser singularmente luminoso, basado en el inventario de las técnicas del "buon fresco" y el "secco fresco": blanco de cal, azurita, ocre amarillo, ocre rojo, tierra verde vienen a nuestros ojos como los azulados turquesas, verdes semi-claros, azules oscuros, delicados matices grises-azulados plateados, débiles tonalidades violáceas y rosadas, rosas amarillentos intensos... Observando de cerca la serie citada de LeWitt, y salvando las distancias técnicas del gouache, las coloraciones aplicadas beben de las que acabamos de citar. La posibilidad de observar estas obras en directo, y algunos de sus wall drawings ratifican esta debilidad por el color desde el conceptualismo.

Las pirámides desplegadas por Sol LeWitt toman una identidad diferente, pasan a ser una nueva forma independiente que ya no está vinculada al sistema serial. La complejidad de estas nuevas figuras es de una bellísima policromía. A partir de los colores directos usados en la impresión del papel y sus evoluciones 
en tintas aguadas, las coincidencias con la paleta italiana se hacen visibles, y admirándolas, podemos hablar de preciosismo. Los efectos de lavado dejan respirar los variados colores que se aplican en una misma área del muro; inicialmente se empieza con el color directo con bases de tintas aguadas que se van embelleciendo por las sucesivas aplicaciones de otras tintas. La mezcla del color se produce directamente sobre el muro y no durante una preparación previa. Se utiliza un sistema elaborado de aplicación con trapos de algodón en diversas fases, hasta que el color va subiendo consiguiéndose el tono programado, que recuerda al entintado con tarlatana de la lámina de metal en calcografía. La obra evoluciona paralela a la movilidad que nos muestran las últimas sucesiones de estructuras concatenadas que se van abriendo al ocupar la pared, asimismo las sucesivas incorporaciones de otros recursos dibujísticos conducen la evolución de su obra hacia la expresividad y la subjetividad.

LeWitt explica como se siente también seducido por el sentido del orden que se respira en la obra de Piero, por sus figuras poderosas y sublimes, enigmáticas y a la vez emblemas de su época. Entre sus muchas reflexiones sobre el arte, Piero della Francesca (1420-1492) dejó escrito que las formas son "hermanos en buena armonía en el salón ancestral del espacio" (della Francesca citado en Laskowski, 2000), y se hace patente que el artista del Renacimiento se servía de la composición geométrica para acentuar sus propósitos. Podemos ver que la construcción de sus obras se basa en formas geométricas puras y la composición se desarrolla a partir de cuerpos idealizados, tema sobre el que Piero escribió su tratado De corporibus regularibus. ¿Podría estar LeWitt haciendo un guiño a las nubes de Piero, con su "forma nube" del techo de la Biblioteca Panizzi?

Las nubes que aparecen en repetidas ocasiones en su obra, recuerdan por su forma la rotación de los cuerpos geométricos. Sol LeWitt utiliza recursos sencillos para insinuar movimientos similares. Los colores de Piero llevan a término exactamente la misma función de definición del espacio que sus formas. Constituyen un ejemplo de las diferentes tonalidades de un color, degradadas rítmicamente, estimulan al observador para fijarse en la distribución espacial. Esta característica se convirtió con el tiempo, en una de las peculiaridades estilísticas remarcables de Piero della Francesca. Resalta por una combinación singularmente armónica del compendio renacentista, donde el ocre, el púrpura azulado, el rojo, el rosa, el tierra verde y "verdigris", y el azul de ultramar son algunos de los tonos utilizados en la mixtura de sus armonías.

$\mathrm{Su}$ inventario formal y colorístico constituye uno de los momentos 
culminantes en la pintura del primer Renacimiento, por sus personajes bellísimos e imponentes, por su colorido y serenidad espiritual, sus creaciones continúan sorprendiendo por su modernidad. Consiguió conciliar los conocimientos científicos y artísticos de su época con la visión espiritual del mundo, ejerciendo de mediador entre el Gótico y el Renacimiento, entre la tradición y la modernidad.

Piero crea una rítmica contrastada de colores cálidos y fríos a través de las vestimentas de los dignatarios eclesiásticos. Asigna unas tonalidades frías o cálidas en función del estatus que los personajes representan en la escena de la pintura, por ejemplo, entre la corte eclesiástica y los ángeles; entre los cortesanos y los soldados. También traslada estas relaciones a las fisonomías de los personajes, que vemos aprovecha en diferentes ocasiones, siendo equiparables en su uso al manejo que hace de la geometría. Si nos centramos en la pintura El bautismo de Cristo (1440-60), podemos percibir que las formas básicas de la composición son un cuadrado que sobresale de un semicírculo, cuatro triángulos equiláteros y un pentágono. Los cuatro triángulos convergen en la figura de Jesús, las manos que ocupan el centro del triángulo superior, zona donde se centra la atención de nuestra mirada.

Muchas de sus obras no han llegado a nuestros días; solamente aquellas que han resistido el paso de los siglos. En el caso de los frescos, si traspasamos estos efectos al estado de conservación, la suavidad del color posiblemente sea una causa, aunque ciertos especialistas hablan de la investigación de Piero por desarrollar un colorido intentando recoger con el mayor realismo posible, la atmósfera de las escenas ambientadas al aire libre.

En su obra teórica Sobre la perspectiva en pintura, Piero divide la pintura en tres campos: disegno, commensuratio y colorare (dibujo, proporciones y color). El primer libro analiza la proyección de superficies, el segundo la de los cuerpos geométricos, y el tercero la de los cuerpos complejos y los espacios. En este escrito el artista demuestra porque estaba interesado en la matemática. Ya que domina los conocimientos de perspectiva se puede permitir tomarse pequeñas licencias deliberadas en forma de errores, concebidos a propósito, para que no puedan ser detectadas a primera vista. De esta forma incita al espectador a hacer una lectura de su obra en profundidad y lo mantiene, al mismo tiempo, a una cierta distancia del discurso narrativo. La contemplación de sus pinturas origina un instante de desconcierto que incrementa la humildad y la atención espiritual. Simultáneamente podemos encontrar zonas inconclusas en obras de LeWitt que originan así una nueva figura. Queda a cargo del espectador completar o interpretar a su criterio la 
forma, similar a lo que advertimos en la serie Incomplete Open Cubes (19741982). Este momento desconcertante que buscaba Piero, en LeWitt produce una incomprensión enigmática.

En los frescos de la Iglesia de San Francesco de Arezzo, las diferentes escenas representan la dilatada historia de la Santa Cruz. Los episodios se basan el los textos de la Leyenda Áurea, recopilados por Jacopo de la Voragine entre 1224 y 1250 . Piero no ordena las escenas cronológicamente a diferencia de Giotto, sino que las agrupa de acuerdo a detalles formales que le permiten relacionarlas entre ellas. La ordenación no se presenta secuencialmente a medida que van sucediéndose los hechos, sino de manera simétrica, y la simetría se capta inmediatamente al entrar en la capilla. Este arreglo también lo encontramos en muchas disposiciones de los wall drawings de LeWitt cuando plantea un eje de simetría imaginario a partir del cuál sitúa los murales, generalmente confrontados, como en un efecto espejo. En Arezzo, los frescos están iluminados por la luz natural que proviene de la ventana central de la capilla, convirtiéndolos en un todo unitario. Las figuras siempre aparecen en una distancia similar y tienen proporciones también similares.

Esta composición permite, en concreto, contemplar las escenas de La Adoración de la Santa madera y Encuentro de Salomón con la Reina de Saba donde, si nos concentramos en el vestuario de las cortesanas de diferentes tonalidades (rojizos, rosados, verdes turquesa) asociamos, - una vez superada la distancia de los siglos - la coloración utilizada por el artista americano. Los colores cálidos se alternan en la obra de Piero con otros más fríos, en una gradación sumamente armoniosa. LeWitt se impregna y memoriza la paleta italiana que gradualmente irá depositando de nuevo sobre otras paredes contemporáneas. Coloraciones suaves y moderadas de amarillentos tenues, amarillos rosados, rosas pálidos, rojos mercurio, verdes semiclaros, turquesas muy claros, verdes ultramar, azulverdosos muy profundos, morados que irá aplicando y pasarán de ser paleta a ser carta de color, siguiendo un sistema de tratamiento del color mediante dilución de tintas acuosas que caracterizan su método antes de dar el salto hacia colores más sólidos.

LeWitt realiza un acto de concreción al ser capaz de destilar los conocimientos de estas dos figuras del Renacimiento y lo que supuso su visión, como "renacer" del concepto de arte y cambio sobre sus percepciones. Interpreta el pasado con las claves del pasado. Como constata en sus Sentencias sobre arte conceptual existe la mala costumbre de entender el arte antiguo desde las convenciones del presente y ello nos induce a errores de comprensión. 


\section{Mallarmé y el libro}

La pared se entiende como un espacio absoluto, lo mismo que las páginas de un libro. Uno es público y el otro es privado. Líneas, puntos, figuras, etc., se ubican en este espacio mediante el uso de las palabras. Las palabras son las vías que llevan a entender la ubicación de los puntos. Los puntos se verifican mediante las palabras. (LeWitt, 1996, p. 26).

Sol LeWitt establece un sistema lingüístico, un lenguaje artístico donde las palabras dan a entender la ubicación de los puntos y los puntos se confirman a través de las palabras. En el caso que expone, hemos de considerar los puntos como unidades lingüísticas no como unidades gráficas. En esta afirmación es la palabra la que marcaría el inicio. Mediante la palabra, el artista transcribe las órdenes a sus ayudantes. El mensaje artístico está contenido en unas instrucciones escritas. LeWitt piensa e indica lo que habrá que hacer: el artista concibe y planea el dibujo mural que realizarán los dibujantes. Concebir, planificar y dibujar son acciones ordenadas en la metodología del artista. Cada una de estas transiciones comporta diferentes posibilidades que son organizadas sistemáticamente.

El artista comenta también las aportaciones que en este sentido le ha reportado el estudio de la obra fotográfica de Eadweard Muybridge. Sus instantáneas descriptivas del movimiento humano y animal en sucesión rápida, le sugieren una posibilidad de hacer arte que no depende del momento, sino de una manera de proceder premeditada, consolidada, que da resultados interesantes y apasionantes. De igual modo que la narración de un hombre o un animal corriendo, también las combinaciones de una obra seriada actúan como una narración. Tanto Mallarmé desde la faceta de la escritura como Muybridge, desde la referencia visual, han contribuido a que LeWitt desarrolle una obra derivada de unas premisas elementales, una obra centrada en la noción de serie, como exploración de un orden de posibilidades en una secuencia lógica.

La recopilación de las ideas de Mallarmé sobre el libro y la palabra, acaece un puntal referencial para Sol LeWitt quien demuestra interesarse por la idea de seriación del poeta. LeWitt entiende las paredes como el espacio absoluto de las páginas del libro. Sus contribuciones en el ámbito del dibujo, del grabado y del libro de artista se acercan al microcosmos múltiple de Mallarmé, al 
plantearse el libro como un pequeño mundo regido por la relación universal: movimiento-espacio-tiempo. "El libro, expansión total de la letra, ha de extraer de ella, directamente, una movilidad; y espacioso, por correspondencias, instituir un juego, no se sabe cuál, que confirme la ficción" (Mallarmé, 2002, p. 90). El poeta dividía el libro en micro y macroestructuras, y la secuencia de actuación podía ser regulada por permutaciones dadas, dentro de las cuáles había unas áreas de libre elección. El espectador o lector está en posesión de las claves de la obra, por decirlo de alguna manera; aplicando las reglas del juego, simultánea o sucesivamente, abre la obra y construye una de sus posibles configuraciones.

Dar a la lectura la misma categoría que a la composición quería decir aceptar sus limitaciones naturales en la planificación compositiva: la pared dada por los dibujos murales, por ejemplo en Sol LeWitt. Si éste valora las irregularidades del soporte, imprevistas y azarosas consecuencias sobre el resultado final como parte integrante de la obra definitiva, Mallarmé cita un pensamiento similar en su relación con el impresor cuando encarga la maquetación de un poema:

Desearía unos caracteres bastante apretados, que se adaptasen a la condensación del verso, pero también aire entre los versos, espacio, a fin que destaquen bien unos de otros, lo que es necesario incluso con la condensación. He numerado los poemas. ¿Es útil? En cualquier caso, querría, también, un gran blanco después de cada uno, un descanso, ya que no han sido compuestos para sucederse así, y aunque, gracias al orden que ocupan, los primeros sirven de iniciadores a los últimos, desearía que no se leyese de una tirada y como buscando una ilación de estados del alma que resultasen unos de los otros, cosa que si no es así, dañará el placer particular de cada uno. (Mallarmé, 2002, p. 91).

Registros que pertenecen al mundo de la composición de textos que son imprescindibles en opinión de Mallarmé. Su obra no solo está formada por el sentido de las palabras sino también del efecto visual que estas palabras tendrán en la impresión definitiva. El carácter de la obra de Mallarmé también considera esta sintonía expresiva que en otro caso sería considerada como "detalles" delegables.

Este método de trabajo comienza a advertirse en LeWitt en Variaciones de cubos incompletos (1974). La serie se compone de 122 pequeñas estructuras incompletas de color blanco que desde una plataforma demasiado grande para 
ser captada de una sola mirada, nos sumergen en una experiencia obsesiva que nos obliga a ir eligiendo entre las figuras para detectar cuáles son las especificidades que las diferencian dentro de la serie. En opinión de Krauss se insertan en una retícula sin sentido que refleja una absurda obstinación. La experiencia de estas obras va exactamente en contra de lo que ella nombra "apariencia del pensamiento", sobre todo si entendemos el pensamiento como expresión clásica de la lógica.

Tal expresión, ya sea diagramática o sea simbólica, se basa precisamente en la capacidad de abreviar, de condensar, de tener capacidad para sugerir una expansión con dos o tres términos, de abarcar amplios espacios asimétricos con unas cuantas elipses, de utilizar en resumen la noción de etcétera. La charla de la expansión serial de LeWitt no tiene nada que ver con la economía del lenguaje matemático. (Krauss, 1996, p. 267).

H. R. Zeller sugiere que Mallarmé puede haber sido una de las fuentes más importantes para el posterior desarrollo del arte en dos y tres dimensiones de Sol LeWitt:

Conceptualmente proyectado y orgánicamente integrado que, en lugar de tomar como modelo ideas tradicionales de la forma escultórica o pictórica, emana las ideas de una estructura reglamentada antes de ser pintura, escultura o dibujo. Esta manera de abordar el objeto de arte tiene algunas correspondencias con el constructivismo, pero es más radical porque generaliza totalmente los elementos visuales implicados y no los usa sino después de contar con una estructura reglamentada antes de empezar. (Zeller, 1996).

Sin embargo, el proceso y la generación de las formas adquieren valor metalingüístico. Si consideramos la condensación de la palabra, de la idea y de la forma tienen mucho que ver con la proposición que el artista lleva a la visualización. En la lectura de Mallarmé se intuye el vacío sobre el papel como una posible obra de arte, idea sobre la cual el poeta no llega a ser consciente, pero en cambio LeWitt es capaz de percibir. Como señala Richard Wollheim (1996), Mallarmé describe una situación de pánico al iniciar el procedimiento de su tarea creativa. Su terror, el sentido de esterilidad que experimenta al sentarse ante su escritorio, al enfrentarse ante una hoja de papel en blanco donde se supone que ha de componer su poema y ninguna palabra acude a 
su mente. Podríamos preguntarnos parafraseando a Wollheim: ¿por qué Mallarmé, después de un lapso de tiempo, no se levantaba y presentaba la hoja en blanco como si fuese el poema que hubiese deseado escribir?

Realmente, nada resultaría más expresivo sobre los sentimientos de impotencia y devastación interior del poeta que el papel virgen. Para nosotros, el interés del citado gesto está, naturalmente, en que nos daría un ejemplo extremo del arte minimal o de un grado cero de la escritura. Ahora bien, existen muchas razones para no aceptar el vacío del papel como una obra de arte. El mismo LeWitt, como artista puente de la conceptualización minimalista, se sentiría identificado con la situación descrita. En el caso de sus primeros dibujos tal y como refleja en sus observaciones, se contempla un deseo de integración con el soporte, en el caso del muro, que le llevaría a suprimir cualquier intermediación y escoje dibujar directamente sobre éste para mantenerse más cercano a la bidimensionalidad el espacio circundante. ¿Cuántas veces se habrá encontrado LeWitt en una situación similar? El muro es el espacio de transferencia de la idea de página o lámina, es su particular tour de force con el ideal verificándolo desde la escala humana.

Retomando la sugerencia de Zeller, LeWitt no empieza antes de contar con una estructura reglamentada, refiriéndose también a una disposición mental ideada. Intentar establecer un paralelismo situacional o relacional entre la asociación del vacío del color blanco y la plenitud de contenido atribuible a otros colores, ratifica un binomio de ideas extremas situadas en relación. Nos aproximaría más, si cabe, a la evolución que llevamos observando en su obra, es decir, de las pequeñas estructuras tridimensionales seriadas, meticulosamente pintadas de blanco, a los dibujos murales como Whirls \& Twirls 1, la distancia nos aporta información sobre nuevos contenidos. El arco que trazan estas obras en el tiempo son los registros de su particular conquista del espacio.

La presentación de la hoja de papel en blanco de Mallarmé como si fuese el poema que hubiese querido escribir, podría tener su equivalencia en el campo del arte; no tanto en la producción de una tela en blanco, sino en algo más parecido a querer mostrar el contenido de un estudio vacío: "El espacio abierto, la página en blanco que atraerá tanto la decisión a favor del silencio como la necesidad de la escritura" (Mallarmé, 2002, p.19). Como apunta Mel Bochner (1996), las partes internas de un trabajo en sucesión ininterrumpida son una serie; la siguiente apreciación de Mallarmé ilustraría un poco más la suya propia: 
El poema se imprime, en este momento, tal como lo he concebido: en cuanto a la paginación es donde está todo el efecto. Una determinada palabra, en caracteres gruesos, para ella toda sola, pide toda una página en blanco y creo estar seguro del efecto... La constelación no afectará allá con leyes exactas, y tanto como se permite en un texto impreso, fatalmente un álbum de constelación. El barco escora, de lo alto de una página al bajo de otra, etc.; y aquí reside todo punto de vista (que tuve que omitir periódicamente), el ritmo de una frase en consonancia con un acto e incluso un objeto no tiene sentido si no los imita, y figurando sobre el papel, recogido de la estampa original por la letra sabe reproducir, a pesar de todo, alguna cosa. (Mallarmé, 2002, p. 91).

Este párrafo deviene la argumentación del destino en tanto que ubicación ideal de un poema, a la vez que se convierte en una figuración posible.

Las Sentencias sobre arte conceptual ya incluyen el procedimiento de la serie en la exposición de sus 35 pensamientos numerados intencionadamente, uno tras otro. Esta declaración constata en la asertación final que no se trata de arte, que solo son comentarios sobre arte y solo tienen sentido de esta manera. Cuando LeWitt expone "los juicios racionales repiten juicios racionales" entronca con Roman Jakobson. El método del encadenamiento viene dado por el desarrollo de la idea en que es más importante el "tiempo de enunciación" que el "tiempo enunciado". De aquí que las obras requieran una percepción lenta, una transcurso paralelo al que el autor sigue en su trabajo. Podríamos especular si no existe en LeWitt una doble intención y que el tiempo haga de estas propuestas un texto artístico, y a la manera de Mallarmé las palabras ejerzan los poderes mágicos del lenguaje. La conceptualización de ideas quiere ser una explicación en palabras sobre el pensamiento como universal. La crítica americana Suzy Gablik propone asimismo en su ensayo Progress in Art, que el arte abstracto se presenta como el fruto necesario de algún tipo de crecimiento intelectual universal (Gablik citada en Krauss, 1996, p. 262).

\section{El lenguaje abstracto: entre el enunciado y la síntesis}

La posición artística de LeWitt en la abstracción como medio y representación del lenguaje de su arte no se aleja del argumento que la convierte en un recurso favorable para organizar la diversidad de objetos expuestos a la percepción, la imaginación y al pensamiento. Tampoco de la consideración meditada en 
relación a los elementos metódicamente tratados desde el Trecento por Giotto y el Quattrocento por Piero en sus frescos; en el traslado de la secuencia poética hacia una ruptura o asunción de brecha en el hábito poético de Mallarmé; y en el poso o reinterpretación que de ellos recoge LeWitt en consonancia a sus intereses. Por lo que se hace patente que este recorrido sirve para testimoniar una dialéctica que pone de relieve que les une una sintaxis. En estos tres momentos están definiendo reglas para secuenciar su específica gramática, la de un lenguaje abstracto que más allá de expresar oraciones, piensa o imagina, coordina y ratifica conceptos.

Si la palabra inventa lo que nombra, Mallarmé quiso crear una palabra que reinventara o figurara lo nombrado. Así, si en una primera acepción "abstracción", en el sentido del término griego "aphairesis" designa el proceso mental tanto como el resultado; el hecho de aislar la atención del sujeto sobre aquello particular, no esencial, para centrarla en aquello general inevitable, esencial o primario. Un segundo concepto de abstracción se refleja en el término latín "abstrahere" que significa desvelar, retirar el recubrimiento y extraer una parte de este para un examen más profundo. En otras palabras, seleccionar un elemento o un componente de un dato aislándolo del resto.

En el contexto de la creación artística del siglo XIX se vincula la concepción original de la abstracción a una concentración de lo esencial. La psicología de la Gestalt explica la abstracción entre 1920 y 1930 como un proceso mental de repetición, observación y razonamiento que conduce del todo a las partes y de éstas al todo, a través de las relaciones internas, siendo un proceso fundamental de la actividad creativa. "Abstracción" era un término de taller de uso frecuente en Francia en 1880. Sucesivamente con el fauvismo y después el cubismo, el modelo de obra de arte a la que se podrá calificar de abstracta, empieza a imaginarse. En Alemania se dará una situación diferente. No será en los discursos de los críticos cuando se hablará de abstracción y de abstracto, pero sí a partir de su rica tradición estética, de la psicología experimental y del interés por la ornamentación (teorías de Worringer), como en el caso de Kandinsky. Worringer es el primero en captar las posibilidades de la abstracción como concepto estético, y el primero capaz de entrever un contenido posible en la forma abstracta. La aventura abstracta de las vanguardias descubre una pluralidad de intereses que se manifiesta desde la preocupación lingüística, — común a poetas y artistas-, que se explicitará en una constelación de autores que profundizarán en la creación de nuevos códigos, y en su traducción o traslación a modelos tanto formales como estéticos, en una voluntad de trascendencia de lo real. Algunas de la raíces de 
la abstracción se encuentran en una serie de cambios que se producen a finales del XIX. Para saber cómo funcionan los sistemas de gramática en la abstracción es preciso entender otros hechos acaecidos en el ámbito de la pintura, en el nombrado período del arte moderno. Línea y color seguían sometidos a los intereses de las artes decorativas a finales de siglo. El modelo del lenguaje poético y la música permitieron intuir formas de abstracción cuando ésta todavía no existía. En 1880 los simbolistas se lanzan a lo desconocido, casi iniciando la abstracción. ¿Cómo se produce el camino hacia la abstracción? ¿Cómo se pudieron imaginar, proyectar y después realizar "formas abstractas" cuando todavía no existían? Esta pregunta que siempre se manifiesta cuando indagamos en los inicios del arte, en qué momento, en qué situación, hace que no dejemos de observar los factores implicados con cierta estupefacción.

Es evidente que como en todo proceso de transformación, los cambios van alterando las circunstancias progresivamente y los mecanismos evolutivos necesitan su sedimentación. Parece que hubiesen sido necesarios patrones en los cuáles apoyarse para concebir una cosa radicalmente diferente de aquello que se había realizado hasta el momento. La música fue uno de estos modelos, y ligada a ella, el lenguaje. Pero sobre todo fue el lenguaje poético el que sirvió de pauta. La fascinación por el deslizamiento y desplazamiento de la función denotativa de las palabras hacia su fuerza expresiva y emocional intrínseca hacían de la poesía un lenguaje puro, y los primeros visionarios de la abstracción construyeron un arte "puro" en la acentuación de los medios pictóricos a través de líneas y colores. Una aventura que persigue una gramática de la creación nueva y distinta, y que dará lugar a poéticas tan diferentes como afines en su discurso como las de Kandinsky, Mondrian o Malevich entre otros. Las inquietudes por el lenguaje no eran ajenas al contexto, así Saussure plantea que "el signo lingüístico une no una cosa y un nombre, sino un concepto y una imagen acústica" es decir, respectivamente un significado y un significante. Las ideas de Saussure y Jakobson también traslucen en el pensamiento de Kandinsky, pero es imposible que hubiese leído a Saussure ya que el Curso de lingüistica no fue publicado hasta 1916, y no coincidieron con Jakobson en Moscú hasta el 1919. Estas asociaciones no hacen sino confirmar que ideas parecidas palpitaban en el ambiente.

Una de las fuentes del futurista Marinetti fue René Ghil, como también lo fueron Mayakovsky, Klébnikov y Kruchenik. Ghil escribió el Tratado del verbo (1886) y consideraba a Mallarmé su maestro antes de distanciarse de su ideario. De igual manera existía una consideración recíproca por parte de Mallarmé. Este último pone en evidencia la transformación que provoca el 
lenguaje poético en relación al objeto o al referente. Ghil especifica que en la función ordinaria del lenguaje representativo, la palabra, remite al objeto que se nombra. Jakobson sintetiza en una formula incisiva el lenguaje florido de Mallarmé: "Ninguna palabra poética tiene objeto. Es lo que pensaba el poeta francés cuando decía que la flor poética es la ausencia de todos los ramos". Jakobson emitía esta observacón en su primer texto del año 1919, en un artículo sobre el poeta Khlébnikov, uno de los principales protagonistas del futurismo ruso.

Para entender y ser capaz de hablar del lenguaje del color desde la teoría, el estudio de Chevreul revela hasta qué punto su contribución con De la loi du contraste simultané ha sido útil a abanderados del arte abstracto como Robert y Sonia Delaunay, Mihail Matiouchine, Georges Seurat, Johannes Itten y Josef Albers. Dicho estudio contiene las bases de la estructura de las relaciones puras de los colores y será reinterpretado en sucesivos momentos posteriores.

Después de 1945, sea en París o en Nueva York, la situación del arte se revela completamente diferente. Se acentúa un cambio perceptible en los años 30 cuando la importancia del arte abstracto va declaradamente en aumento. La abstracción geométrica es una corriente que crece, a pesar de los reproches que recibe por el dogmatismo de su posición y el riesgo de academicismo que implica. Las nuevas concepciones responderán a objetivos variados: proponer otras alternativas a la geometría en términos de definición, las referencias a la naturaleza, y la cuestión de la figuración están en el centro de los debates. Las determinaciones de los principales artistas han contribuido a establecer los diferentes sentidos que pueden darse al hecho de la abstracción. En mi opinión es un hecho artístico, un posicionamiento. ¿Qué entendían los precursores por arte abstracto? Quizás compartían la certeza que el arte abstracto es una alusión a la ausencia de representación. En la actualidad numerosos estudios confirman la diversidad de la naturaleza del arte abstracto, y la complejidad de esta observación son los múltiples aspectos que la abstracción toma en la obra de los artistas.

Desde las vanguardias, una de las principales cuestiones entorno a la cuál se articulará el discurso artístico será el análisis de la abstracción como una forma de lenguaje. Entre sus pretensiones estaba abandonar la figuración desvalorizando la formalización anterior, con la opción de crear otra realidad basada en el uso de las formas. La filosofía del lenguaje del formalismo ruso nutrió considerablemente toda la primera abstracción. En definitiva, desde la experiencia de las vanguardias se crea un espacio nuevo de investigación en 
función de los cambios que se están operando en la sociedad. La herencia de los formalistas rusos propicia un desarrollo en la abstracción muy asociado a los valores formales y estrechamente vinculado a los lingüísticos. Una voluntad investigadora orientada a cambiar las narrativas del arte precedente, es la conexión entre la vanguardia y la contemporaneidad que ha dado lugar a una longeva diseminación de producciones y variantes en el arte abstracto. En ese sentido, el siguiente fragmento de Ensayos de lingüistica general de Jakobson puede ser útil para ilustrarlo:

Puede ser que el impulso más fuerte hacia un cambio en la manera de aproximar el lenguaje y la lingüística fuese durante — para mí, al menos - el turbulento movimiento artístico de principios del siglo XX [...]. La capacidad extraordinaria de estos inventores (Picasso, Joyce, Braque, Stravinsky, Klébnikov, Le Corbusier) por rebasar sin tregua sus antiguos hábitos superados, como también su don sin precedentes por conseguir remodelar la tradición más antigua o cualquier otro modelo extranjero sin sacrificar su propia individualidad en la estupefaciente polifonía de creaciones siempre nuevas, estaban íntimamente ligadas a su sensibilidad única para conseguir la tensión dialéctica que existe entre las partes y el todo unificando, entre las partes conjugadas, sobre todo entre dos aspectos de todo signo artístico, el significado y el significante. (Jakobson, 1973).

Del mismo modo que en los primeros inicios hemos visto como se atribuyeron al lenguaje musical y al poético, estímulos detonantes del movimiento abstracto, consecutivamente éste adoptará usos de la lingüística y la semiótica visual a fin de poner en evidencia la naturaleza de los signos comunes al lenguaje y al arte. Cabe subrayar que desde 1945 los defensores de la abstracción hablan de "signos", parece ser la expresión más cualificada para referirlos. Signos de las emociones que experimenta el artista, signos que en el caso de Sol LeWitt se resolverían en una suerte de escritura espacial y que desde su pluralidad reemplazan y sustituyen la realidad ausente, signos del lenguaje personal de cada autor.

En los casos presentados se materializa en la realidad que nos transmiten los frescos del primer renacimiento italiano, coincide con los silencios de Mallarmé y toma nuevamente forma en el lenguaje conceptual de LeWitt. En cierto modo estos tres ciclos resultan integrarse en una estructura léxica intransferible a terceros, pero permutable entre ellos y el lenguaje abstracto. 
¿Por qué? Por la afinidad de su escritura espacial modelada por una dialéctica instaurada en la geometría, como medio de inscripción espacial. Por la voluntad de significar desde un código objetivo basado en el estudio, la medida y la proporción, una superficie sobre la cuál el color las hará tan presentes como tangibles. Aunque parece que sus significados se encierran en sí mismos y lo que podemos traducir es un modo de equivalencia posible en Mallarmé, una aproximación a modo de respuesta proposicional a la forma en LeWitt, cabe también enlazar todo ello con el secreto fondo verdadero de las pinturas murales del Quattrocento.

Desde otra posición bastante contrastada, durante los años 60 Claude LéviStrauss, padre de la antropología estructural, emprende una postura negativa contra el arte abstracto. Señala como defecto que el atributo esencial de la obra de arte es aportar una realidad de orden semántico. En este sentido, líneas y colores serían elementos que por ellos mismos no poseerían ninguna significación, pero sí serían los medios que permitirían expresar la significación de los objetos. En otras palabras, para reformular esta posición en términos de signos lingüísticos, las líneas y los colores serían puros significantes sin significados. Sobre esta tesis emitiría el veredicto Lévi-Strauss para condenar el arte abstracto, y más ampliamente el arte contemporáneo. Siguiendo su criterio, si no hubiese ninguna relación obvia entre la obra y el objeto que la ha motivado, no estaríamos ante una obra de arte, sino más bien ante un objeto de orden lingüístico. Una vez reducida a objeto lingüístico perdería toda la fuerza, a la vez que toda su capacidad de significar, de emocionar, de manera que no podríamos calificarla como obra de arte. Pero curiosamente, si Lévi-Strauss confirma que el signo lingüístico es autónomo en relación al objeto, dicha autonomía sería un despropósito para la obra de arte. ¿Por qué lo plantea de esta manera?

El academicismo del significado valida los objetos representados a través de una convención y de una tradición. El academicismo del significado, característico de las tentativas de los pintores abstractos donde cada uno intenta analizar su propio sistema, disolverlo, agotarlo totalmente y vaciarlo entonces de su función significativa, retirándole incluso la posibilidad de significar. (Strauss citado en Roque, 2003, p. 294).

La postura del más abstracto de los antropólogos siempre ha suscitado 
sorpresa en los artistas abstractos postestructuralistas, al descubrir qué arte es el que interesaba a Lévi-Strauss: un arte narrativo vinculado a corrientes figurativas del realismo fantástico, como se desvela en las entrevistas de Charbonnier (2005).

Entre estos parámetros se configura la diversidad de la tendencia hacia la síntesis: las formas y colores reemplazan el significado, es decir, el sujeto de la abstracción. Vemos como la relación del lenguaje con el arte abstracto se despliega continuamente en múltiples direcciones. Un hecho es considerar que las obras abstractas esten constituidas por signos y otra, examinar hasta qué punto el lenguaje verbal ha servido de modelo para pensar el arte abstracto. Sin embargo, esta cuestión es al igual que las líneas paralelas que discurren juntas pero discrepan en lo verbal o en lo visual.

\section{Conclusión}

La abstracción puede así aparecerse bajo el aspecto de un organismo hermético y un hecho lingüístico que no admite versiones ajenas a su orden estructural poético o formal. Podría decirse que se trata de una inflexible operación compositiva de un músico matemático.

La reflexión de LeWitt nos devuelve al objeto de inicio de este artículo y verifica como la descripción lingüística se acerca a una explicación sobre el arte abstracto:

El dibujante y la pared entablan un diálogo. El dibujante se aburre pero más adelante a través de esta actividad sin sentido encuentra paz o aflicción. Las líneas sobre la pared son el residuo de este proceso. Cada línea es igual de importante que las otras. Todas las líneas pasan a ser una sola cosa. El espectador de las líneas no ve nada más que las líneas sobre la pared. No tienen sentido. Esto es arte. (LeWitt, 1970).

Aún siendo así, la representación de esta futilidad de las líneas acoge tanto la univocidad del arte como una percepción de la libertad en su sentido más primordial. La lejanía cronológica entre los sujetos expuestos: Piero, Mallarmé y LeWitt no resulta fácilmente inteligible, no obstante durante el recorrido sugerido se hace patente cómo persiguen una forma de gramática organizativa, por pensar en tres prototipos de lenguaje en el arte regidos desde la premisa que todos sus elementos mantienen entre sí relaciones sistemáticas. Cabe 
mencionar que muestran una disposición mental estructurada ininterrumpida versus la indagación en el lenguaje plástico proclive a la abstracción geométrica.

En De quinque corporibus regularibus, Piero della Francesca no relacionó los cuerpos geométricos con determinados elementos sino que se limitó a estudiar las características matemático-geométricas de sus formas. El escrito destaca porque los cinco cuerpos regulares de la geometría: tetraedro, cubo, octaedro, dodecaedro e icosaedro se pueden incluir dentro de una esfera y porque no pueden simplificarse más. Los lados de estas figuras están formados por polígonos regulares. Los cubos, poliedros o bucles de Sol LeWitt ponen de relieve un interés compartido por su antecesor en la matemática que proyecta el espacio. En la escena pictórica desempeña un papel relevante desde el punto de vista formal: la aritmética y las mediciones eran dos conceptos de singular importancia. Al no exisitir ninguna unidad de medida unitaria, ni moneda, ni pesos ni tamaños constituyeron una necesidad. El contenido de cualquier recipiente debía calcularse por sí mismo, de manera que la capacidad de cálculo tenía que ejercitarse continuamente. Se recurría para ello a dividir imaginariamente los objetos en cilindros, círculos y otras formas geométricas similares. Se entiende así que los artistas recurriesen a un repertorio compositivo estandarizado, ya que determinadas formas permitían al espectador poco ejercitado en las matemáticas captar el espacio.

La pintura equivalía a una leyenda sin palabras, ilustrativa de un mensaje. Dicha categoría narrativa no se hará presente en LeWitt, pero paulatinamente la instalación de sus murales en lugares vividos, pintados anteriormente, con un valor de escala humana completamente opuesto a la geografía americana conformarán su manera de abarcar el espacio. Perseguirá una experiencia similar a la de sus antecesores y conseguirá autocontemplarse en esa dimensión. La naturaleza del muro, el significado del fresco en la tradición renacentista, la luz y su color, se transforman en más que factores de atracción para Sol LeWitt: intervienen en su percepción modificando la manera de entender sus propias convenciones. Si tradicionalmente en el Renacimiento temprano el color se utilizaba para la construcción geométrica y para crear efectos de profundidad, a través de las relaciones estipuladas entre los diferentes valores cromáticos se podía determinar la situación de un cuerpo o de una superficie. LeWitt siguiendo su premisa que "la percepción de ideas conduce a nuevas ideas" aporta con su criterio una predisposición a imaginar otros resultados para aspectos colorísticos donde dibujo y color se conciben continuos.

Si para Mallarmé la certidumbre del hallazgo de una nueva dimensión poética, significa la apertura hacia el espacio contemporáneo, la poesía como lenguaje puro y directo puede reflejarse en la síntesis que proyecta la geometría. 
El germen de la página es el contenedor de la posibilidad, del impulso estimulante, de la multiplicidad de perspectivas poéticas en su sentido más universal. La página de LeWitt enlaza su discurso en una extensión constelada de formas y colores profundamente analizado en su recorrido serial.

El wall drawing Whirls and Twirls 1 de la Sala de Lectura Panizzi funciona como catalizador, como un haz de posibles significaciones que induce al lector a la libertad interpretativa. El deseo de integración en el caso del muro como soporte que registrará eventualmente su obra de manera perecedera, lleva a Sol LeWitt a eliminar intermediarios y a elegir dibujar directamente sobre éste para acercarse a la bidimensionalidad del espacio circundante. Cuando las intervenciones se realizan en paredes alzadas en territorio italiano es inevitable que la emulación de sus antecesores, adscritos a su memoria pictórica adquirida en sus estancias en Italia, no trasluzca. Su bagaje se hace presente, como su disfrute por la neutralidad que caracteriza los espacios públicos seleccionados, siendo cómplice al capturar nuevamente al observador. La pared y la página se confirman como el "espacio absoluto" donde compartir su experiencia con el espectador.

\section{Referencias}

Bochner, M. (1996). Arte en serie. En Minimal Art (pp. 83-87). Donostia, Koldo Mitxelena Kulturenea. Diputación Foral de Guipuzkoa.

Charbonnier, G. \& Lévi-Strauss, C. (2005). Entrevistas con Claude LéviStrauss. Madrid, Amorrortu Editores España SL.

Deleuze, G. (2002). Diferencia y repetición. Buenos Aires, Amorrurtu editores.

García, A., LeWitt, S., Miller-Keller, A. \& Rose, B. (1996). Sol LeWitt.

Dibujos murales. Wall Drawings. Madrid, Sala de las Alhajas. Caja de Madrid.

Jakobson, R. (1973). Essais de linguistique générale 2. Rapports internes et externes du langage. Paris, Éditions du Minuit.

Judd, D. (1991). Écrits 1963-1990. Paris, Daniel Lelong éditeur.

Krauss, R. E. (1996). La originalidad de la vanguardia y otros mitos modernos. Madrid, Alianza Forma. Alianza editorial, S.A.

Laskowski, B. (2000). Piero della Francesca. Köln, Könemann Verlagsgesellschaft. 
LeWitt, S. (1970, abril 6). El dibujante y la pared. En "Wall Drawings", Arts Magazine, 44. New York.

LeWitt, S. \& Miller-Keller, A. (1994). Sol LeWitt Critical Texts. Roma, I libri di AEIOU.

Mallarmé, S. (2002). Fragmentos sobre el libro. Murcia, Colección de Arqui-lectura $n^{\circ} 39$. Colegio de Aparejadores y Arquitectos técnicos de la región de Murcia.

Montolío, C. (1996, marzo). Sol LeWitt, la lógica de la brevedad y el orden de lo efímero. Una especial forma de pintar las paredes con fórmulas de matemática belleza. Revista Internacional de Arte LÁPIZ 120. Año XV.

Publicaciones de Estética y Pensamiento, S.L. 48-55.

Roque, Georges (2003). Qu'est-ce que l'art abstrait? Une histoire de

l'abstraction en peinture (1860-1960). Paris, Éditions Gallimard.

Collection Folio Essais.

Wollheim, R. (1996). Minimal Art. En Minimal Art (pp. 23-31). Donostia, Koldo Mitxelena Kulturenea. Diputación Foral de Guipuzkoa. Zeller, H. R.(1980/1978). Mallarmé and Serialist Thought. En Sol LeWitt. New York, The Museum of Modern Art.

Eugènia Agustí: Doctora y profesora del departamento de Pintura de la Universidad de Barcelona.

Contact Address: Facultad de Bellas Artes. Universidad de Barcelona. Departamento de Pintura. c/ Pau Gargallo 4, 08028 Barcelona (España). E-mail address: euagusti@ub.edu 
Instructions for authors, subscriptions and further details:

http://brac.hipatiapress.com

\section{Dibuixar un arbre d'Àlex Nogué}

\section{Rosa Pera Roca ${ }^{1}$}

1) Curadora Independent. Espanya

Date of publication: June $3^{\text {rd }}, 2014$

Edition period: February 2014-June 2014

To cite this article: Pera, R., (2014). Recensión del libro Dibuixar un arbre (Review of the book). Barcelona, Research, Art, Creation, 2(2), 248-251. doi: 10.4471/brac.2014.11

To link this article: http://dx.doi.org/10.447/brac.2014.11

\section{PLEASE SCROLL DOWN FOR ARTICLE}

The terms and conditions of use, except where otherwise noted, are related to the Open Journal System and to Creative Commons Attribution License (CCBY). The indication must be expressly stated when necessary. 
BRAC - Barcelona Research Art Creation. Vol. 2 No. 2, June 2014, pp. 248-251

\section{Reviews (I)}

\section{Dibuixar un arbre d'Àlex Nogué}

El text és un abstracte de la meva aportació a la presentació del llibre Dibuixar un arbre/Drawing a tree. Barcelona, 2013. Editorial Comanegra Català/anglès, 180 pàgines. Color ISBN: 978-84-15097-91-4 a la seu de l'editorial el 21 d'octubre de 2013. El llibre, liderat per l'artista Àlex Nogué, és una munió d'escrits en torn de la seva pràctica artística, amb reflexions fetes des de la filosofia, la docència, la creació, la poesia i l'anàlisi de l'art contemporani. Hi hem participat Eudald Camps, Xavier Franquesa, Angels Viladomiu, Victor Sunyol i jo mateixa.

He llegit el llibre de l'Àlex Nogué i he après coses noves i d'altres que no sabia que havia oblidat.

Conèixer no és el mateix que pensar: ho diu Jorge Wagensberg (2013), per qui coneixement és pensament simplificat, codificat i empaquetat, llest per sortir de la ment, atravessar la realitat i ensopegar-se amb una altra ment que el descodifiqui. Afegeix que existeixen tres mètodes i formes de coneixement: el científic, l'artístic i allò revelat.

Hi ha coses que hem vist repetidament, però que mai hem mirat amb atenció. De sobte, per un esllevisament de sentit, se'ns revelen com quelcom nou. Restaven ocultes, en algún lloc del pensament, en algun lloc del temps, o en ambdós alhora. Rescatar-les és un repte, a cops un plaer, de vegades dolorós. Si hem de triar un símbol de l'impertèrrit, és l'arbre; càpsula de temps viva, n'atresora invisible el registre. Decidir dibuixar un arbre a escala real és desafiar el temps.

Marcel Proust, el gran mestre de l'ocultament disseccionat per Maurice 


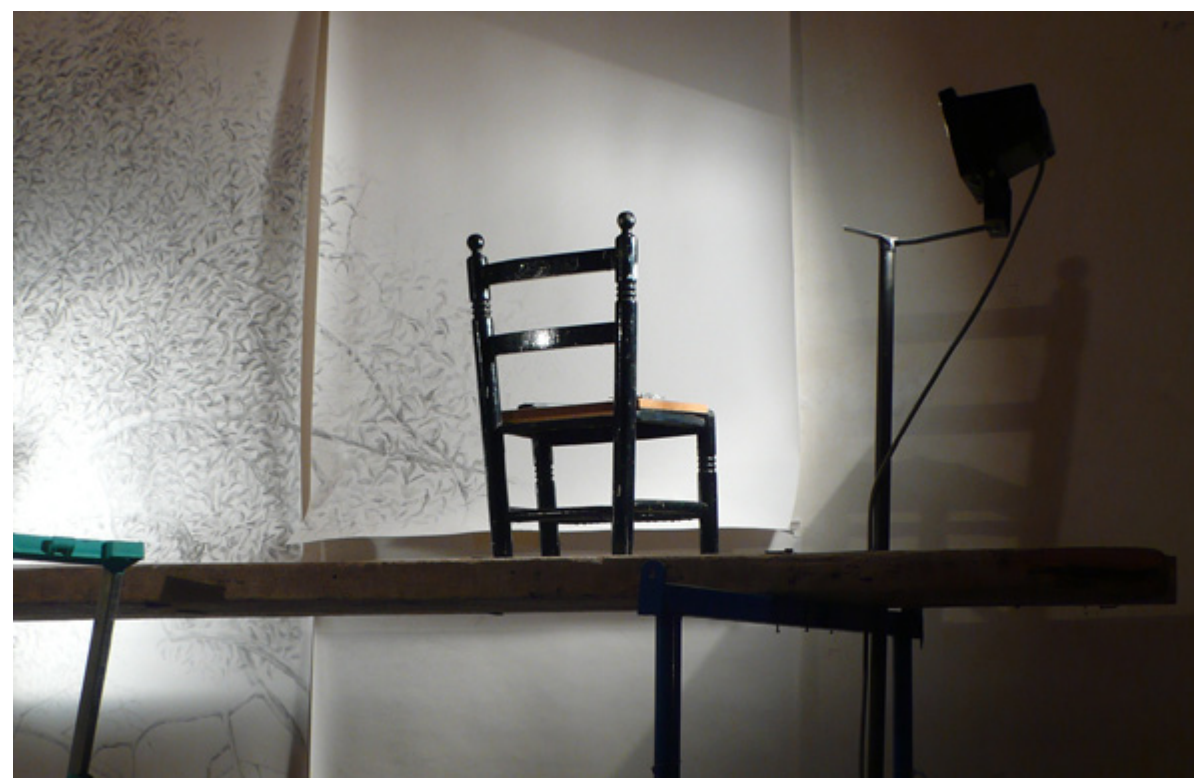

Figure 1. Dibuixar un arbre. Àlex Nogué. Imatge de l'autor. (C)

Blanchot (1995), és navegant avesat a entretelar irrealitat $i$ vida real en accedir a allò fabulós a través dels avatars quotidians. Ho fa mitjançant "una complicació potser enganyosa, però meravellosa" de totes les formes de temps. Així, "el temps destructor" o el "temps esborrat pel temps mateix" que paradoxalment dóna pas a experimentar "una mica de temps en estat pur" per "viure l'abolició del temps": "l'èxtasi del temps". El temps com espai buit, lliure. Temps pur: el temps en l'espai imaginari, el de l'art.

Experimentar. "Entrar en un dibuix és com entrar dins d'un núvol. Vistos de lluny els núvols tenen un contorn definit. Viscuts de prop experimentem que no tenen perfil i que no hi ha cap lloc concret que ens indiqui el moment de pas de 1'exterior a l'interior" (Nogué, 2013). "És una línia difusa”, explica Nogué, “com les imatges dels límits en les pel·lícules d'Angelopoulos. És de manera progressiva com les formes es fan difuses i en perdem la visió nítida. Una situació que té menys a veure amb un estat d'ànim indecís i més a veure amb un estat d'ànim complex". No puc més que recordar aquella "complicació enganyosa" que adivina Blanchot a l'escriptura que arrossega a espais ocults d'emoció i estranyesa de Proust. I penso que l'Àlex Nogué ha estat tocat per "l'èxtasi del temps" i que per això els seus dibuixos d'arbres grans i magnífics, 
250 Rosa Pera-Dibuixar un arbre d'Àlex Nogué

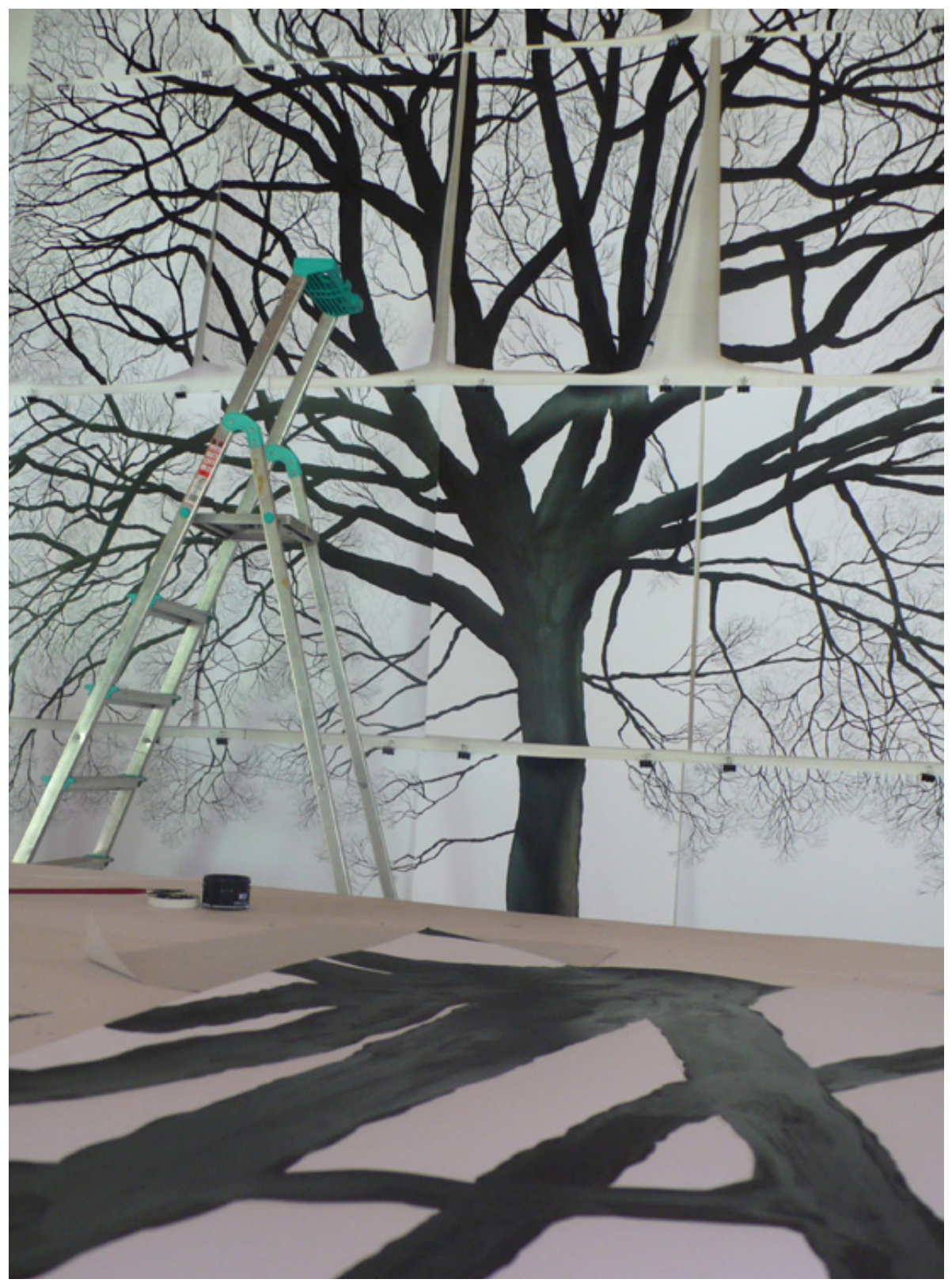

Figure 2. Dibuixar un arbre. Àlex Nogué. Imatge de l'autor. (C) 
delicats i torbadors alhora, poden atraure i engoixar a parts iguals en un instant de coneixement. És el temps de l'art.

Sabut és que l'art no consisteix en un mer mirar l'objecte per representar-lo. És quelcom més complicat. On rau, però, la complexitat? Potser dibuixar un arbre sigui una de les maneres possibles d'anar al moll de l'òs. Al núvol de Nogué s'amaga l'esfera densa de l'aprenentatge que retorna imatges i desitjos, en un diàleg intens i no sempre plàcid entre ment, ma, emoció, l'objecte (l'arbre) i qui llegeix el dibuix.

El dibuix com a temps perdut imprescindible per assolir el temps recobrat, en línies de temps que com diu Deleuze (1970), són "veritables línies d'aprenentatge".

Oportuna, l'evocació del preludi de L'eternitat $i$ un dia (Mia aioniotita kai mia mera. Théo Angelopoulos, 1998): "Diu el meu avi que el temps és un nen que juga a les bales". L'infant que aprèn perdent el temps, inadvertidament, cercant la posició òptima per esbossar les línies d'impacte perfectes. Un instant privilegiat que rememora el protagonista, precisament un escriptor, en boca del seu avi, quan ell mateix és ja un home madur, i en els darrers dies de vida vol transmetre coneixement al nen de futur incert i perillós que l'escolta, com ell, atemorit per l'esdevenir.

Prendre posició, a cada moment i a consciència: la millor brújola per circular pels camins de l'aprenentatge, de la vida. Amb l'experiència de la pràctica de l'art, no fos cas ens n'oblidéssim.

Rosa Pera. Curadora i investigadora d'art i cultura contemporànies rosapera@gmail.com

\section{References}

Blanchot, M. (1995). El libro por venir. Madrid: Ed. Trotta, 31-32.

Deleuze, G. (1970). Proust y los signos. Barcelona: Anagrama, 35.

Nogué, Àlex. (2013) Dibuixar un arbre / Drawing a tree. Barcelona: Ed. Comanegra, 86.

Wagensberg, J. (2013). El mapa del conocimiento. La Maleta de Porbou $n^{o}$ 1, p. 12. 